العوامل الذاتية والأسرية لاى المراهقين الموهوبين المترددين على بعض قصور الثقافة بالإسكندربة وتأثيرها على درجة موهبتهم وسماتهم الثخصية

$$
\text { نيفين مصطفى حافظ' '، مواهب إبراهيم عياد '، أحمد سمير أبو دنيا'و ناهد محمد الرحماني' }
$$

في الدراسة 9 1.4ه \% لايهم شعور بالإحباطات الثخصية بدرجة

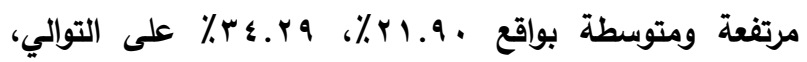

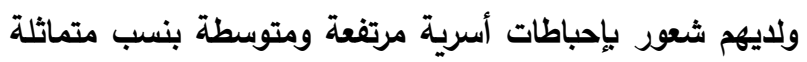

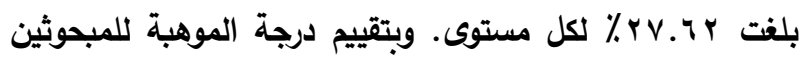

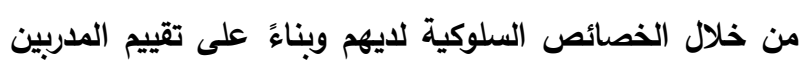

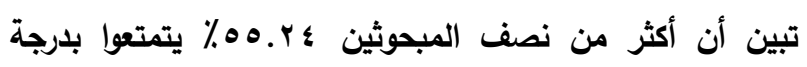

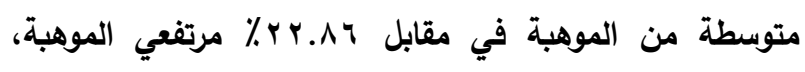

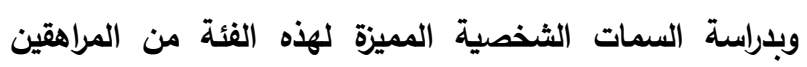

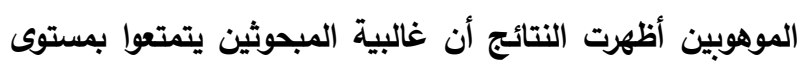

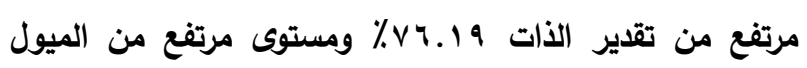

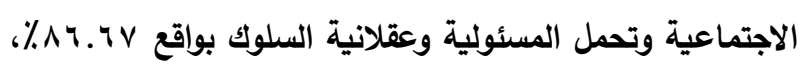

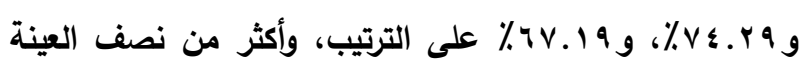

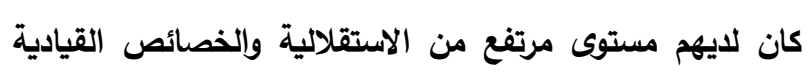

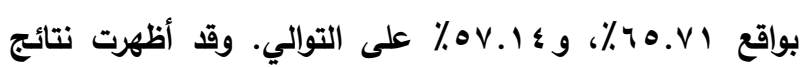
تحليل الانحدار المتعدد أنه من بين المتغيرات الذاتية (الثخصية)

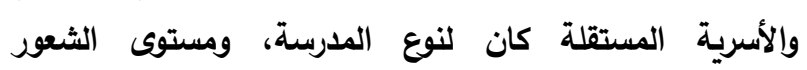

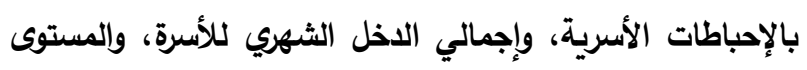

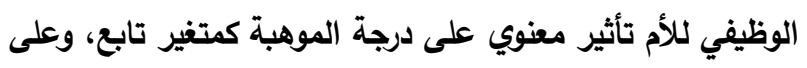

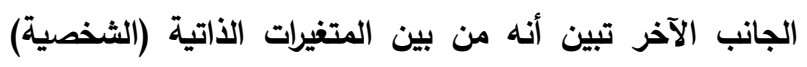

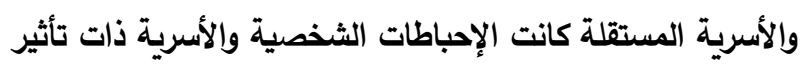
متوي على درجة السمات الثخصية للمبحوثين كمتغير تابع.

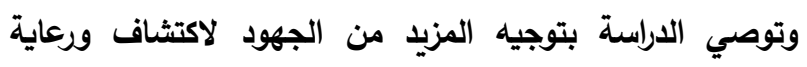

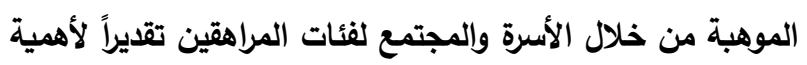

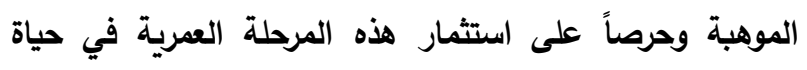
النشء.

الكلمات المفتاحية: الموهوبون - المراهقون - قصور الثقافة - تنمية ورعاية الموهبة

$$
\text { الملخص العربى }
$$

تنبع الثروة الحقيقية للأمم من قدرتها على تنمية الاستعادات الفطرية لأبنائها والاستفادة منهم بصورة مستمرة،

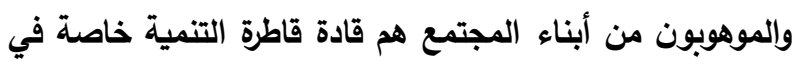

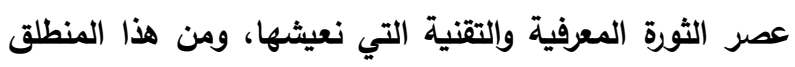
يهذف هذا البحث بصفة رئيسية إلى دراسة العوامل الذاتية التئية

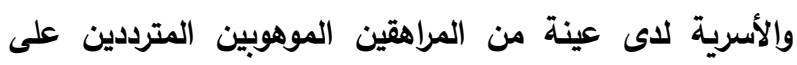
بعض قصور الثقافة بالإسكندرية وتأثيرها على درجة العندين موهبتهم وسماتهم الثخصية، ولتحقيق هذا الهذف تم استخدام استمارة استبيان للتعرف على العوامل الذاتية (الثخصية) والأسرية لهنية

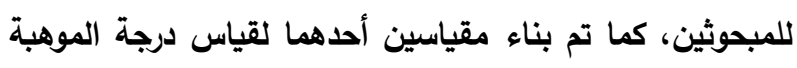

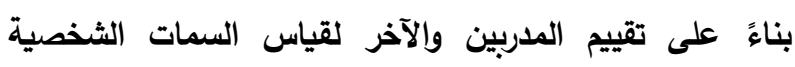
المميزة للمبحوثين. تضمنت عينة الدارسة قصري ثقافة الأنفوشي والثاطبي حيث تم اختيار عينة من المراهقين الموهوبين

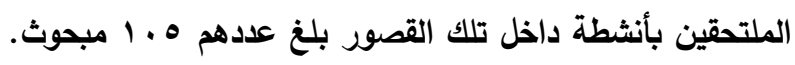

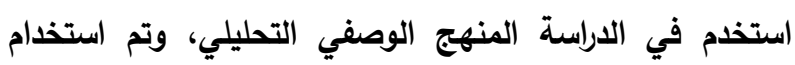
برنامج SPSS الإصدار ب r إلجراء المعاملات الإحصائية. وقد بينت النتائج أن ما يقرب من ثلثي الموهوبين المترددين

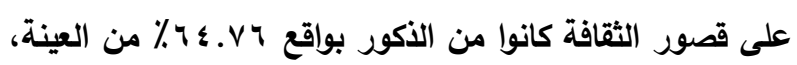

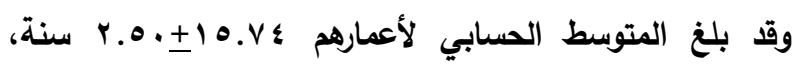

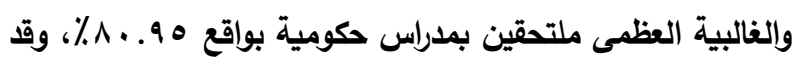

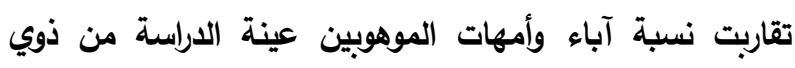

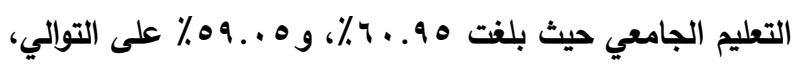

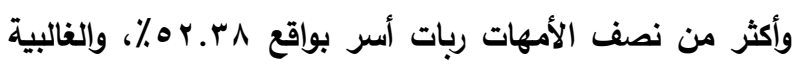
العظمى من أسر المبحوثين كان مستوى مساهماتهم الأسرية

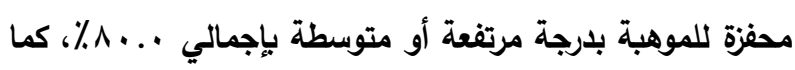

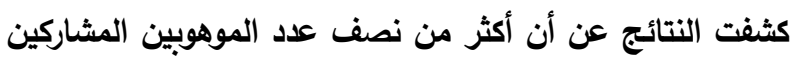




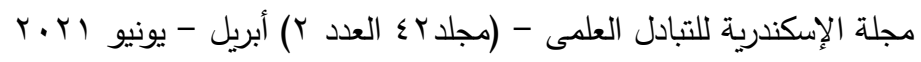

$$
\text { المرحلة (WHO,2020). }
$$

وتسهم العديد من الجمعيات والمؤسسات العلمية والوطنية والدولية في دفع عجلة الاهتمام بفئة الموهوبين من أبناء المجتمع إلى الأمام، ويعد اشتراك المراهقين في منظمات أو لهوله جمعيات أو مؤسسات ثقافية نافذة تتيح لهم مميزات عديدة

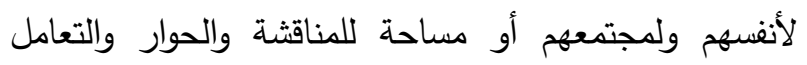
الفعال مع القضايا الخاصة التي تهمهم، وكونهم جزء من عمل جماعي فهذه المؤسسات توفر لهم منبراً يمكن أن يساعدهم على تطوير المهارات الثخصية والاجتماعية

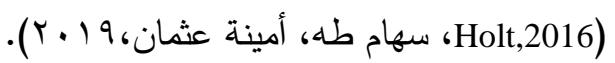

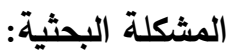

يعد الاهتمام بالموهوبين من المراهقين هدفاً أساسياً ينادى

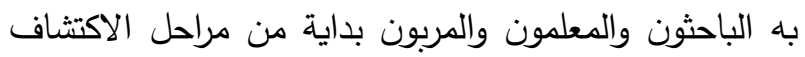
المبكر لمواهبهم وقدراتهم، والتعرف على خصائصهم ثم العمل على تتمية هذه المواهب والقدرات عن طريق التعليم والتدريب الموجه. وينبغي أن ينصب هذا الاهتمام على جانبين أولهما البيئة المحيطة بالموهوب بمفهومها الواسع الذي يشمل البيئة

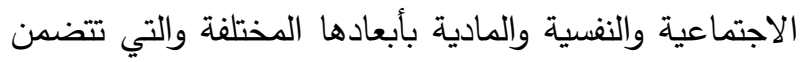
الأسرة والمدرسة والمجتمع بمؤسساته المتعددة، وثانيهما الفرد باعتباره محور الاهتمام الأساسي في التتمية (عاصم

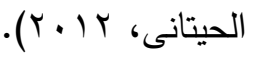

فالهدف من تتمية فئة المراهقين هو الإعداد الجاد لهم من قبل المجتمع، والذي يتضمن عمل خطط وبرامج وفقاً لمعايير عصرية وتحت إشراف طواقم مؤهلة لإكسابهم الوعى والإعداد الكافيين وأيضاً بنشر المعرفة لتمية معلوماتهم الاجتماعية والاقتصادية والثقافية، وتعريفهم بالمشكلات العالمية، كما يجب أن يهتم المجتمع بجذبهم نحو ساحة العمل مع مراعاة طموحاتهم ورغباتهم المستقبلية، وعلى المجتمع أن يستجمع طاقاته ويوحدها نحو الأولويات، ويعزز قيم التعاون والتسامح بينهم وأن يمكنه من استثمار وقت الفراغ في جوانب عديدة من الأنشطة الثقافية والرياضية والتي

\section{المقدمة}

إن رعاية الموهوبين والاهتمام بمجالات تقوقهم وموهبتهم تعد مظهراً من مظاهر تصنيف العالم المتقدم

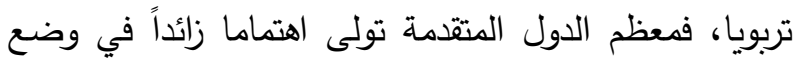
البرامج والإستراتيجيات الخاصة برعاية الأفراد الموهوبين لما يتوافر لاى هذه الفئة من قدرات وإمكانيات يمكن الاعتماد

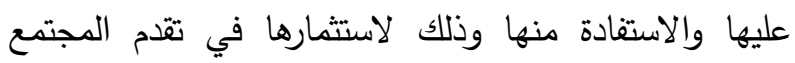
والارتقاء به ليواكب عجلة التطور والحداثة (حابس العواملة، r ا • Y)، والموهبة ليست ثابتة أو مطلقة، فيمكن أن يكون الإنسان موهوباً ولا تتوافر الظروف المناسبة لبروز موهبته على أرض الواقع مع الأخذ بالاعتبار أن الأطفال الموهوبين

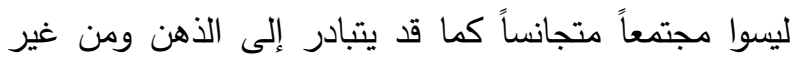
المتوقع أن يُظهر الأطفال الموهوبين كل الخصائص وفي جميع المجالات، لكن كلما ازدادت درجة الموهبة عند الفرد ارتفعت درجة تفرده عن غيره، فخصائص الموهوبين ليست ثابتة أو جامدة لكنها متغيرة وتعتمد على التغيرات داخل الفرد وتفاعله مع البيئة المحيطة، مما يفسر ظهور الموهبة لدى بعض الأطفال في مراحل مبكرة من نموهم وآخرين تظهر لديهم الموهبة في مراحل متأخرة تبعاً للرعاية التي توفرها لهم

$$
\text { بيئاتهم (فتحي جروان، (Y. • (Y). }
$$

وتحتاج فئة الموهوبين إلى عناية ورعاية خاصة، إذ أن رعايتهم وتقديرهم صار ضرورة حتمية مهمة من استراتيجيات التتشئة في المجتمعات العربية، فهم يثكلون ثروة حقيقية خاصة في عصر العولمة والانفجار المعرفي والمعلوماتي والزخم الهائل للتقنية، فالموهوبون هم قادة قاطرة التتمية في مجتمعاتهم (سهام طه، أمينة عثمان،9 ( ب ب). وللموهبة في مرحلة المراهقة أهمية خاصة، إذ تعد مرحلة المراهقة فترة حاسمة لتطوير العادات الاجتماعية والعاطفية المهمة للسلامة النفية، والحفاظ عليها، وقد أكدت العديد من وند البحوث والدراسات النفية أهمية ممارسة المراهقين للأنشطة لما لها من تأثير إيجابي على تطورهم النفسي إبان تلك 
جهودها مع الددرسة والمجتمع لتتكون شخصيته مما يؤهله للتكيف والنبوغ. في ضوء ما سبق يصبح من الضروري دراسة دور الأسرة والمؤسسات الثقافية بالمجتمع في تتمية القدرات والمهارات الخاصة بالموهوبين من المراهقين المترددين على الهي المؤسسات الثقافية، وكذلك الطرق والأساليب التي يمكن استخدامها للتعرف على هذه الفئات والإستراتيجيات المناسبة والمطبقة لرعايتهم، والتعرف على مشاكلهم الأسرية والمدرسية والمجتمعية مما يساعد في تتمية قدراتهم ومهاراتهم والتغلب على ما يواجهونه من عقبات من جانب وتقييم الخدمات

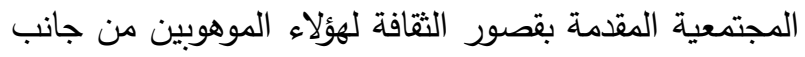

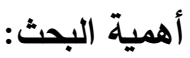

الأهمية العلمية: - المئه

يعد هذا البحث إضافة علمية في مجال الاقتصاد المنزلي عامةً وموضوع تتمية ورعاية الموهوبين خاصةً.

\section{الأهمية التطبيقية:}

ا. يساهم في خلق مجتمع واع بأهمية اكتثاف المواهب

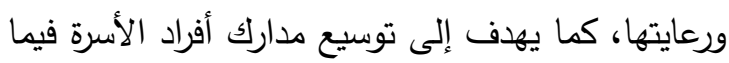

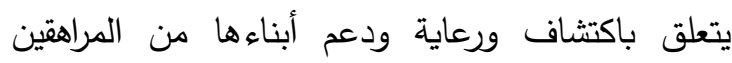

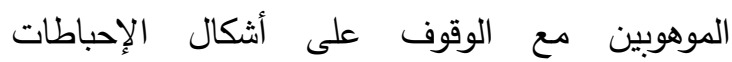

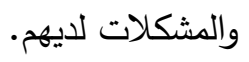

r. اكتثاف وتحديد مجموعة العوامل الذاتية (الثخصية) ذات التأثير على مستوى الموهبة لدى المراهقين للعمل

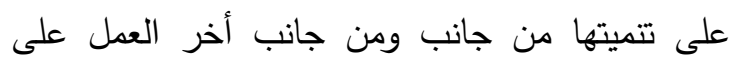

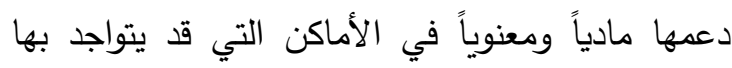
هؤلاء الموهوبين داخل أو خارج المنزل.

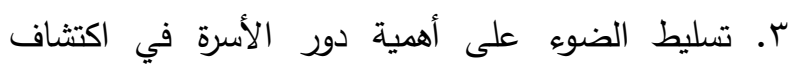
ورعاية الموهوبين.
ينعكس تأثيرها على انتمائهم وتبعدهم عن الانحراف خاصة إذا مارسوها داخل المؤسسات التربوية والثقافية (عبد الله

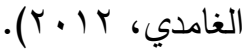

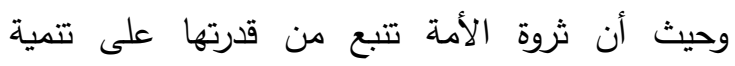
الاستعدادات الفطرية لأبنائها والاستفادة منها بصورة مستمرة ونحن نعيش اليوم عصر علم وفكر وإبداع، عصر يتسم بالتطور السريع، عصر تعد فيه القوى البشرية من أهم عوامل

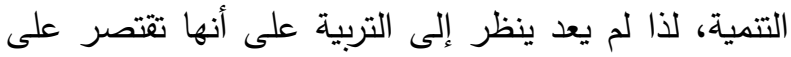
جانب معين من جوانب النمو وإنما هي تربية مستمرة متكاملة، والنشاط التزبوي الحر أحد روافدها ومقوماتها (عبد

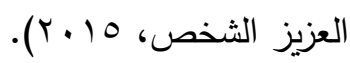

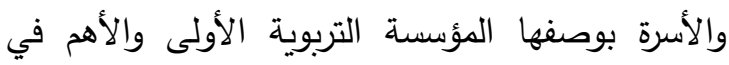
حياة الموهوب حيث يعتبر الوالدين مصدر المعلومات لابنهما الموهوب نظراً لملاحظتهما له منذ ولادته وعبر مراحله العمرية، فيلاحظان تطوراته، واهتماماته وهواياته ومختلف إنجازاته التي تعكس تميزه عمن هم في مثل سنها، وكذلك

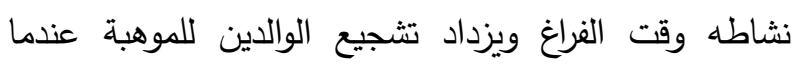
يكون لديهم خلفيه ثقافية وعلى وعى وثقافة بماهية الموهبة

$$
\text { (مصطفى القشش، (1) - (Y). }
$$

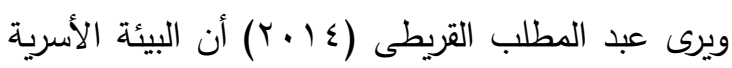

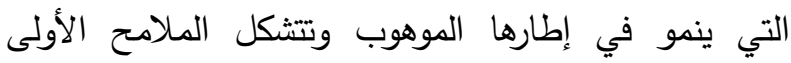
لثخصيته وخاصة في المراحل المبكرة من عمره تعتبر مصدر لإثباع حاجاته واستثارة طاقاته وتنميتها، وهذا من

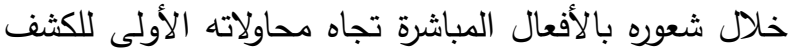
والتجريب، وتجاه خروجه على القوالب النمطية المألوفة لمتنكير كما تؤكد فتحية مقحوت (ع ا بr) أن ما يعزز التتمية والتطور لاى الموهوب وخاصة في مرحلة المراهقة هو التتشئة الأسرية الإيجابية حيث أنها مرحلة ييرز فيها إمكانات العراهق العقلية والانفعالية والاجتماعية بقدر رعاية الأسرة

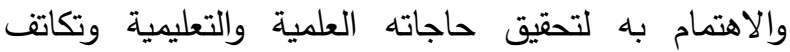




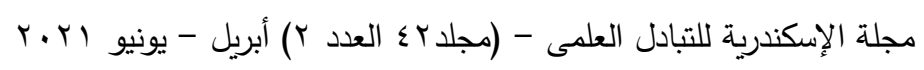

وغيرها في مختلف المحافظات (الهيئة العامة لقصور

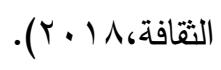

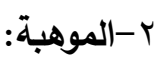

عرف ممدوح الكناني (11 + (Y) الموهبة على أنها القدرة التي تجعل أداء الأفراد فوق المتوسط، ويكون أداءً متميزاً في مجال أو أكثر من مجالات النشاط الإنساني ووجود مجال التفوق العقلي والأكاديمي والعلمي والفني والقيادي....

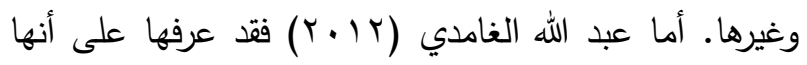
مهارة يتقنها الطالب بغض النظر عن مستواه الدراسي. كما تعرف الموهبة بأنها القدرة التي تجعل الفرد عند

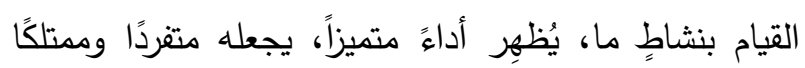

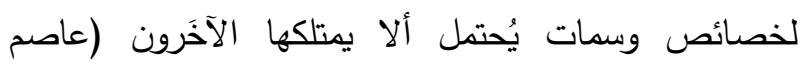

$$
\text { الحيتاني، ب ( • (ب). }
$$

ولقد تم تبني هذا التعريف كتعريف إجرائي في هذا البحث.

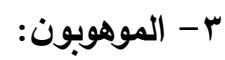

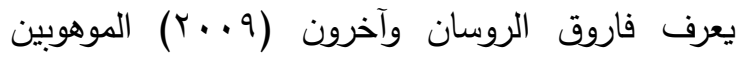
بأنهم الأفراد اللذين يظهرون أداء متميزاً مقارنة مع المجموعة العمرية التي ينتمون إليها في واحدة أو أكثر من القدرات الآتية: القدرة العقلية، والقدرة الإبداعية في مجال أو أكثر، التهن والقدرة على التحصيل العلمي المتميز، والقدرة على القيام بمهارات متميزة كالمهارات الفنية والرياضية واللغوية ...الخ، والقدرة على المثابرة والالتزام والقوة الدافعة العالية والمرونة والاستقلالية في التفكير كسمات شخصية وعقلية بالإضافة لخصائص وجدانية وجسمانية ملحوظة من جانب المحيطين

$$
\text { بهم والقائمين على رعايتهم. }
$$

ويعرفهم فتحي جروان (Y.Y.Y) بأنهم الأفراد اللذين يعطون دليلاً على اقتدارهم على الأداء الرفيع في الدجالات العقلية والإبداعية والقيادية والأكاديمية الخاصة ويحتاجون لخدمات وأنشطة لا تقدمها المدرسة عادة وذلك من أجل ولإنل التطوير الكامل لمثل هذه الاستعدادات والقابليات وهم أولئك الأين يتم التعرف عليهم من قبل أشخاص مؤهلين.
ء. كما يهتم البحث بلفت نظر المتخصصين والمهتمين لأهمية دور بعض المؤسسات الثقافية في المجتمع نحو فئة الموهوبين وأهمية تلبية احتياجاتهم.

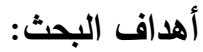
يهدف البحث بصفة رئيسية إلى دراسة العوامل الذاتية والأسرية لدى عينة من المراهقين الموهوبين المترددين على إلى دلى بعض قصور الثقافة بالإسكندرية وتأثيرها على درجة موهبتهم وسماتهم الثخصية. ولتحقيق ذلك تمت دراسة الأهداف الفرعية التالية: 1. الكشف عن الخصائص الذاتية (الثخصية) والأسرية لدى عينة من المراهقين الموهوبين المترددين على بعض عن المن قصور الثقافة بالإسكندرية. ץ. تحديد مستوى درجة الموهبة لدى عينة المراهقين الموهوبين بناءً على تقييم مدربي الأنشطة بقصور الثقافة موضع الدراسة. r. دراسة السمات الثخصية المميزة للمراهقين الموهوبين موضع الدراسة. ء. تحديد العوامل الذاتية والأسرية (كمتغيرات مستقلة) المؤثرة على كل من مستوى درجة الموهبة ومستوى سمات الشخصية (كمتغيرات تابعة) لدى عينة البحث من المراهقين الموهوبين المترددين على بعض قصور الثقافة بالإسكندرية. الأسلوب البحثي أولاً: المصطلحات العلمية والمفاهيم الإجرائية. 1-قصور الثقافة: - 1 - 1 هي إحدى المؤسسات المجتمعية للدولة التي أنشئت وفقاً لقرار رئيس جمهورية مصر العربية رقم سج لسنة 1919 بإنشاء " الهيئة العامة لقصور الثقافة" التي تتبع وزارة الثقافة، والتي تهدف إلى المشاركة في رفع المستوى الثقافي وتوجيه الوعي القومي للجماهير في العديد من المجالات الثقافية مثل المسرح والموسيقى والفنون التشكيلية وخدمات المكتبات 
المستوى الثاني: العمال أنصاف المهرة ذوي المستوى المى المان التعليمي (ابتدائي/ إعدادي) ويحصل على درجتين مثل: النقاش - الطباخ - الفراش أو الساعي - عامل تصليح التليفونات.

المستوى الثالث: العمال اليدويون المهرة ذوي المستوى التعلمي (الثانوي أو ما يعادله) ويحصل على ثلاث درجات مثل: الممرض - الحلاق - السمكري - محصل بالنقل العام. المستوى الرابع: الكتابيون والمساعدون الفنيون وأصحاب المحلات الصغيرة والحرف الفنية ذوي المستوى التعليمي (الجامعي) ويحصل على أربع درجات مثل فني المعمل -

$$
\text { المقاول - الصراف - متعهد توريد الأغذية. }
$$

المستوى الخامس: القائمون بالأعمال الإدارية والمهنية وأصحاب الأعمال المستقلة ذوي المستوى التعليمي (الجامعي/ فوق الجامعي) ويحصل على خمس درجات مثل المهندس - الصيدلي - الطبيب - مدرس الإعدادي - ضابط

$$
\text { حتى رائد - محام - مأمور ضرائب. }
$$
ثانياً: منهج البحث:

يتبع البحث الحالي المنهج الوصفي التحليلي الذي يعتمد على دراسة الظاهرة كما توجد في الواقع ويهتم بوصفها وصفاً دقيقاً، ويعبر عنها تعبيراً كيفياً أو كمياً، فالتعبير الكيفي يصف لنا الظاهرة ويوضتح خصائصها، أما التعبير الكمي فيعطى وصفاً رقمياً يوضح مقدار هذه الظاهرة أو حجمها ودرجة ارتباطها مع الظواهر الأخرى (ذوقان عبيدات

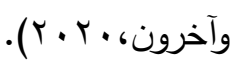

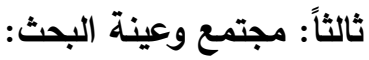

تطلب إجراء البحث وتحقيق أهدافه الرجوع الى عدة

$$
\text { مصادر وهي كالتالي: - مصاء }
$$

1- قصور الثقافة بالإسكندرية: تضمن مجتمع البحث قصور الثقافة بالإسكندرية وتم اختيار قصري ثقافة الأنفوشي والثاطبي بطريقة عمدية لما يتم فيها من تقديم
ويعرف الموهوبون إجرائياً بأنهم فئة المراهقين المترددين على قصور الثقافة بمحافظة الإسكندرية والذين سيتم اختيارهم بناء على المعايير الموضوعة وفقاً لأهداف البحث، فيكون الموهوب هو الذي يتفق حكم المدرب عليه في مجال الموهبة

والتي تشمل (الفن التشكيلي - الفن الثعبي والرقص الموسيقى والعزف - التمثيل والمسرح - الغناء والكورال نادى التكنولوجيا - نادى الأدب). ع -مرحلة المراهقة:

هي مرحلة النمو التي تبدأ في سن البلوغ أي من سن rا سنة تقريبا وتتتهي في سن النضج أي حوالي الثامنة عشرة أو العشرين من العدر • وهي سن النضج العقلي والانفعالي والاجتماعي وتصل إليها الفتاة قبل الفتى بنحو عامين وهي أوسع وأكثر شمولا من البلوغ الجنسي لأنها تتناول كل جوانب شخصية المراهق (عبد الرحمن العيسوي، $\cdot(r \cdot . \varepsilon$ وهي المرحلة النمائية الثالثة التي يمر بها الإنسان في حياته من الطفولة الى الرشد وتتميز بالنمو السريع في جميع الاتجاهات البدني والنفسي والعقلي والاجتماعي (محمد

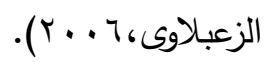

وسوف يتبنى البحث هذا التعريف كتعريف إجرائي للمراهقين في المرحلة العمريـة من | |-1 | سنة. ه- المستوى الوظيفي للأب والأم:

يقصد به في هذا البحث مستوى المهنة أو الوظيفة التي يشغلها الأب أو الأم مربوطاً بالمستوى التعليمي لهما، وذلك هدئك

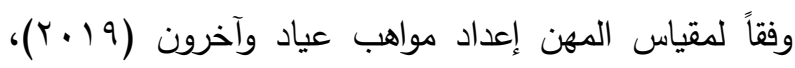
حيث تقسم المهن إلى خمسة مستويات كالتالي: المستوى الأول: العمال غير المهرة ذوي المستوى التعليمي المنخفض (أمي/ يقرأ ويكتب) ويحصل على درجة واحدة

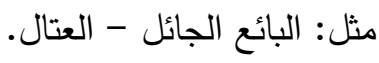




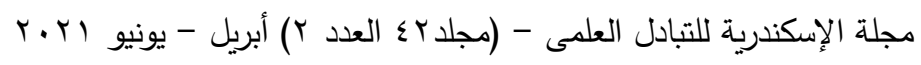

• مقياس السمات الثخصية المميزة للمراهقين الموهوبين موضنع الدراسة. وصف أدوات البحث: 1- الاستمارة الخاصة بالبيانات الاتية (الثخصية) والأسربة للمبحوثين من المراهقين الموهوبين رواد قصور لاليدات الثقافة: المحور الأول الخصائص الأتية (الثخصية) للمبحوثين المتردين على قصور الثقافة المدروسة: ويشتمل على أسئلة يجيب عنها المبحوث (النوع-العمر -

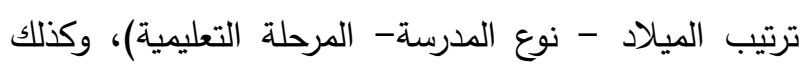
بيانات عن النشاط الرئيسي الممارس والفرعي والعمر عند بدء مزاولة النشاط ومدة مزاولته بقصر الثقافة. المحور الثاني: خصائص الأسرة ومساهماتها في تنمية قدرات ومهارات المبحوثين:

1- الخصائص الأسرية للمبحوثين المترددين على قصور الثقافة:

يتضمن هذا الجزء أسئلة يجيب عنها المبحوث حول (وجود الأب والأم والمرحلة العمرية لهما والمستوى التعليمي والوظيفي للأب والأم، وإجمالي الاخل الشهري للأسرة، وعدد الإخوة والأخوات، وعدد أفرد الأسرة المقيمين بالمسكن وعدد حجرات المسكن ودرجة التزاحم الحجري). r - مساهمات الأسرة في تنمية القدرات والمهارات المرتبطة بالموهبة لاى المبحوثين: أ- الممارسات الأسرية ذات العلاقة بالموهبة: يتضمن هذا المحور (ب^) عبارة يجيب عنها المبحوث" بنعم" أو "لا" وهي توضح ممارسات وسلوكيات قامت أو تقوم بها الأسرة مع الابن/ الابنة وهي سلوكيات وممارسات ذات علاقة إيجابية أو سلبية من حيث تأثيرها على موهبة أو الانه قدرات ومهارات الأبناء (تشجعها/تثبطها)، ويعطى درجتان في حالة الإجابة "بنعم " ودرجة واحدة في حالة الإجابة ب "لا "
أنشطة متعددة تجذب الرواد لمزاولتها. وتم الحصول على خطاب الموافقة من الإدارة المركزية لمكتب رئيس الهيئة العامة لقصور الثقافة للحصول على التقارير الثهرية التي تقدمها قصور الثقافة. r-الرواد المزاولون لجميع الأنشطة: تضمنت الثاملة جميع المترددين على جميع الأنشطة بقصري الثقافة عينة

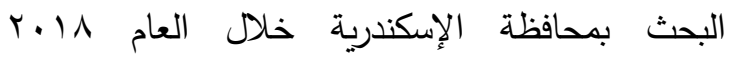

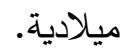
r-المدربون ومشرفو الأنشطة: ويتمثلوا في القائمين على التدريب في التخصصات المختلفة والذين من خلالهم يتم

$$
\text { التعرف على المواهب المختلفة. }
$$

ولسحب العينات من هذه المصادر تم اتباع أسلوب العينة متعددة المراحل Multistage Sample على النحو التالي: المرحلة الأولى: تم فيها اختيار قصور الثقافة بطريقة عمدية بمحافظة الإسكندرية والتي يتواجد بها العديد من الأنشطة الثقافية وعددهم (Y) هما قصري ثقافة الأنفوشي والثاطبي. المرحلة الثانية: وتم فيها اختيار عينة صدفية من الرواد المترددين على قصري ثقافة الأنفوشي والثاطبي بمحافظة الإسكندرية واللذين تصادف وجودهم وقت جمع البيانات ومنها تم اختيار العينات من المزاولين لنشاط الفنون التشكيلية، والموسيقى والعزف، والغناء والكورال، والتمثيل والمسرح، والفن الثعبي والرقص، ونادى التكنولوجيا، ونادى

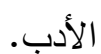
رابعاً: أدوات البحث: لتحقيق أهداف البحث تم الاستعانة بعدد من الأدوات والمقاييس كما يلى: • استمارة خاصة بالبيانات الذاتية (الشخصية) والأسرية للمبحوثين من رواد قصور الثقافة. • استمارة خاصة بالمدربين (مقياس الحكم على درجة الموهبة من وجهة نظر المدرب). 
يتضمن هذا الجزء ع عبارات تعكس اهتمام الأسرة

بتأهيل المبحوث علمياً وعملياً، ومعرفة كيف يتم ذلك (دعم هنرات الموهبة بالمعرفة والاطلاع، التحصيل العلمي، الدورات التدريبية، الإفادة من أصحاب الخبرات) ويعطى درجة واحدة عن كل أسلوب تتبعه الأسرة لتأهيل المبحوث، وبذلك تتراوح الدرجات ما بين (صفر - ع درجة).

يتضح مما سبق أن الدرجة الكلية التي تثير إلى مساهمات الأسرة في تتمية القدرات والمهارات المرتبطة بالموهبة لدى المبحوثين قد تراوحت ما بين 7 ـ - 9 درجة. كما تضمن هذا الجزء سؤالين عن الثخص الذي له الفضل في الارتقاء بموهبة المبحوث، وما هو تأثير مكان نشأته على الموهبة لديه.

المحور الثالث: الإحباطات الثخصية والأسرية التي يعاني

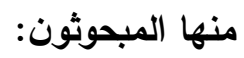
وتتضمن أسئلة لبيان ما إذا كان المبحوث يثعر بالإحباطات الشخصية أو الأسرية وما هي أسبابها 1- أسباب الشعور بالإحباطات الشخصية: وتتضمن (r ( ) عبارة يجيب عنها المبحوث" بنعم "أو" لا" وتشمل (الثعور بالملل من الأنشطة العادية - وجود عوائق تحول دون

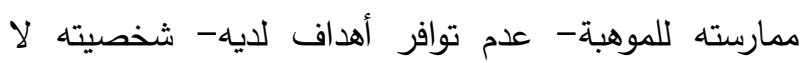
تجعله يتجاوز العوائق - عدم تحقيق رغباته، وعدم تكيفه مع الزملاء - عدم قبوله للأوامر - الرغبة في الوصول الى الكمال سخرية من حوله منه- الملل من كثرة الواجبات، وطول اليوم الدراسي - عدم تقدير موهبته) وتعطى درجة واحدة عند الإجابة "بنعم" ودرجتان عند الإجابة ب "لا" وبذلك تثير وليري الدرجة الأقل التي يحصل عليها المبحوث الى وجلى وجود إحباطات شخصية بدرجة مرتفعة، وتتراوح الدرجات ما بين Y I درجة كحد أدنى و ک برجة كحد أقصى. r-أسباب الشعور بالإحباطات الأسريةة: وتشتمل على (9) عبارات يجيب عنها المبحوث "بنعم" أو "لا" وتتمثل في (كثرة المشكلات في الأسرة وعدم استقرارها-عدم تفهم موهبته- عدم
في حالة العبارات الإيجابية والعكس في حالة العبارات السلبية، وتتراوح الدرجات بينمس-Vฯ درجة حيث تشير الدرجة الأعلى إلى ممارسات موجبة مشجعة للموهبة، بينما تشير الدرجة المنخفضة الى ممارسات سلبية قد تعوق إتى الموهبة وقد روعي عند صياغة العبارات أن تكون واضحة ومحددة وفي سياق الهدف.

ب - توافر القدوة والنموذج المشجع على الموهبة بدلالة الاتفاق في الهواية مع أفراد الأسرة: وتتمثل في التساؤلات التالية: - وجود فرد بالأسرة له نفس هواية المبحوث (وتعطى درجتان في حالة الاتفاق ودرجة واحدة عند الاختلاف). - مدى الاتفاق بين هواية المبحوث وكل من: الأب، والأم، والإخوة، ويعطى درجتان للإجابة "بنعم" عند الاتفاق بين

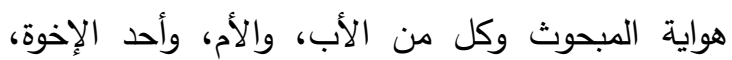
ودرجة واحدة في حالة عدم الاتقاق في الهوايات بين المبحوث وكل منهخ.

وبذلك تتراوح الدرجات في هذا الجزء ما بين ع-1 درجات. ج- تشجيع / تثبيط الأسرة للمبحوثين في مجال الموهبة: يتضمن هذا الجزء "§" عبارات تعكس عوامل التشجيع / التثبيط الأسرية من حيث (حرص الأسرة على الحاق المبحوث بمكان للتدريب فيه، وتوفير أدوات ووسائل لتنمية

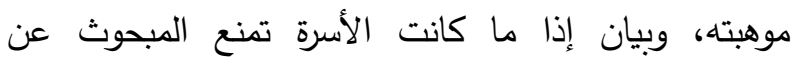
ممارسة هواياته، أو تسمح لله بممارستها في الإجازات فتط. يعطى درجتان عند الإجابة "بنعم" على العبارات الإيجابية ودرجة واحدة عند الإجابة ب "لا" والعكس في حالة العبارات السلبية، وبذلك تتراوح درجات هذا الجزء ما بين ع-1

$$
\text { درجات. }
$$

د- دور الأسرة في التأهيل العلمي والعملي في مجال

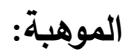




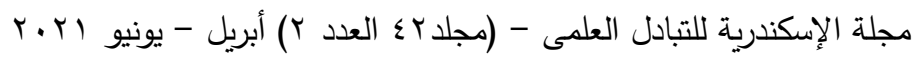

بالتفاصيل، والعلاقات، والقدرة على التفكير الناقد والحكم

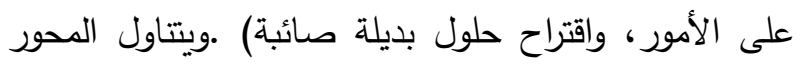
الثالث للمقياس الجوانب الاجتماعية لدى المتدرب (0عبارات ) من حيث (القدرة على التكيف بسرعة مع الأماكن والمواقف والآراء الجديدة، والمشاركة والتعاون مع الزملاء، والقدرة العالية على التأثير فيهه، وحسن الاستماع والتواصل مع ولهاء الآخرين، وحب عرض أعماله أمام الأخرين). أما المحور

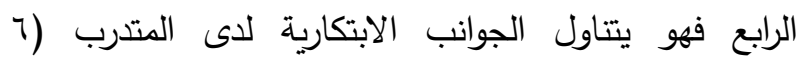
عبارات) من حيث (التمتع بإنتاج غزير في مجال موهبته، والابتعاد عن تكرار ما هو تقليدي، وإعطاء أفكار أصيلة وحلول جديدة غير مألوفة، والقدرة على مواصلة العمل في المهام الصعبة) ويجيب المدرب على المقياس بوضع علامة (صح) أمام السمة التي (تتطبق على المتدرب تماماً) أو (تطبق لحد ما) أو(لا تتطبق) ويتم تقدير الإجابات بدرجات r، 1، على التوالي وبذلك يكون المجموع الكلى لدرجات المتدرب على المقياس(· (9) درجة وتمثل الحد الأعلى حيث المهارة أو الموهبة الأعلى درجة، أما الحد الأدنى فهو (·) درجة. r- مقياس السمات الشخصية المميزة للمراهقين الموهوبين موضع الدراسة: يهدف هذا المقياس الى دراسة أهم السمات الشخصية التي يتصف بها الموهوبين من المبحوثين، وقد تم بناء المقياس بعد تحديد الهدف منه وتحديد المحاور والبنود التي تقيس سمات الثخصية، ثم تم وضع العبارات المناسبة ويتكون المقياس من (§ه) عبارة تعبر عن السمات الثخصية موزعة على المحاور التالية (تقدير الذات-الميول الاجتماعية- تحمل المسئولية- عقلانية السلوك- الاستقلالية -السلوك التوكيدي - القيادة- العدوانية- العصابية) وذلك الك بناءً على ما تم الاطلاع عليه من دراسات وبحوث ومقاييس مرتبطة بسمات الثخصية وهي:
توفير الأسرة للإمكانيات والبيئة المشجعة - عدم التواصل الأسرى والمدرسي - انخفاض المستوى التعليمي والثقافي والاقتصادي للأسرة- الأساليب الأسرية المتثددة) وتعطى ولى ولى درجة واحدة عند الإجابة "بنعم" ودرجتان عند الإجابة بـلا" وبذلك تثير الدرجة الأقل الى وجود إحباطات أسرية بدرجة

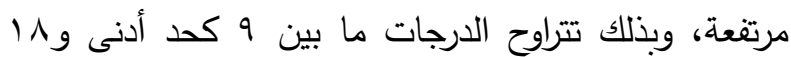
درجة كحد أقصى.

r - الاستمارة الخاصة بالمدربين (مقياس تقييم درجة الموهبة للمبحوثين من خلال الخصائص السلوكية لايهم من وجهة نظر المدرب): تم الاطلاع على الدراسات والبحوث السابقة التي تتاولت الموهبة والموهوبين كما تم الاطلاع على المقاييس التالية: ا. مقياس الخصائص السلوكية للموهوبين عبد الرحمن

$$
\text { سليمان، السيد حسن (0. ( . ب). }
$$

r. مقياس (رينزولي) لتقدير الخصائص السلوكية للمتفوقين

$$
\text { تعريب كاظم زيد، وصباح حمزة (10 • r). }
$$

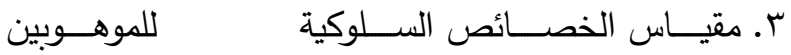
Sternberg (2005).

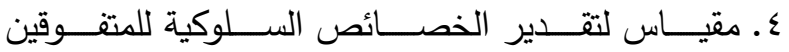
. Renzulli et al (2009) ه. مقياس الخصائص المميزة للموهوبين سامر عياصرة

$$
\text { ونور عزيزي (r ( • (r). }
$$

وبعد الاطلاع على المقاييس السابقة تم إعداد هذا المقياس الذي يهدف إلى تقييم الخصائص السلوكية المميزة للموهوبين والتي من خلالها يتم الحكم على موهبتهم من وجهة نظر المدربين، يتضمن المقياس (·r) عبارة يبدأ ب(• (1 عبارات) يقيم المدرب من خلالها المستوى المهارى للمتدرب في موهبته أو القدرة الخاصة التي يبرع فيها بين زملائه من حيث(الكفاءة والمهارة والإتقان والتميز والسهولة والدقة في الأداء) وهو المحور الأول للمقياس، يليه المحور الثاني (وعبارات) ويتاول أسلوب المتدرب في التقكير من حيث (اعتماده على نفسه، وقدرته على التخيل، والاهتمام 
ولقد تم تقنين المقياسين (معيار الحكم على درجة الموهبة، ومقياس السمات الثخصية المميزة للمبحوثين الموهوبين) عن طريق اختبار الصدق والثبات، وذلك بإجراء

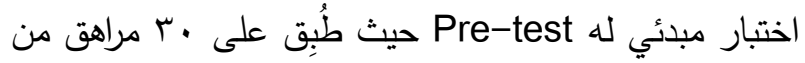
اللذين تصادف وجودهم بقصري ثقافة الأنفوشي والثاطبي، وحولت البيانات الوصفية إلى كمية في كل محور لإجراء المعاملات الإحصائية، ولقد تم التحقق من صدق المقاييس بطريقتين: أ - صدق المحتوى: حيث تم عرض تلك المقاييس على عدد (V) من المحكمين للحكم على الصدق الظاهري ضمت المتخصصين في مجال الأمومة والطفولة والرعاية الأسرية والإرشاد الاقتصادي المنزلي والعلوم التربوية، وقد كان لهؤلاء المحكمين بعض المقترحات الخاصة بصياغة بعض العبارات، وإعادة تنظيم بعض البنود، والتي تم وضعها في الاعتبار في التصميم النهائي للمقاييس حيث تم تعديل بعض العبارات في ضوء الملاحظات التي عرضها المتخصصون، كما تم حذف العبارات التي تقل نسبة الاتفاق حولها عن $\%$.

ب- صدق الاتساق الداخلي وذلك عن طريق إيجاد معامل الارتباط لبيرسون بين الدرجة الكلية لكل محور وبين الدرجة الكلية للمقياس كما يوضحها جدول (1) حيث تبين أن قيم معاملات الارتباط دالة عند مستوى معنوي (1 (.,.) مما يدل جلئل على صدق الاتساق الداخلي للمقاييس.
1. مقياس (ريموند كاتل) للشخصية ترجمة محمد عبد الرحمن وصالح أبو عبادة (991 (1) ). r. مقياس سمات الثخصية محمد أبو عليا (1911) ). r. مقياس (كوستا وماكري) لسمات الثخصية ترجمة أحمد عبد الخالق، ومحمد الأنصاري (1997 ()).

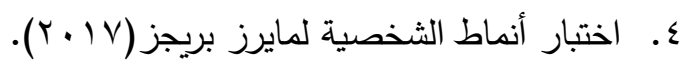
๑. مقياس Eysenck \& Eysenck (1975) للشخصية

$$
\text { ترجمة محمد الأنصاري (..... (†). }
$$

7. مقياس سمات الشخصية وفقا لنظرية Erikson ترجمة

$$
\text { فاروق عثمان (0. . ب). }
$$

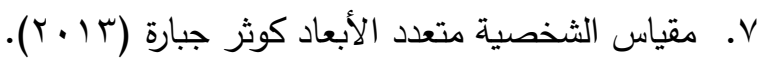
وبعد أن تم وضع عبارات تغطي المحاور السابقة وضعت تعليمات الإجابة على المقياس التي تتص على وضع المبحوث علامة (صح) أسفل عمود "نعم" في حالة انطباق الصفة معه وأسفل العمود "لا" إذ لم تتطبق الصفة معه وذلك على مقياس ثنائي، حيث يعطى المبحوث (درجتان عند الإجابة بنعم، ودرجة واحدة عند الإجابة بلا) في حالة العبارات الإيجابية، أما في حالة العبارات السلبية يعطى (درجة واحدة عند الإجابة بنعم، ودرجتان عند الإجابة بلا) وتحسب الدرجة الدالة على سمات الثخصية بمجموع الدرجات التي يحصل عليها المبحوث ويتراوح المدى النظري بين (1 • (1) درجة كدد أعلى،(ع) درجة كحد أدنى وتعبر الدرجة الأعلى عن شخصية ذات سمات إيجابية بدرجة

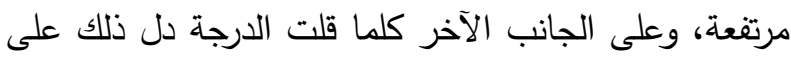
اتصاف المبحوث بخصائص أو سمات سلبية وغير مرغوبة. 


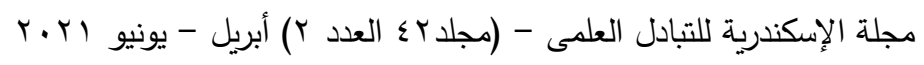

جدول ا. قيم معاملات الارتباط لمحاور مقياسي الحكم على درجة الموهبة من وجهة نظر المدرب وسمات الثخصية المميزة للمبحوثين الموهوبين

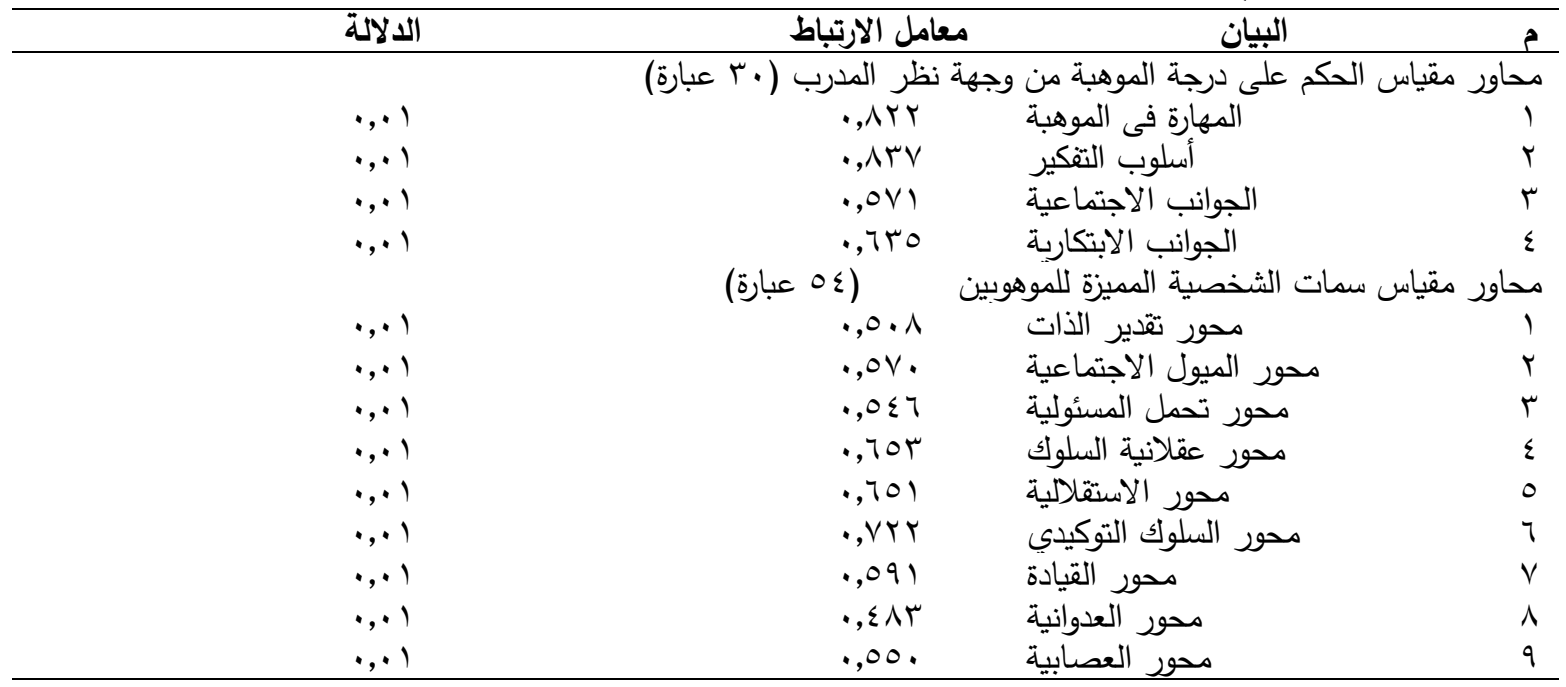

r-حساب التكرارات والنسب المئوية والمتوسطات والانحراف المعياري لوصف العينة وتحديد خصائصها الذاتية

$$
\text { (الشخصية) والأسرية. }
$$

ع - اختبار الانحدار المتعدد Multiple Regression لبيان العلاقة التأثيرية بين المتغيرات المستقلة والمتغيرات التابعة.

\section{النتائج البحثية}

أولاً الخصائص الأتية (الشخصية) للمبحوثين المترددين على قصور الثقافة المدروسة:

1-النوع وفئات العمر وترتيب الميلاد ونوع المدرسة والمرحلة التعليمية للمبحوثين:

يشير جدول (Y) الى توزيع المبحوثين المترددين على "مأى قصري ثقافة الأنفوشي والثاطبي وفقاً للنوع وفئات العمر لتربي

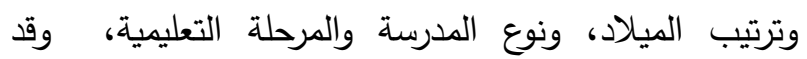

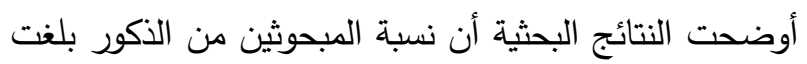

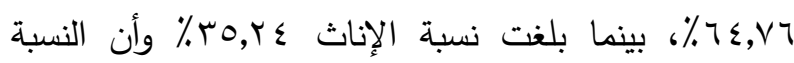
الأكثر ارتفاعاً كانت للفئة العمرية من (ع ا لأقل من V اسنة)

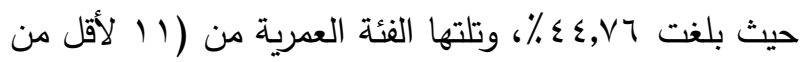

ج-ثبات المقاييس: تم التحقق من ثبات المقياسين باستخدام معامل ألفا كرونباخ Alpha Cronbach وقد اتضح أن لن لهن قيمة معامل الثبات قد بلغت (؟rو. •) لمقياس الحكم

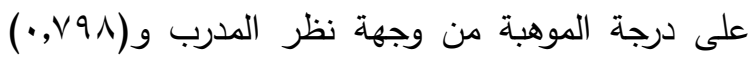
لمقياس السمات الثخصية المميزة للموهوبين المبحوثين وهي قيم مرتفعة مما يدل على ثبات المقياس، وصلاحيته

$$
\text { لماستخدام في الدراسة. }
$$

خامساً: المعاملات الإحصائية المستخدمة في البحث: تم تحليل البيانات وإجراء المعالجات الإحصائية باستخدام برنامج الحزم الإحصائية للعلوم الاجتماعية Statistical Package of Science (SPSS)V.26 الإصدار رقم (YT) بعد إخخال البيانات ومراجعتها لضمان صحة النتائج ودقتها، وقد تم استخدام بعض الأساليب الإحصائية للكثف عن العلاقة بين متغيرات البحث ومن هذه الأساليب: ا-صدق الاتساق الداخلي باستخدام معامل ارتباط بيرسون لحساب صدق المقياسين المستخدمين في البحث. r- معامل ألفا كرونباخ لتحديد درجة ثبات المقياسين المستخدمين. 


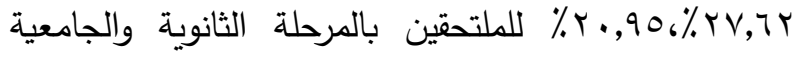

$$
\text { على التوالي. }
$$

r- النشاط الرئيسي والأنشطة الفرعية التي يمارسها المبحوثون في القصور المدروسة: يثير جدول (ب) الى توزيع المبحوثين المترددين على قصري ثقافة الأنفوشي والثاطبي وفقا للأنشطة الرئيسية والفرعية التي يمارسونها، والعمر عند مزاولة النشاط ومدة

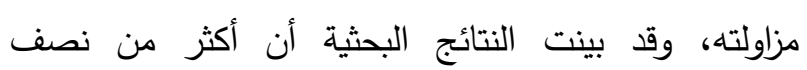

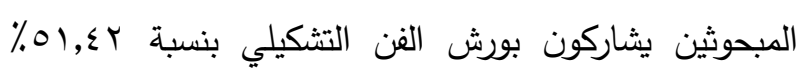
كنشاط رئيسي، وجاءت فرق الفن الثعبي والرقصات بنسبة

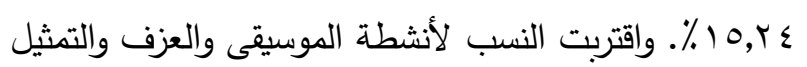

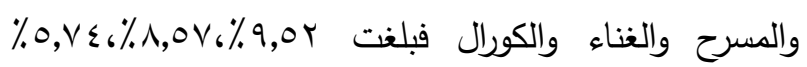
على التوالي، بينما تساوت نسبة الممارسين لأنشطة نادى ولغ واء

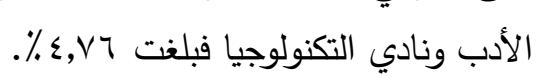

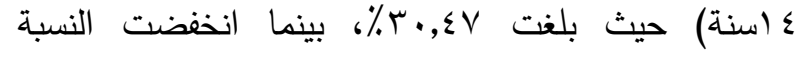

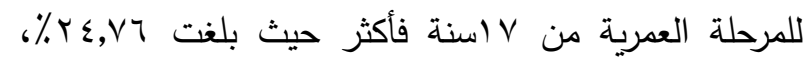
وقد بلغ المتوسط والانحراف المعياري ع 10,V + +. Y, سنة. كما أوضحت النتائج البحثية أن نسبة المبحوثين في ترتيب الميلاد الأول كانت مرتقعة فبلغت ^r,به٪، وجاءت

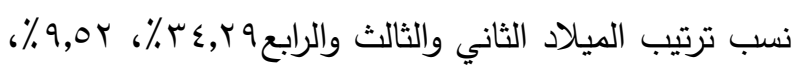

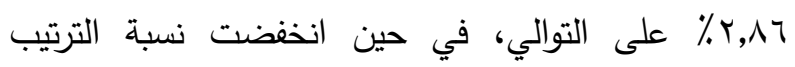
الخامس فبلغت 90, ٪ ٪. ويشير نفس الجدول إلى توزيع المبحوثين المترددين على قصري الأنفوشي والثاطبي وفقاً لنوع المدرسة والمرحلة التعليمية حيث أوضحت النتائج البحثية ارتفاع نسبة المبحوثين الملتحقين بالمدارس الحكومية حيث بلغت 90, ، ٪\%، في حين بلغت نسبة الملتحقين بالمدارس الخاصة 0 ×.9 ٪، وكانت أعلى نسبة للملتحقين

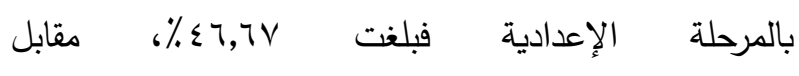

جدول r ـ توزيع المبحوثين وفقاً للخصائص الأتية (الشخصية)

\begin{tabular}{|c|c|c|}
\hline$\%$ & العدد (ن=0.0 1. & خصائص المبحوثين \\
\hline & & 1-النوع \\
\hline $7 \varepsilon, \vee T$ & $\uparrow \wedge$ & ذكر \\
\hline$r 0, Y \leq$ & rV & أنثى \\
\hline & & r - بئات العمر \\
\hline$r \cdot, \Sigma V$ & rt & -11 \\
\hline$\varepsilon \varepsilon, \vee \uparrow$ & $\varepsilon \vee$ & $-1 \leqslant$ \\
\hline \multirow[t]{3}{*}{$r \varepsilon, V T$} & r & $-1 V$ \\
\hline & $Y, 0 \cdot+10, V \leqslant$ & المتوسط الحسابي والانحراف المعياري \\
\hline & & س- ترتيب الميلاد \\
\hline or,rᄉ & 00 & الأول "“. \\
\hline$r \varepsilon, Y q$ & צ & 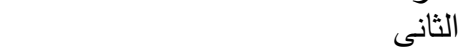 \\
\hline $9,0 Y$ & 1. & الثالث \\
\hline r,Ат & r & 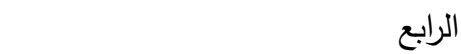 \\
\hline., 90 & 1 & 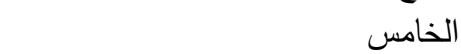 \\
\hline 19.00 & $r$. & خاص \\
\hline $1 . .90$ & 10 & 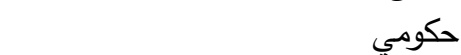 \\
\hline $1 \ldots$ & 1.0 & المجموع \\
\hline$\varepsilon . V 7$ & 0 & ابتدائي \\
\hline$\varepsilon 7.7 V$ & $\leqslant 9$ & إعدادي" \\
\hline rV.Tr & rq & 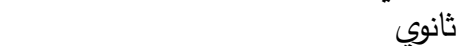 \\
\hline$r \cdot .90$ & rt & جامعي \\
\hline
\end{tabular}




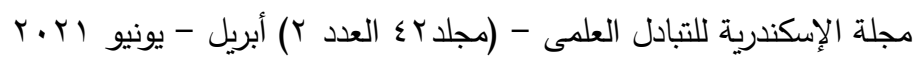

جدول r. توزيع المبحوثين وفقا للنشاط الرئيسي الممارس والفرعي والعمر عند بدء مزاولة النشاط ومدة مزاولته بقصر الثقافة

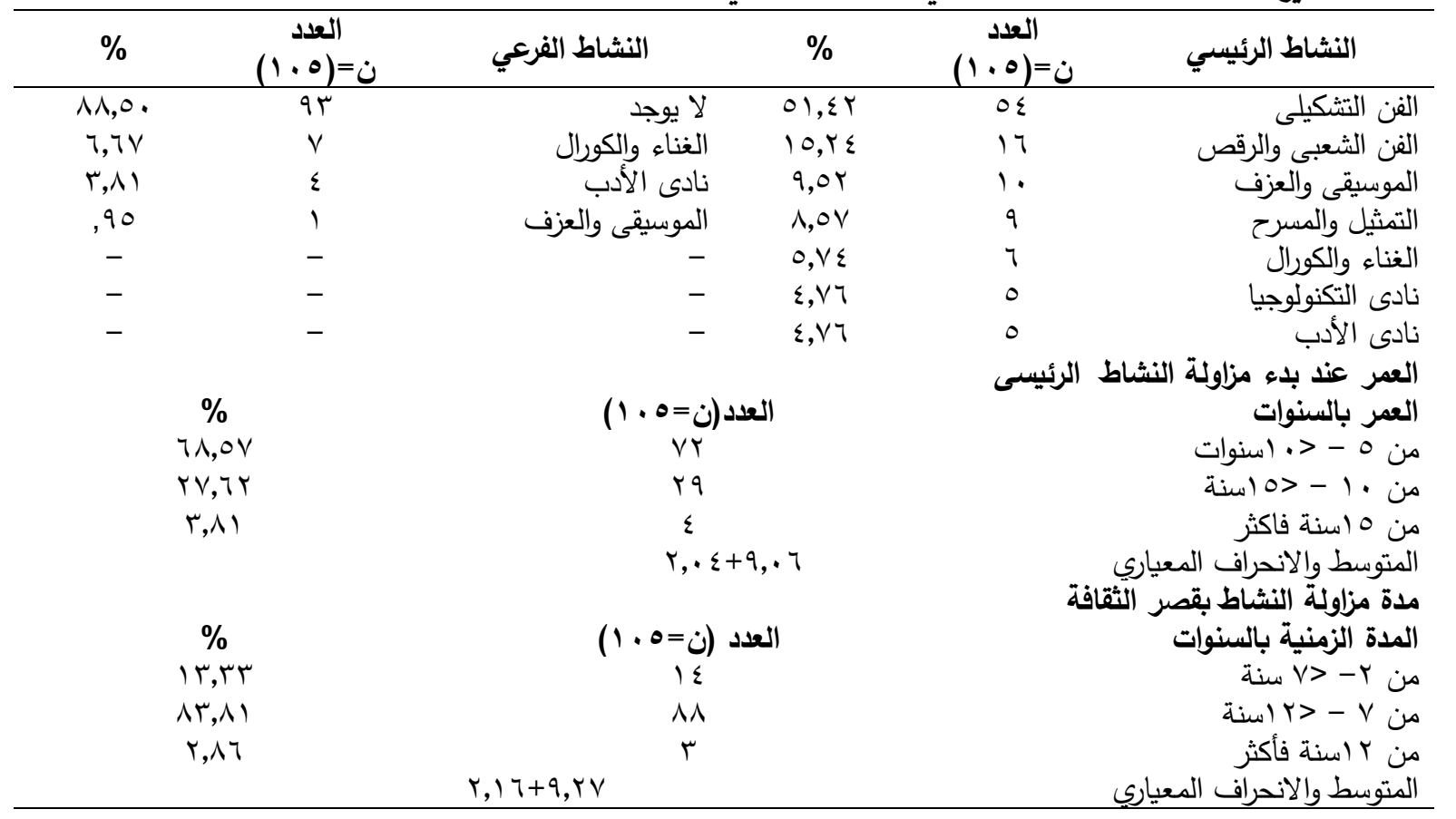

ثانياً خصائص الأسرة ومساهماتها في تنمية قرات ومهارات المبحوثين:

1- الخصائص الأسرية للمبحوثين المترددين على قصور الثقافة: يشير جدول (ع) إلى توزيع المبحوثين وفقاً لبعض خصائصهم الأسرية: - ( -وجود الأب والأم والمرحلة العمرية لهما: أوضحت النتائج البحثية تمتع المبحوثين بوجود الأب

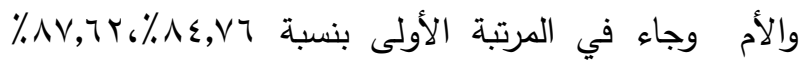
على الترتيب، وأن عدم وجود الأب أو الأم لدواعي السفر جاء

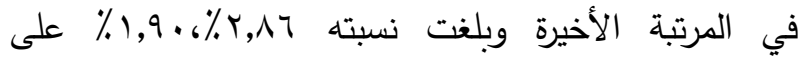
الترتيب، وبينت النتائج ارتفاع نسبة أباء المبحوثين في

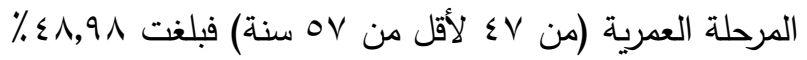
بينما جاءت أعلى نسبة للأمهات 9 9,9ء ٪ ممن بالمرحلة العمرية (من •ب لأقل من ·عسنة)، في حين اقتربت النسبة في المرحلة العمرية V O سنة فأكثر للآباء، و •.
كما أوضحت النتائج البحثية أن الغالبية العظمى من المبحوثين يمارسون نشاط رئيسي واحد ولا يمارسون أنشطة

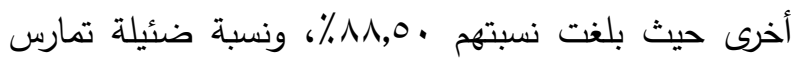
نشاط إضافي كالغناء أو نادى الأدب أو الموسيقى وبلغت

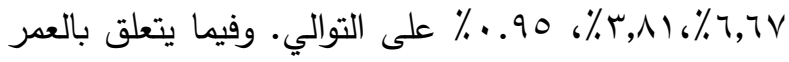
عند بدء مزاولة النشاط أظهرت النتائج أن أكثر من ثلثي

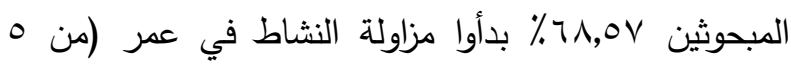

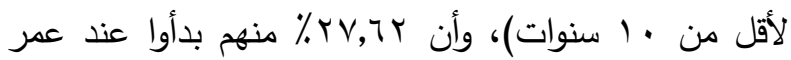
(من • ا لأقل من 10 سنة)، وتراوح متوسط العدر عند بدء

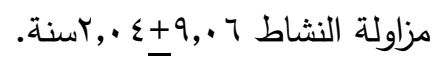
كذلك أظهرت النتائج أن مدة مزاولة النشاط لـ וر,rیر٪

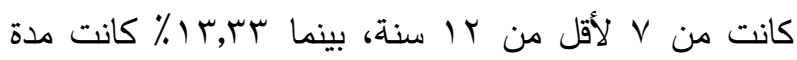
مزاولة النشاط لايهم من سنتين لأقل من V سنوات، وقد بلغ متوسط مدة مزاولة المبحوثين للنشاط بقصور الثقافة

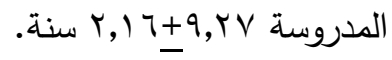




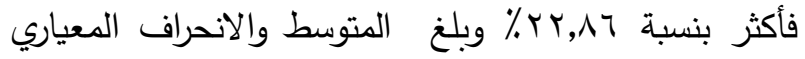
1. فرد. $1.0+\varepsilon$

- عدد حجرات المسكن ودرجة التزاحم الحجري: كما أوضحت النتائج البحثية أن أكثر من نصف أسر

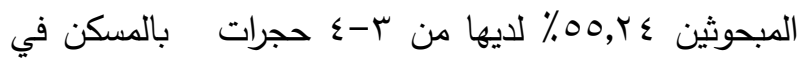

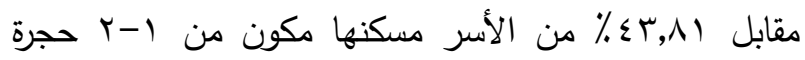

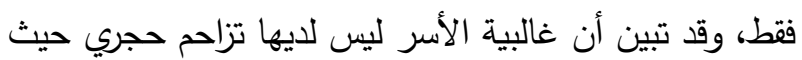

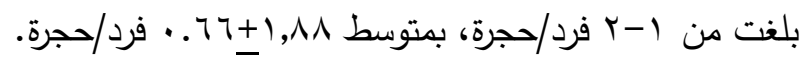
r - مساهمات الأسرة في تنمية القدرات والمهارات المرتبطة بالموهبة لاى المبحوثين: يتتاول هذا الجزء من البحث تقديم صورة شاملة عن الدور الذي تلعبه الأسرة في تشجيع أو تثبيط الموهبة لدى أبنائها وذلك من خلال التعرف على الممارسات التي تتبعها الأسرة ذات العلاقة بالموهبة، ومدى توافر القدوة بالأسرة، والتأهيل العلمي والعملي في مجال الموهبة. أ- الممارسات الأسرية ذات العلاقة بالموهبة: يبين جدول (0) توزيع المبحوثين المترددين على قصري ثقافة الأنفوشي والثاطبي وفقاً لإجاباتهم على العبارات التي تعكس الممارسات الأسرية ذات العلاقة بالموهبة حيث بينت النتائج البحثية أن جميع الأسر حرصت على توفير الوسائل السمعية والبصرية والإلكترونية لأبنائها مما يدعمه ويحفز على تتمية مهاراتهم فبتعدد تلك الوسائل وتتوعها لتزداد قدرتهم

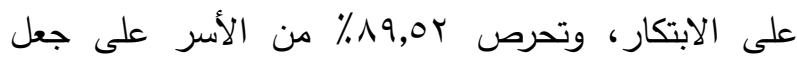
أبنائها متميزين، و ، ^٪ من الأسر تحرص على توفير المكان المناسب بالمنزل لمزاولة الأنشطة.

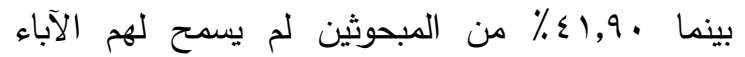
باللعب لمدة طويلة حرصاً منهم على الاستفادة بأوقاتهم وتعزيز مهاراتهم بما هو مفيد، وبينت النتائج البحثية أن

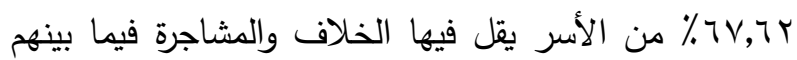
مما يحقق الهدوء والاستقرار والقبول ودعم الأبناء وتحفيزهم لممارسة مهارتهم بالمنزل واكتشاف مواهبهم.

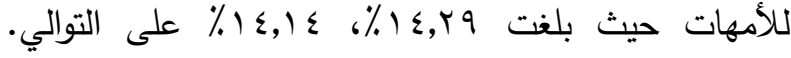
وجاء المتوسط والانحراف المعياري لأعمار الآباء والأمهات

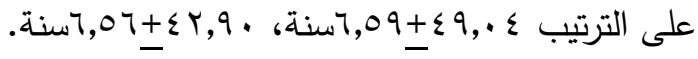
-المستوى التعليمي للأب والأم: تثير النتائج إلى تقارب نسبة الآباء والأمهات من ذوى

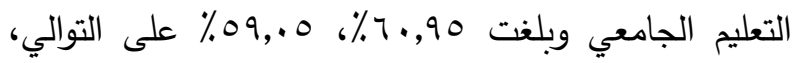
وكذلك نسبة ذوى التعليم المتوسط أو الثانوي فبلغت

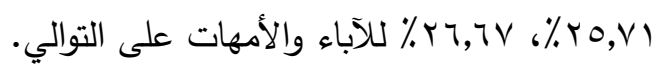
-المستوى الوظيفي للأب والأم: بينت النتائج البحثية أن نسبة آباء المبحوثين ممن

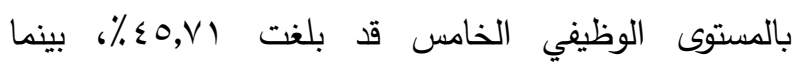
انخفضت لمن هم في المستوى الثاني بنسبة ایرب٪، بينما جاءت الأمهات اللاتي لا تعملن بالمرتبة الأولى فبلغت ^r,ro \% وتلتها من هن بالمستوى الوظيفي الخامس وبلغت

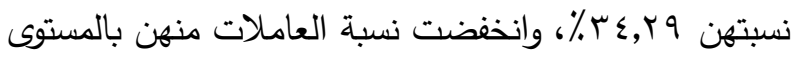
الثالث حيث بلغت 90, • ٪. - إجمالي الاخل الثهري للأسرة: أظهرت النتائج أيضاً أن إجمالي الدخل الثهري لأسر

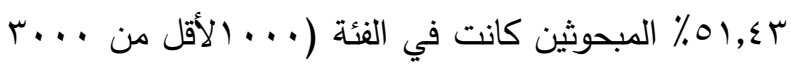
جنيه) وهو الأكثر ارتفاعاً، بينما انخفضت النسبة فبلغت

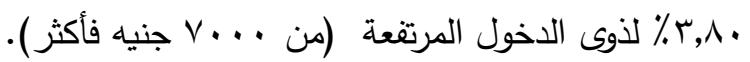
- عدد الإخوة والأخوات: توضح النتائج البحثية أن • 9, 1 ٪\% من المبحوثين لايهم

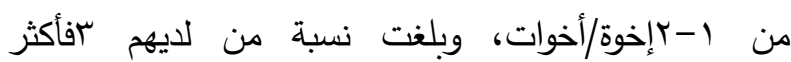

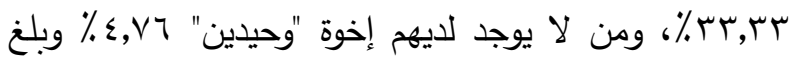

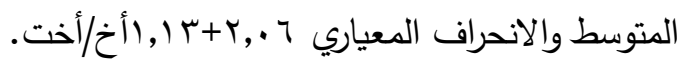
- عدد أفراد الأسرة المقيمين بالمسكن أوضحت النتائج البحثية أن النسبة الأعلى والتي بلغت 10.V1\% جاءت للأسر التي يتراوح عدد أفرادها المقيمين بالمسكن من ع-ه فرد تلتها الأسر التي عدد أفرادها ج أفراد 
جدول ء. توزيع المبحوثين وفقاً لخصائصهم الأسرية

\begin{tabular}{|c|c|c|c|c|c|}
\hline \multicolumn{3}{|c|}{ الأم } & \multicolumn{2}{|c|}{ الأب } & \multirow{2}{*}{ البيان } \\
\hline \multicolumn{2}{|r|}{$\%$} & العدد(ن=0 o 1 1) & $\%$ & العدد(ن=0 . 1 ( ) & \\
\hline & & & & & - وجود الأب والأم: \\
\hline & $N V, T Y$ & 94 & $\Lambda \varepsilon, V \uparrow$ & $\wedge 9$ & موجود/موجودة \\
\hline & $0, V_{1}$ & 1 & $7,7 \mathrm{~V}$ & $\mathrm{v}$ & وفاه \\
\hline & $\varepsilon, \vee \uparrow$ & o & $0, v_{1}$ & 1 & انفصال \\
\hline & 1,9 & r & r,Aт & r & - عمر الأب والأم: \\
\hline$\%$ & العدد (ن=9 9 9) & عمر الأم & $\%$ & 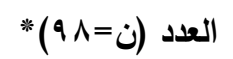 & عمر الأب \\
\hline$\varepsilon 9, \leqslant 9$ & $\leqslant 9$ & . & r & ז & 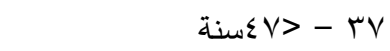 \\
\hline דז, ד & ד & . . - > 0. سنة . & $\{\lambda, १ \wedge$ & $\leqslant \Lambda$ & 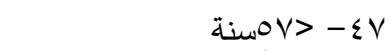 \\
\hline $1 \leqslant, 1 \leqslant$ & $1 \varepsilon$ & . مسنة فأكثر & $1 \varepsilon, r q$ & $1 \varepsilon$ & 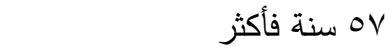 \\
\hline \multicolumn{3}{|c|}{ 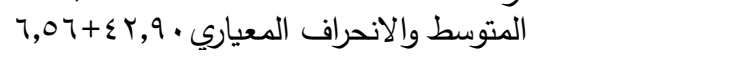 } & \multicolumn{2}{|c|}{$7,09+\varepsilon 9, \cdot \varepsilon$} & المتوسط والانحراف المعياري \\
\hline $\begin{array}{c}\% \\
0 . v 1\end{array}$ & العدد (ن= ه . 1 ) & تقرأ وتكتب التعليمى للأم & $\begin{array}{l}\% \\
T r . V\end{array}$ & العدد (ن=0 ه 1 ) & يقرأ ويكتب المتوى التعليمى للأب \\
\hline $0 . v 1$ & 7 & إقدل من متوسط أو & $\varepsilon . \vee 4$ & 。 & أقل من متوسط أو إعدادي \\
\hline Yฯ.TV & ru & تُعليم متوسط أو ثانوي & ro.ri & rv & تعليم متوسط أو ثانوي \\
\hline $09, .0$ & Tr & تعليم جامعى & $7 . .90$ & $T \varepsilon$ & تعليم \\
\hline. .90 & 1 & دراسات عليا" دبلوم" &. .90 & 1 & دراسات عليا "دبلوم" \\
\hline 1,9 . & r & ماجستير & - & - & 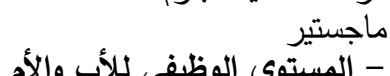 \\
\hline$\%$ & العدد (ن=0 ـ ـ 1) & المستوى الوظيفى للأم & $\%$ & العدد (ن=ه . 1) & المستوى الوظيفى للأبَ \\
\hline - & - & & $r, \wedge)$ & $\varepsilon$ & الكستوى الثنانى " \\
\hline ,90 & 1 & المستوى الثالث & $9,0 Y$ & 1. & المستوى الثالث \\
\hline $\mid r, \Gamma \Lambda$ & $\pi$ & المستوى الرابع & $r, \varepsilon r$ & r & المستوى الرابع \\
\hline$r \leqslant, r q$ & ry & المستوى الخامس & $\{0, v)$ & $\{1$ & المستوى الخامس \\
\hline Or, rA & 00 & لا لا تعل ل ل ل ل ل & $9,0 \mathrm{r}$ & 1. & معاش \\
\hline & $\%$ & & العدد (ن) & & 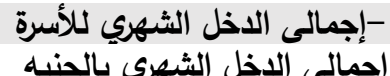 \\
\hline & $0, V_{1}$ & & 7 & & 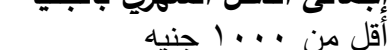 \\
\hline & $01, \varepsilon r$ & & o & & $r \ldots>-1 \ldots$ \\
\hline & $r r, \Lambda)$ & & ro & & $0 \ldots>-r \ldots$ \\
\hline & $10, r \varepsilon$ & & 17 & & $v \ldots>-0 \ldots$ \\
\hline & $r, \wedge$. & & $\varepsilon$ & & عدد الإخوة والأخوات \\
\hline & $\varepsilon, \vee \uparrow$ & & o & & 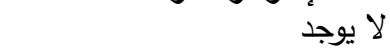 \\
\hline & $71,9$. & & 70 & & 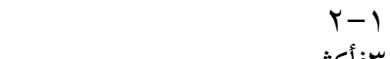 \\
\hline & זr, & $1,1 r+r, \cdot T$ & To & & 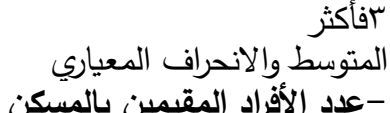 \\
\hline & $11, \varepsilon r$ & & Tr & & $r-r$ \\
\hline & $70, \sqrt{1}$ & & 79 & & $0-\varepsilon$ \\
\hline & rY,Aт & & $r \varepsilon$ & & 7 أفثرث \\
\hline
\end{tabular}




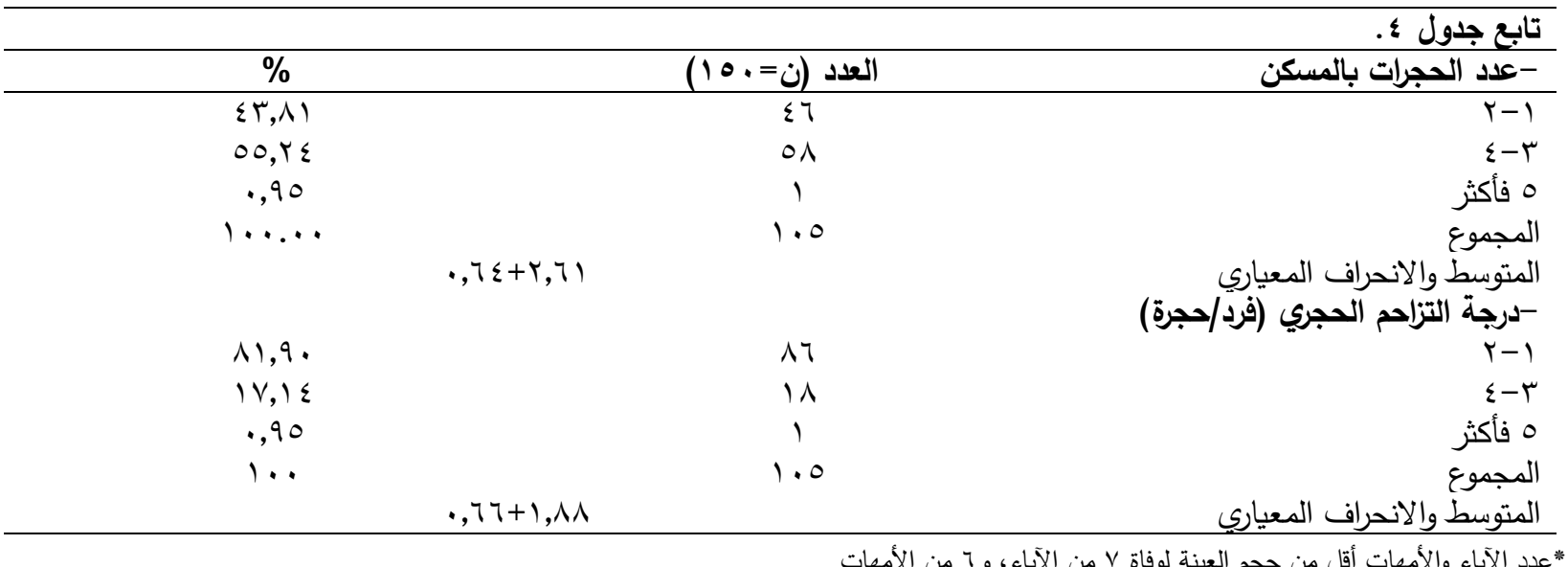

جدول ه. توزيع المبحوثين وفقاً للممارسات الأسرية ذات العلاقة بالموهبة

\begin{tabular}{|c|c|c|c|c|c|}
\hline \multicolumn{2}{|c|}{$y$} & \multicolumn{2}{|c|}{ نعم } & \multirow{2}{*}{ العبارات } & \multirow[b]{2}{*}{$r$} \\
\hline$\%$ & العدد & $\%$ & العدد & & \\
\hline- & - & $1 \ldots$ & 1.0 & ية والبصرية والإلكترونية لي & 1 \\
\hline $1 \cdot, \Sigma \Lambda$ & 11 & $\wedge 9,0 Y$ & $9 \leq$ & & Y \\
\hline $11, \varepsilon \pi$ & ir & $\Lambda \wedge, 0 \mathrm{~V}$ & $9 \pi$ & توفر & r \\
\hline $1 \wedge, 1$. & 19 & $11,9$. & 14 & & $\varepsilon$ \\
\hline$r \cdot, \ldots$ & r) & $\Lambda,, \cdots$ & $\Lambda \varepsilon$ & لتى بالمنزل & 0 \\
\hline$r \cdot, 90$ & $r r$ & $\vee q, .0$ & NT & تطلعاتى & 7 \\
\hline$r \cdot, 90$ & $r r$ & $\vee q, .0$ & NT & ل عاراتى & V \\
\hline$r \cdot, 90$ & $r r$ & $\vee q, .0$ & NT & تشج & $\Lambda$ \\
\hline Y 1,9. & r & $\vee \wedge, 1$. & Ar & إد على النفس & 9 \\
\hline YY,AT & $r \varepsilon$ & $V V, 1 \leq$ & 11 & اهتم & 1. \\
\hline$r r, \wedge)$ & ro & $v 7,19$ & $\wedge$. & تواجهنى & 11 \\
\hline$r r, \wedge)$ & ro & $v 7,19$ & $\wedge$. & تتقبل & IT \\
\hline$r 0, v)$ & $r V$ & $V \varepsilon, Y q$ & $\vee \wedge$ & تشج & س \\
\hline$Y 0, V)$ & $r V$ & $V \leqslant, r q$ & V^ & شا ال & $1 \varepsilon$ \\
\hline Y ,TV & $r \Lambda$ & سז, & $V V$ & تدعد & 10 \\
\hline Y T,TV & $r \Lambda$ & سT,T & $V V$ & لا ته & 17 \\
\hline$r 7, T V$ & rᄉ & سT, & $V V$ & ة فتظهر موهبتى & iv \\
\hline Y $7,7 V$ & rA & V & VV & & 11 \\
\hline Y & r^ & Tr, & VV & شر & 19 \\
\hline rV,Tr & $r q$ & $\checkmark Y, r \wedge$ & $V 7$ & المختلفة & $r$. \\
\hline$r V, T Y$ & $r q$ & VY,TA & VI & يتوق & YI \\
\hline 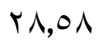 & $r$. & $v 1, \varepsilon r$ & vo & منذ الصغر & rr \\
\hline YA,OV & $r$. & $v_{1}, \leqslant r$ & vo & المادية والفنية لرعاية مواهبى & r \\
\hline YA,OV & r. & $v_{1}, \leqslant r$ & vo & توفر أس & $r \varepsilon$ \\
\hline rA,OV & r. & $\vee 1, \varepsilon r$ & vo & & ro \\
\hline Y^,OV & r. & $v_{1}, \varepsilon r$ & vo & قد. & r \\
\hline Y 9,0 r & r & $\vee \cdot, \Sigma \Lambda$ & $\vee \varepsilon$ & 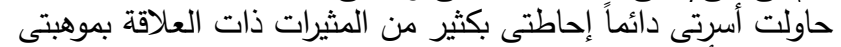 & rV \\
\hline Y १,० & r & $\vee \cdot, \leqslant \Lambda$ & $\vee \varepsilon$ & تعاونت & rᄉ \\
\hline rq,० & 衤 & $\vee \cdot, \varepsilon \wedge$ & $V \varepsilon$ & لدى أسرتى معلومات كافية عن مهارتى أو قدراتى الخاصة & rq \\
\hline אוזr & $r \varepsilon$ & $T V, T Y$ & v) & تقبل أسر & r. \\
\hline 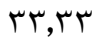 & ro & $77,7 \mathrm{~V}$ & $\vee \cdot$ & توفر أسرتى الكتب والمجلات وآلألعاب بالمنزل & M \\
\hline 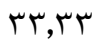 & ro & $77,7 \mathrm{~V}$ & $\vee \cdot$ & أسرتى كانت تأخذنى الى رحلات ومعارض مختلفة & rt \\
\hline ro,r & re & $7 \varepsilon, \vee\urcorner$ & 71 & يشجعنى أبى أمى على أن ابحث عن إجابة لأسئلتى بنفسى & r \\
\hline
\end{tabular}




$$
\text { مجلة الإسكندرية للتبادل العلمى - (مجلد بs العدد r) أبريل - يونيو ب.r }
$$

\begin{tabular}{|c|c|c|c|c|c|}
\hline \multicolumn{2}{|c|}{$\gamma$} & \multicolumn{2}{|c|}{ نعم } & \multirow{2}{*}{ العبارات } & \multirow[b]{2}{*}{ p } \\
\hline$\%$ & 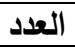 & $\%$ & 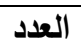 & & \\
\hline$r 7,19$ & $r \wedge$ & (ז,N & $7 V$ & ن الموهوبين ووصولهح الى القدم وتحبب شخصياتهم اليّ & $\Gamma \varepsilon$ \\
\hline$r v, l \leq$ & rq & TY,AT & 77 & د مكان واضح & ro \\
\hline rᄉ,l. & $\varepsilon$. & $71,9$. & 70 & تشجح & ד \\
\hline$\leqslant 1,9$. & $\varepsilon \varepsilon$ & $0 \wedge, 1$ & 7) & ج لى باللعب لمدة طويلة & rV \\
\hline ru,ru & $r \varepsilon$ & $T V, T Y$ & V) & الخلاف والمشاجرة والانفصال & rᄉ \\
\hline
\end{tabular}

يوفرونه من المناقثات والرحلات العمية وتتوع الثقافات المختلفة مما يحقق لهم ولأبنائهم المزيد من الأفكار المبتكرة في العديد من المجالات الثقافية والإبداعية والإنتاجية. كما لوحظ اتفاق المبحوثين مع أخوتهم وأخواتهم في الهوايات

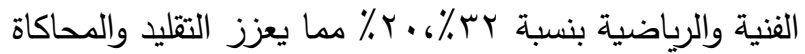
لاى الإخوة بعضهم وبعض حيث يقضون معظم الوقت معاً في ممارسة أعمال فنية أو الرياضات والرحلات والزيارات وغيرها من الأنشطة المختلفة.

ج - تشجيع / تثبيط الأسرة للمبحوثين في مجال الموهبة: يثير جدول (^) إلى توزيع المبحوثين وفقاً لتشجيع/ تتبيط الأسرة لهم حيث بينت النتائج البحثية أن الغالبية العظمى من الأسر .9, .9٪ حرصت على إلحاق أبنائهم بمكان للتدريب عند اكتثاف قدراتهم ومهاراتهم، ولا

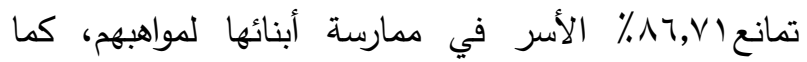

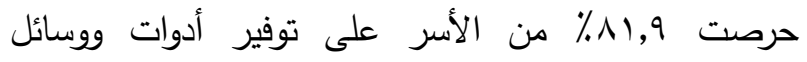

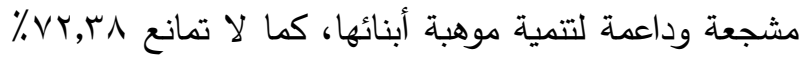

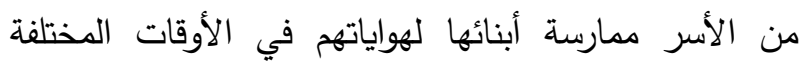
وليس في الإجازات فقط مما يساعد على تتمية مواهبهم.
ب - توافر القدوة والنموذج المشجع على الموهبة بدلالة الاتفاق في الهواية مع أفراد الأسرة: يوضح جدول (T) توزيع المبحوثين وفقا لتوافر القدوة

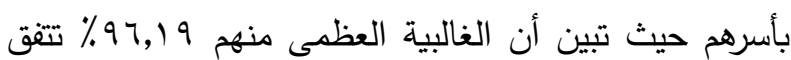
هوايتهم مع هواية فرد من أفراد الأسرة على الأقل سواء الأب

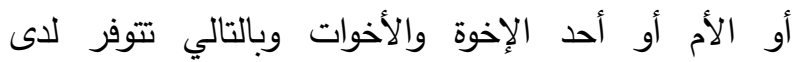
المبحوثين القدوة التي تدعمهم.

جدول ج. توزيع المبحوثين وفقا للاتفاق بين هواياتهم وهوايات أحد أفراد الأسرة

\begin{tabular}{|c|c|c|}
\hline$\%$ & العدد (ن =0 1) & البيان \\
\hline 97,19 & 1.1 & متفق فى الهواية \\
\hline$\varepsilon, \wedge 1$ & $\varepsilon$ & غير متفق فى الهواية \\
\hline $1 \ldots$ & 1.0 & المجموع \\
\hline
\end{tabular}

ويبين جدول (V) توزيع المبحوثين وفقاً للاتفاق مع هوايات أحد أفراد أسرهم حيث بينت النتائج البحثية أن ثلث

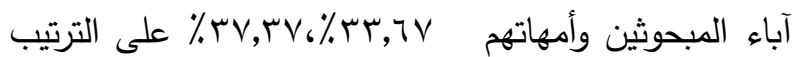
تتفق هواياتهم الثقافية مع هواية أبنائهح مما يسهح في رفع

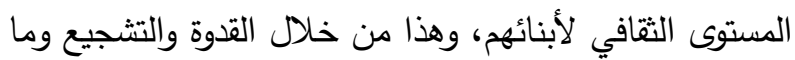

جدول V. توزيع المبحوثين وفقاً لاتفاق هواياتهم مع هوايات أحد أفراد أسرهم

\begin{tabular}{|c|c|c|c|c|c|c|}
\hline \multicolumn{2}{|c|}{ 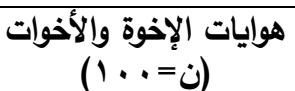 } & \multicolumn{2}{|c|}{ 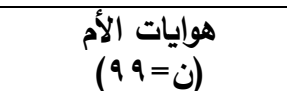 } & \multicolumn{2}{|c|}{ 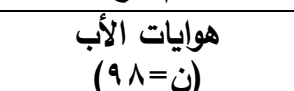 } & \multirow{2}{*}{ هوايات المبحوث هوايات أفراد الأسرة } \\
\hline$\%$ & التكرار & $\%$ & التكرار & $\%$ & التكرار & \\
\hline Y).. & YI & rV,rV & re & Tr,TV & Tr & الهواية الثقافية \\
\hline r... & 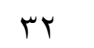 & 19,19 & 19 & १ & 19 & الهواية الفنية" \\
\hline$r \ldots$ & $r \cdot$ & $7, \cdot 7$ & 7 & IT,YV & ז & الهواية الرناضية \\
\hline$\varepsilon$. & $\varepsilon$ & $7, .7$ & 7 & 9,11 & 9 & هواية الألعاب والتسالى \\
\hline$\varepsilon$. & $\varepsilon$ & Tr,YY & rt & 0,1 . & 。 & هواية الأعمال الإنتاجية \\
\hline$\varepsilon$. & $\varepsilon$ & $r . . r$ & r & 7,14 & 7 & الهوآية العلمية \\
\hline r.. & r & $1, \cdot 1$ & 1 & 1,17 & $\wedge$ & الهواية الاجتماعية \\
\hline
\end{tabular}


جدول ^. توزيع المبحوثين وفقاً لتشجيع/تثبيط الأسرة لهج

\begin{tabular}{|c|c|c|c|c|}
\hline \multicolumn{2}{|c|}{ ע } & \multicolumn{2}{|c|}{ نعم } & \multirow[b]{2}{*}{ عوامل التشجيع/ التثبط الأسربة } \\
\hline$\%$ & 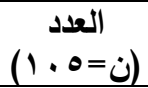 & $\%$ & 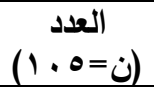 & \\
\hline $9,0 Y$ & 1 & $9 \cdot, 0$ & 90 & حرص الأسرة على إلحاق المبحوث بمكان للتدربب فيه \\
\hline $1 \wedge, 1$ & 19 & $\wedge 1,9$ & $\wedge 7$ & حرص الأسرة على توفير أدوات ووسائل لتتمية المبحوث \\
\hline$\wedge \uparrow, \vee \backslash$ & 91 & Ir, & $1 \varepsilon$ & منع الأسرة للمبحوث عن ممارسة هواياته \\
\hline$V Y, r \Lambda$ & $\mathrm{V} 7$ & $r V, T r$ & rq & السماح للمبحوث لممارسة هواياته في الإجازات فقط \\
\hline
\end{tabular}

وبسؤال المبحوثين عن من له الفضل في الارتقاء بموهبتهم

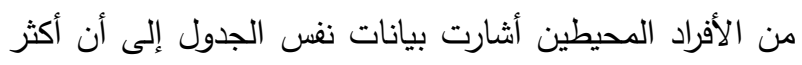

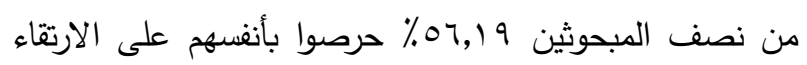

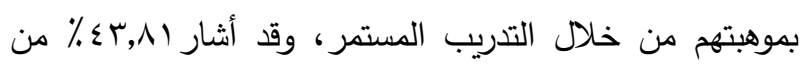

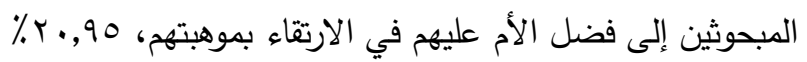

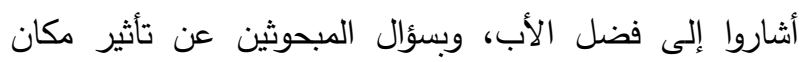

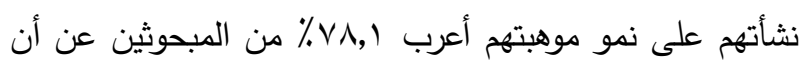

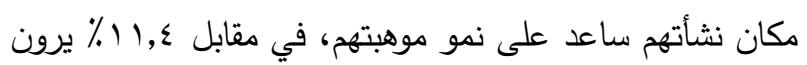

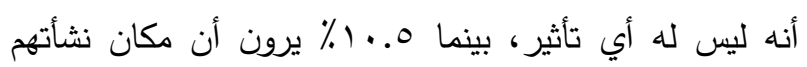
أعاق نمو موهبتهم. وبتقييم مستوى مساهمات الأسرة في تتمية قدرات ومهارات المبحوثن ومستوى الممارسات الأسرية المتبعة لتحفيز موهبتهم،

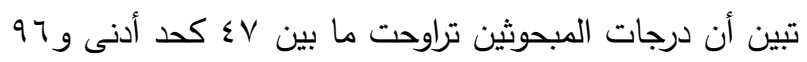

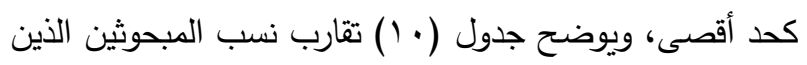

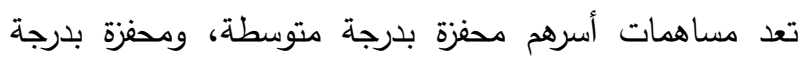

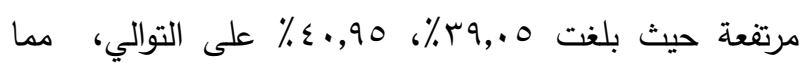

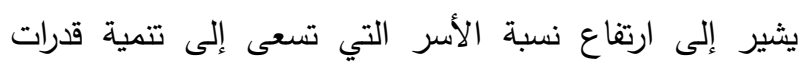

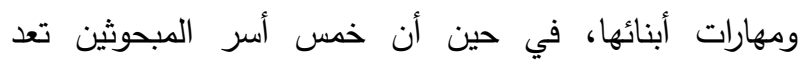

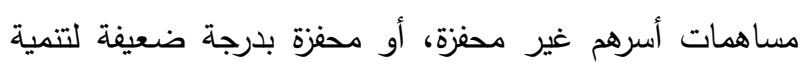

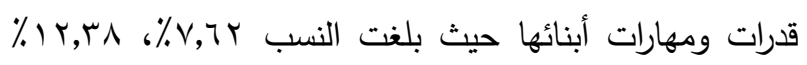

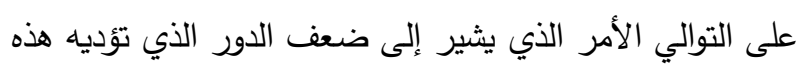

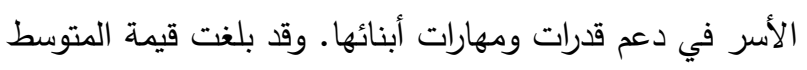

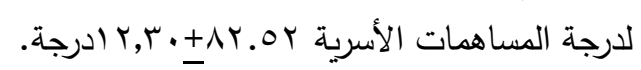

د - دور الأسرة في التأهيل العلمي والععلي في مجال

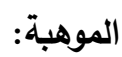

للأسرة دور هام في تتمية وتثكيل الموهبة وهذا من خلال

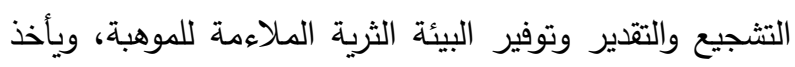
هذا الدور الداعم والمشجع شكله من خلال استدعاء متخصصين لتثقيفهم وتزويدهم بما يصقل قدراتهم، وأيضا عقد الدان

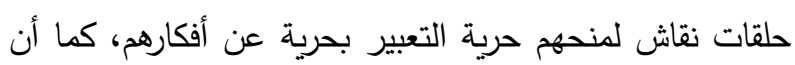

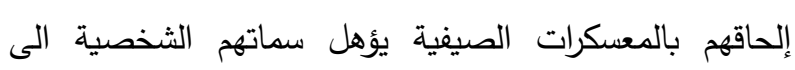

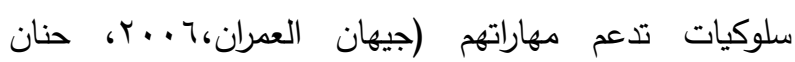

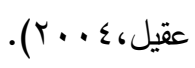
كما أن للأسرة دور في تكوين شخصية ابنها المراهق الموهوب، فمنها يستمد عاداته وتقاليده وفلسفة مجتمعه، وتكوين

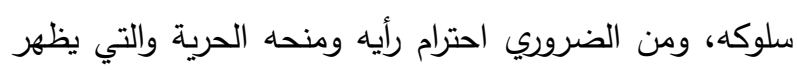

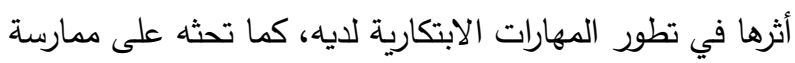

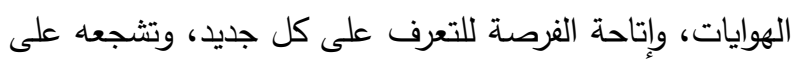
شراء الكتب المفيدة لتجعل القراءة سلوك محبب الى نفسه (حمد التعاد

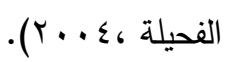
وبسؤال المبحوثين عن اهتمام أسرهم بتأهيلهم علمياً أو أو الموات

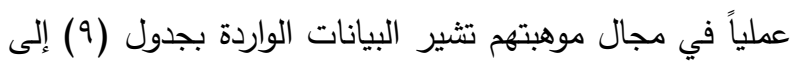

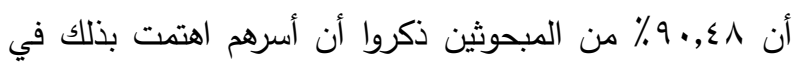

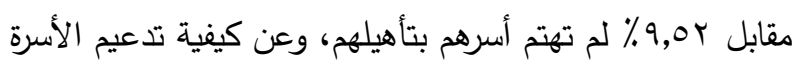

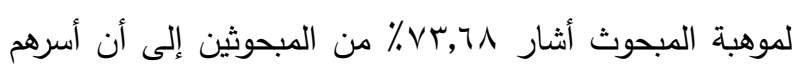

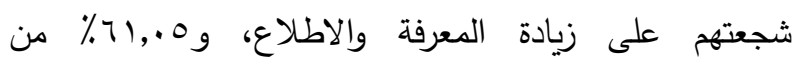

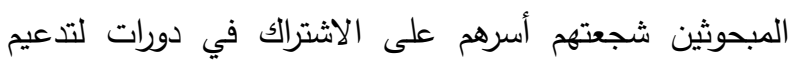

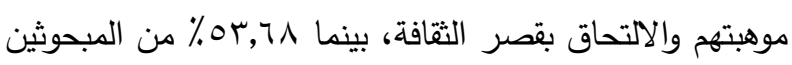
حرصت أسرهم على أن يستفيدوا من أصحاب الخبرات والمهن. 


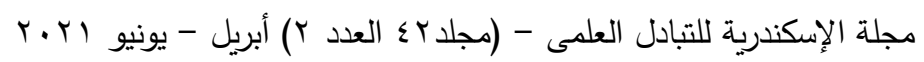

جدول 9.

\begin{tabular}{|c|c|c|}
\hline$\%$ & العدد (ن =0 ، 1 ) & البيانٍ \\
\hline & & اهتمام الأسرة بتأهيل المبحوث علمياً أُو علمياً \\
\hline$q \cdot, \leqslant \wedge$ & 90 & نعم \\
\hline $9,0 \mathrm{r}$ & 1. & $\gamma$ \\
\hline $1 \ldots$ & 1.0 & 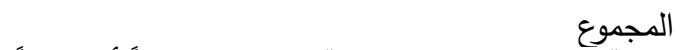 \\
\hline$\%$ & (التكرار (ن = ه 9) & كيفية الاهتمام بتدعيم موهبة المبحوث علمياً أو عملياً \\
\hline $\mathrm{V}, \mathrm{T}, \mathrm{A}$ & $v$. & دعم الموهبة بالمعرفة والاطلاع \\
\hline $71, .0$ & 01 & الدورات والتثريب بقصر الثقافة \\
\hline A & 01 & الإفادة من أصحَحاب الخبرات والمهن \\
\hline$\{0, Y \uparrow$ & $\varepsilon r$ & التحصيل العلمى (تعديل مسار الدراسة) \\
\hline$\%$ & التكرار (ن=0. 1 (1) & من له آلفضل فقى الارتقّاء بالموهبةً \\
\hline 07,19 & 09 & المبحوث نفسه \\
\hline$\varepsilon r, \wedge)$ & $\leq 7$ & الأم \\
\hline$r \cdot, 90$ & rt & الأب \\
\hline $1 \leqslant, r q$ & 10 & 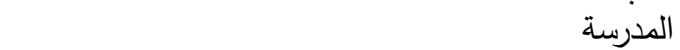 \\
\hline$V, T T$ & $\wedge$ & تأثير مكان النثشأُة على نمو الثقافة \\
\hline$\vee \wedge, 1$ & Ar & ساعد على نمو الموهبة \\
\hline $11, \varepsilon$ & ir & \\
\hline $1 ., 0$ & 11 & أعاق ندو الّوهبة \\
\hline
\end{tabular}

جدول ا ـ توزيع المبحوثين وفقاً لمستوى مساهمات الأسرة في تنمية قدراتهم ومهاراتهم وتحفيز موهبتهم

\begin{tabular}{|c|c|c|}
\hline$\%$ & العدد (ن= . ه 1 ) & البيان \\
\hline & & مستوى مساهمات الأسرة \\
\hline $\mathrm{V}, \mathrm{TY}$ & $\Lambda$ & مساهمات أسرية غير محفزة للموهبة (>VV (1> درجة) \\
\hline Ir, rN & ז & 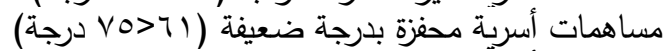 \\
\hline$r 9, .0$ & «1 & مساهمات أسرية محفزة بدرجة متوسطة (9>V0 (Aدرجة) \\
\hline$\varepsilon \cdot, 90$ & $\varepsilon r$ & مساهمات أسرية محفزة بدرجة مرتنعة (9'لدرجة فأكثر ) \\
\hline & & المتوسط والانحرراف المعياري لدرجة الدساهمات \\
\hline
\end{tabular}

الدرسية، ويعاني ثلث المبحوثين بr,rr\% من سخرية من

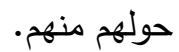

ومن جهة أخرى كثفت نتائج نفس الجدول عن مواجهة

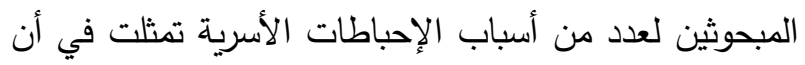

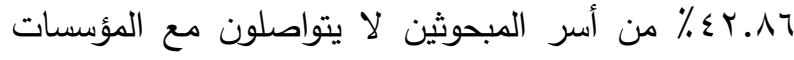

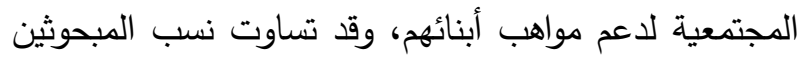

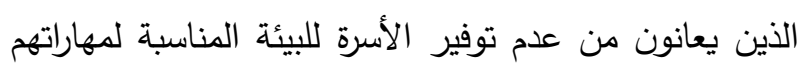

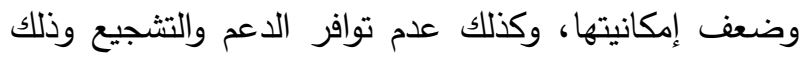

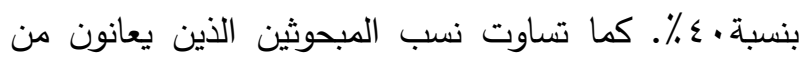

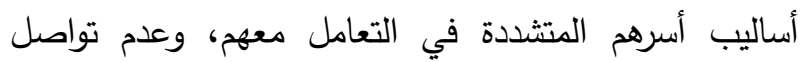

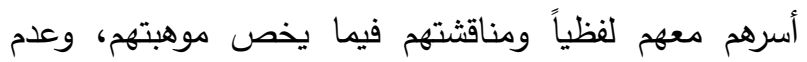

ثالثاً: الإحباطات الثخصية والأسرية التي يعاني منها المبحوثون المترددون على قصور الثقافة المدروسة: يبين جدول (1') توزيع المبحوثين وفقاً لأسباب شعورهم بالإحباطات الثخصية والأسرية حيث بينت النتائج البحثية أنه قد جاء على رأس أسباب الإحباطات الثخصية شعور

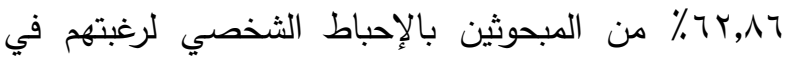

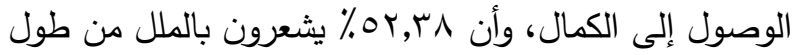

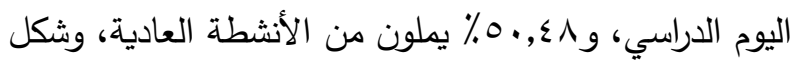

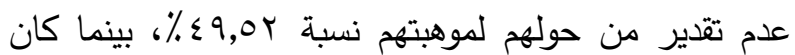

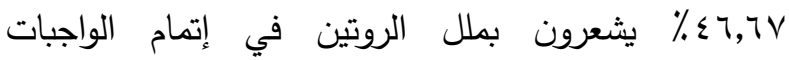


تواصل أسرهم مع المدرسة لدعم موهبتهم وذلك بنسبة على التوالي، وبلغ متوسط الدرجة الدالة على الإحباطات

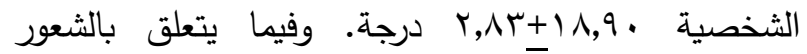
$\%$. وبتوزيع المبحوثين وفقاً لمستوى شعورهم بالإحباطات بالإحباطات الأسرية تبين أن أكثر من نصف المبحوثين

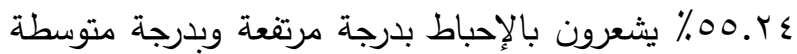
حيث بلغت النسبة ب.T.T\% لكل منهما بمتوسط قدره

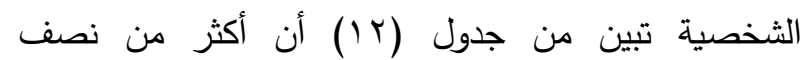
المبحوثين 19.07\% يثعرون بالإحباط الثخصي بدرجة

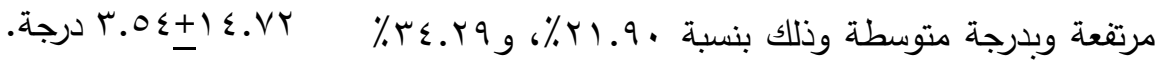
جدول الـ ـوزيع المبحوثين وفقاً لأسباب الإحباطات الثخصية والأسرية

\begin{tabular}{|c|c|c|c|c|c|}
\hline$\%$ & 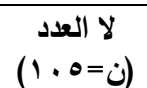 & $\%$ & 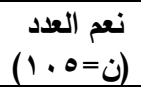 & 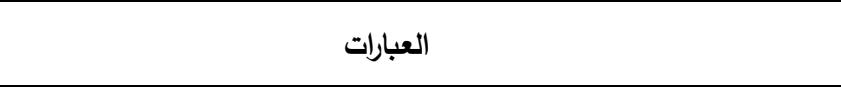 & e \\
\hline & & & & \multicolumn{2}{|c|}{ أسباب الإحباطات الثخصية } \\
\hline$r V, 1 \varepsilon$ & rq & $T 4, \Lambda 4$ & 79 & رغبتى في الوصول للكمال & 1 \\
\hline$\sum V, T Y$ & o. & Or, r & 00 & شعوري بالملل من طول اليوم الدراسي & r \\
\hline$\sum 9,0 Y$ & or & $0 ., \leqslant \wedge$ & or & الثعور بالملل من الأنشطة العادية & r \\
\hline $0,, \leqslant \wedge$ & or & $\leq 9,0$ Y & or & عدم تقدير من حولى لموهبتى & $\varepsilon$ \\
\hline שr,rot & 07 & $\leq \uparrow, \uparrow \vee$ & $\leq 9$ & شعوري بالملل من الروتين فى إتمام الواجبات المدرسية & $\circ$ \\
\hline $0 \leqslant, r q$ & ov & $\leq 0, \vee 1$ & $\sum \Lambda$ & وجود عوائق تحول دون ممارستى لموهبتى & 7 \\
\hline $7 ., 90$ & $T \varepsilon$ & rq,.० & « & عدم قبول الأوامر لتعدد أفكاري ومواهبى & $v$ \\
\hline $7 ., 90$ & $T \varepsilon$ & r9,.० & « & عدم تحقيق رغباتى & $\wedge$ \\
\hline 71,9 . & 70 & rᄉ, l. & $\varepsilon$. & زملاتئ لأنى مختلف عنهم & 9 \\
\hline $74,7 \mathrm{~V}$ & $\vee \cdot$ & 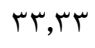 & ro & 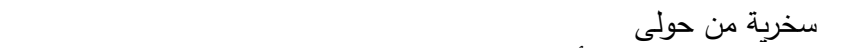 & 1. \\
\hline VY, rA & $\vee 7$ & $r V, T r$ & rq & لنىى أتجاوز عوائق الإحباط & 11 \\
\hline$V_{0, Y} \leqslant$ & vq & $r \leqslant, \vee \uparrow$ & r4 & الإحباطات الأسربة: ألدى & أسباد \\
\hline$o v, 1 \leq$ & 7. & 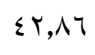 & «o & عدم وعى أسرتى بضرورة التواصل مع المؤسسات المجتمعية لدعم لموهبتى & 1 \\
\hline $7 .,$. & זיד & $\varepsilon \cdot, \cdot$ & $\leq r$ & 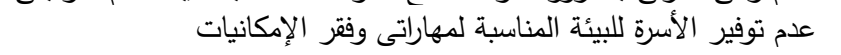 & r \\
\hline $7, \ldots$ & זיד & $\varepsilon \cdot, \cdot$ & $\varepsilon r$ & عدم توافر الدعم والتثجيع الذي يظهر موهبتى ومهاراتى & r \\
\hline $7 r, \wedge 1$ & TV & $r 4,19$ & rᄉ & أساليب أسرتي المتشددة للتعاملَ معى & $\varepsilon$ \\
\hline 7 Tr,人 & TV & $r 4,19$ & rᄉ & عدم تواصل أسرتى معى لفظيا ومناقشتى فيما يخص موهبتى & $\circ$ \\
\hline Tr,ג & TV & $r 4,19$ & ץ & عدم تواصل أسرتى مع المدرسة يقلل من إظهار مواهبى & 7 \\
\hline $70, \mathrm{~V})$ & 79 & $r \varepsilon, r q$ & r & انخفاض مستوى والدى الثقافى والتعليمى والاقتصادي & v \\
\hline$\uparrow \curlywedge, 0 \mathrm{~V}$ & vr & $r_{1, \varepsilon r}$ & r & مساواة أُسرتى لى بإخوتى العاديين وعدم تفهم موهبتى & $\wedge$ \\
\hline $79,0 Y$ & VT & $r \cdot, \leqslant \Lambda$ & rt & كثرة المشكلات في أسرتى وعدم استقرارها & 9 \\
\hline
\end{tabular}

جدول rا 1. توزيع المبحوثين وفقاً لمستوى شعورهم بالإحباطات الثخصية والأسرية

\begin{tabular}{|c|c|c|c|}
\hline \multirow[t]{2}{*}{$\%$} & ن= العدد & \multicolumn{2}{|r|}{ 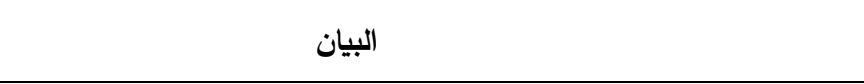 } \\
\hline & & & مستوى الثعور بالإحباطات الثخصية: \\
\hline r, 9. & rt & & الثعور بدرجة مرتفعة من الإحباط (r ا V> ادرجة) \\
\hline$r \leqslant, r q$ & r & & الثعور بدرجة متوسطة من الإحباط (> V V ا بدرجة) \\
\hline$\{r, \wedge)$ & $\leq 7$ & & الثعور بدرجة منخفضة من الإحباط ( (r درجة فأكثر) \\
\hline & & $r, \wedge r_{-} \backslash \wedge, q$. & المتوسط والانحرر بالإحباطات المعياري \\
\hline rV.TT & rq & & الثعور بدرجة مرتفعة من الإحباط (9 > ادرجة) \\
\hline rV.TT & rq & & الثعور بدرجة متوسطة من الإحباط (r lV> IV درجة) \\
\hline$\varepsilon \varepsilon . \vee 4$ & $\varepsilon V$ & & الشعور بدرجة منخفضة من الإحباط (V ل درجة فأكثر ) \\
\hline & & $r .0 \leq+1 \leq . V Y$ & المتوسط والانحراف المعياري \\
\hline
\end{tabular}


وقد اتقق هذا البحث مع دراسة ليلى كرار (ع . ب) والتي هدفت للكثف عن الخصائص السلوكية للمتفوقين عقليا وطبقت على (•؟Y) طالباً وطالبة بمرحلة المراهقة بولاية

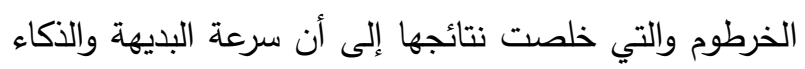

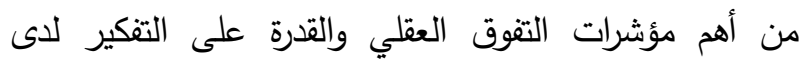

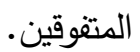

وبتقييم المبحوثين وفقاً للجانب الاجتماعي لديهم يتضح

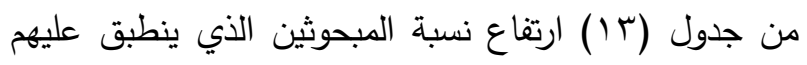
تماماً أو ينطبق عليهم لحد ما بعض السمات ومنها: التكيف التهات

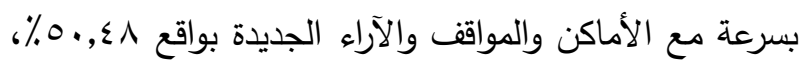

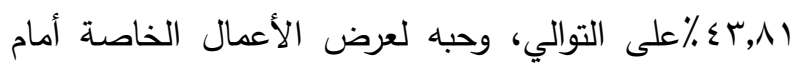

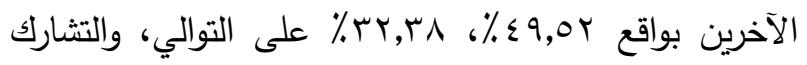

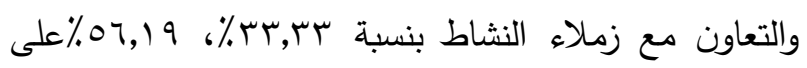

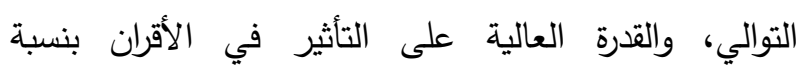

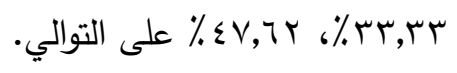
وبتقييم المبحوثين وفقاً لسمة الابتكار تبين نتائج جدول (r (T) اقتراب نصف عدد المبحوثين ممن تنطبق عليهم تماماً

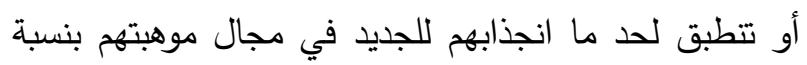

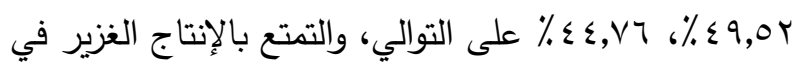

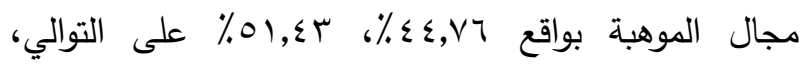

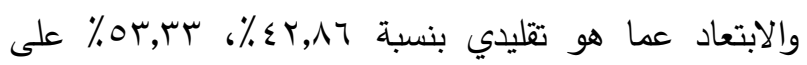

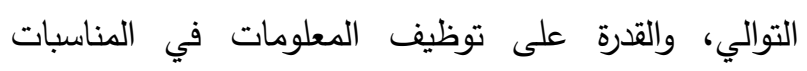

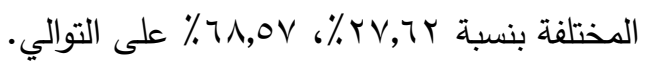

وفي هذا الصدد أظهرت دراسة سامر عياصرة، ونور

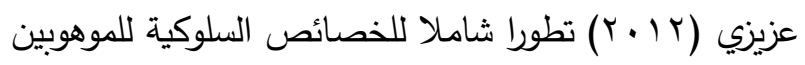

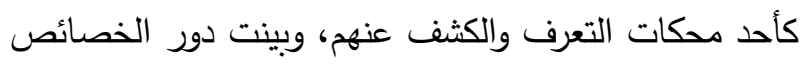
السلوكية من خلال التقدير في عملية الكثف عن الكئف دور الكوهوبين وعرضت نموذجاً تطبيقياً لتقدير السمات السلوكية العامة للطلبة الموهوبين محاولين الوقوف على بيان أهيتها وتأثيرها المباشر على تصميم برامج الموهبة والتنوق.
رابعاً تقييم درجة الموهبة للمبحوثين من خلال الخصائص

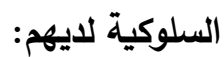
يعد تقييم الخصائص السلوكية الميزة للموهوبين من

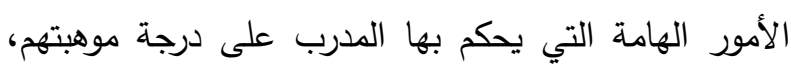

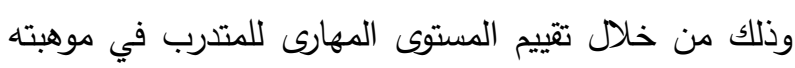

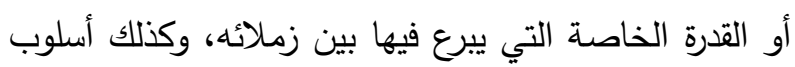

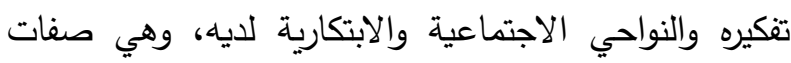
تميز الفرد أو تصف سلوكه وتظهر من خلادئل والاتكاربة الآراء والتصرفات في المواقف المختلفة (مشاري الدهام، ب ا ـ ץ). وبدراسة الخصائص السلوكية للمبحوثين للحكم على درجة

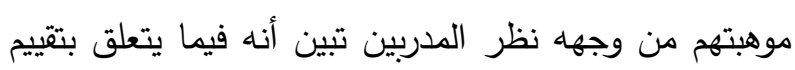
الدربين للموهبة الخاصة بالمتدربين وكما يتضح من النئ النتائج

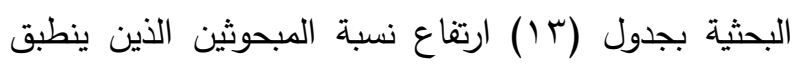

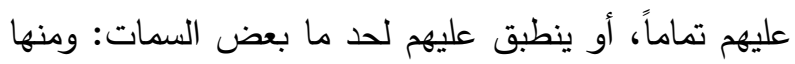

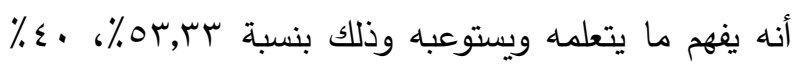

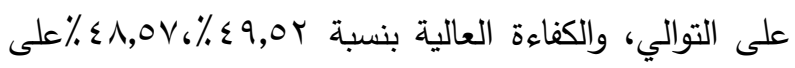

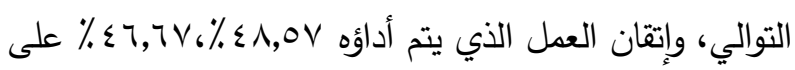

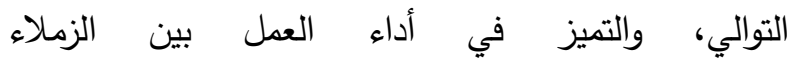

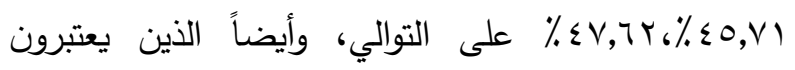

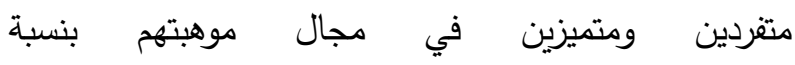

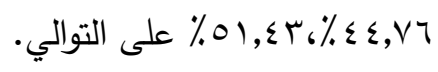
وفيما يتعلق بأسلوب تفكير المبحوثين يلاحظ من جدول

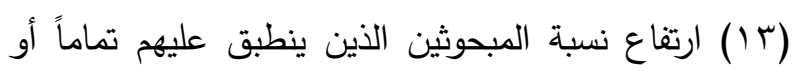

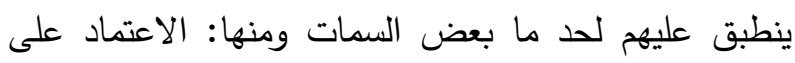

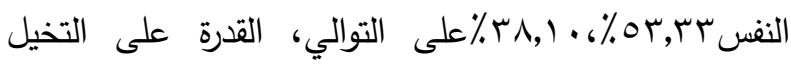

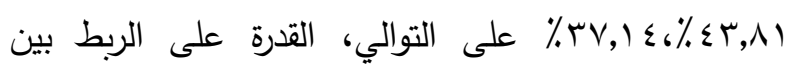

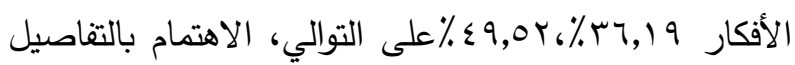

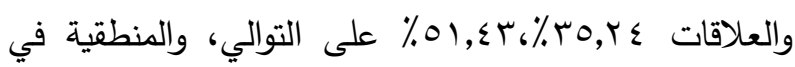

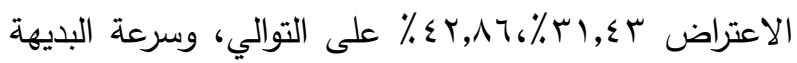

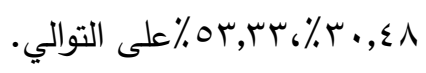


وبتقييم الخصائص السلوكية لدى المبحوثين للحكم على وبتقسيم المبحوثين وفقاً لمستوى موهبتهم تبين أن أكثر من

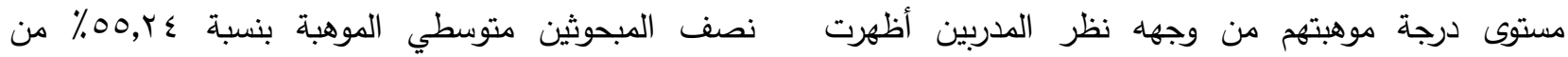
النتائج البحثية بجدول (ع () أن درجات المبحوثين - وفقاً وجهة نظر المدرب، وأكثر من خمس المبحوثين مرتفعي

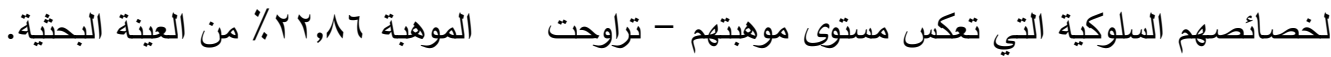

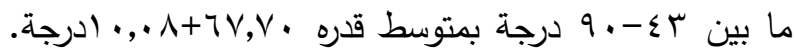

\begin{tabular}{|c|c|c|c|c|c|c|c|}
\hline \multicolumn{2}{|c|}{ لا تنطبق } & \multicolumn{2}{|c|}{ تنطبق لحد ما } & \multicolumn{2}{|c|}{ تنطبق تماماً } & \multirow[b]{2}{*}{ 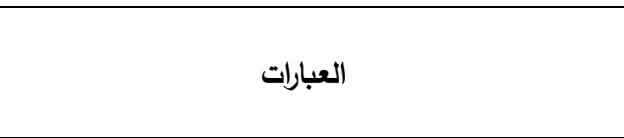 } & \multirow[b]{2}{*}{ م } \\
\hline \multirow[t]{2}{*}{$\%$} & ن= العدد 1. & $\%$ & ن= العدد 1. & $\%$ & ن=8 العدد 1 . & & \\
\hline & & & & & & \multicolumn{2}{|c|}{ المهارة في الموهبة: } \\
\hline T,TV & $\checkmark$ & $\varepsilon \cdot, \cdots$ & $\leqslant r$ & 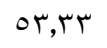 & 07 & يفهح ما يتعلم ويستوعبه & 1 \\
\hline 1,9 & r & $\varepsilon \wedge, O V$ & 01 & $\leqslant 9,0 \mathrm{r}$ & or & لديه كفاءة عالية & r \\
\hline$\varepsilon, \vee \uparrow$ & 0 & $\varepsilon 7,7 \vee$ & $\leq 9$ & $\varepsilon \wedge, 0 \vee$ & 01 & يتقن ما يفعله أو يؤديه & r \\
\hline $7, \mathrm{TV}$ & v & $\varepsilon V, T r$ & o. & $\leq 0 . v 1$ & $\varepsilon \wedge$ & أداؤه متميز بين زملائه & $\varepsilon$ \\
\hline$r, \wedge)$ & $\varepsilon$ & $01, \varepsilon r$ & $0 \leqslant$ & $\varepsilon \varepsilon, \vee \uparrow$ & $\varepsilon V$ & يعتبر متفردا ومتميزاً في مجال موهبته & ○ \\
\hline 1,9 & r & $71,9$. & 70 & r.,19 & r人 & يمتلك خصائص وسماتِ قد لا يمتلكها الأخرون & 7 \\
\hline $0, \times 1$ & 7 & $71,9$. & 70 & 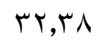 & $r \varepsilon$ & يتوافر لدية السرعة والبراعة فى أداء المهمة & $\checkmark$ \\
\hline$\Lambda, O \mathrm{~V}$ & 9 & $7 ., 90$ & $T \varepsilon$ & $r \cdot, \leqslant \Lambda$ & r & يتصف بمهارة عالية في الأداء & $\wedge$ \\
\hline Ir,r & ir & $o v, 1 \leq$ & 7. & $r \cdot, \Sigma \wedge$ & re & يقوم بمهام صعبة بالنسبة لزملائه & 9 \\
\hline 9,0 Y & 1. & $71,9$. & 70 & Y^,OV & r. & يتصف أداؤه بالسهولة والدقة & 1. \\
\hline & & & & & & التفكير : & أسلود \\
\hline 1.0V & 9 & rᄉ.l. & $\varepsilon$. & Tr. & 07 & يعتمد على نفسه & 1 \\
\hline $19 . .9$ & $r$. & MV.l & rq & $\varepsilon r . \wedge 1$ & $\leqslant 7$ & لديه القدرة على التخيل & r \\
\hline $1 \leq . r q$ & 10 & $\varepsilon 9.0 r$ & or & r..19 & rی & يستطيع الربط بين الأفكار & r \\
\hline אז.זו & $1 \varepsilon$ & $01 . \leqslant r$ & $0 \leqslant$ & To.rs & rv & يهتم بالتتفاصيل والعلاقات & $\varepsilon$ \\
\hline$r v . v i$ & $r v$ & 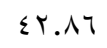 & $\leq 0$ & M. & 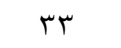 & منطقى فى اعتراضاته & 0 \\
\hline 17.19 & iv & איזם & 07 & $r \cdot . \Sigma \wedge$ & r & يمتاز بسرعة البديهة & 7 \\
\hline rV.tr & rq & $\varepsilon \wedge .0 \mathrm{~V}$ & 01 & rt.人i & ro & يتمتع بقدرة مرتفعة على التفكير الناقد & $v$ \\
\hline rY.AT & $r \varepsilon$ & $0 \wedge .1$. & 71 & 19.00 & r. & قادر على اقتراح حلول بديلة صائبة & $\wedge$ \\
\hline Yr.AT & $r \varepsilon$ & Tr.AT & 77 & $1 \leq .49$ & 10 & يمتلك قدرة متميزة فى الحكم على الأمور & 9 \\
\hline & & & & & & الاجتماعية: & الجواة \\
\hline $0, \times 1$ & 7 & $\varepsilon r, \wedge 1$ & $\leq 7$ & $0 ., \leqslant \wedge$ & or & يتكيف بسرعة مع الأماكن والمواقف والآراء الجديدة & 1 \\
\hline $1 \wedge, 1$ & 19 & H, זA & $r \varepsilon$ & $\leqslant 9.0 r$ & or & محب لعرض أعماله أمام الآخرين & r \\
\hline $1 \cdot . \leqslant \Lambda$ & 11 & 07.19 & 09 & 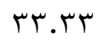 & ro & يشارك ويتعاون مع زملاء النشاط & r \\
\hline $19 . .0$ & $r$. & $\sum V . T r$ & o. & 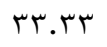 & ro & لديه قدره عالية على التأثير على أقرانه & $\varepsilon$ \\
\hline Tre & $1 \varepsilon$ & $00 . Y \leq$ & 01 & T. I. & r & يحسن الاستماع والتواصل مع الآخرين & 0 \\
\hline & & & & & & الابتكارية: & 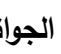 \\
\hline $0, \times 1$ & 7 & $\varepsilon \varepsilon, \vee \uparrow$ & $\varepsilon \vee$ & $\varepsilon 9,0 \mathrm{r}$ & or & يجذبه آلجديد في مجال موهبته & 1 \\
\hline$r, \wedge)$ & $\varepsilon$ & $01, \varepsilon r$ & $0 \leqslant$ & $\varepsilon \varepsilon, \vee \uparrow$ & $\varepsilon \vee$ & يتمتع بإنتاج غزير فى مجال موهبته & r \\
\hline r.A & $\varepsilon$ & איזם & 07 & $\sum Y . \wedge T$ & «o & يبتعد عن تكرار ما هو تقليدي & r \\
\hline r.A & $\varepsilon$ & $7 \wedge .0 \mathrm{~V}$ & Vr & rV.tr & rq & قادر على توظيف معلوماته فِى المناسبات المختلفة & $\varepsilon$ \\
\hline ᄉ.. V & 9 & $T \leq . V T$ & 71 & r..7V & rA & يعطى أفكار أصيلة وحلولا جديدة غير مُألوفة & ○ \\
\hline $0 . v 1$ & 7 & $71.0 \mathrm{~V}$ & Vr & ro.vi & rV & منتج ولديه القدرة على مواصلة العمل في المهام الصعبة & 7 \\
\hline
\end{tabular}




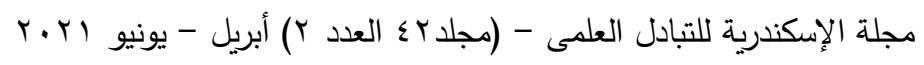

جدول ؛ ا ـ توزيع المبحوثين وفقاً لمستوى درجة موهبتهم بناءً على خصائصهم السلوكية من وجهة نظر المدربين

\begin{tabular}{|c|c|c|}
\hline$\%$ & العدد (ن=0 • 1 () & مستوى درجة الموهبة \\
\hline$r, 9$. & Tr & منخفض الموهبة (ץ|>. Tدرجة) \\
\hline $00, Y \varepsilon$ & 01 & متوسط الموهبة(.. VV>> درجة) \\
\hline r T,AT & $r \varepsilon$ & المتتوسط الموهبة (لانحراف المعيلة فاكثر) \\
\hline
\end{tabular}

أن أكثر من ثلاثة أرباعهم 9 1, 1\% مستوى تقديرهم لذاتهم

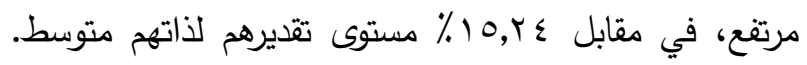
وتثير تلك النتائج الى أن مستوى السمات ليس متثابها لاى

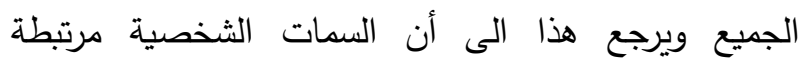

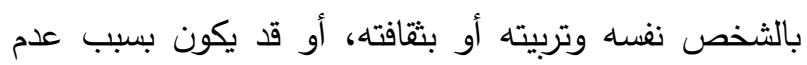
توفر التعزيز المناسب لتتمية هذه السمات وتطويرها.

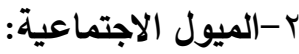

من نتائج جدول (10) يلاحظ أن غالبية المبحوثين لديهم ميول اجتماعية عالية حيث يثارك ــ, . 9 \% منهم أصدقائهر

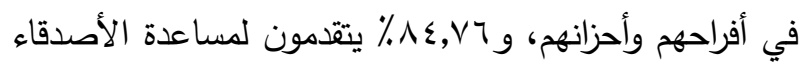

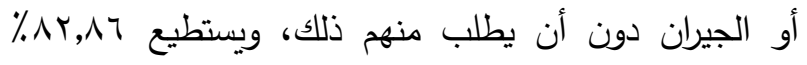
منهم تكوين صداقات جديدة بسهولة، كما يفضلون الانتماء

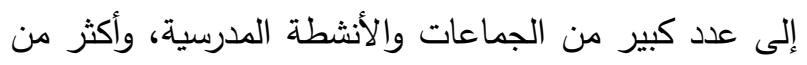
ثلاثة أرباع المبحوثين يستطيعون فهم مشاعر الآخرين دون

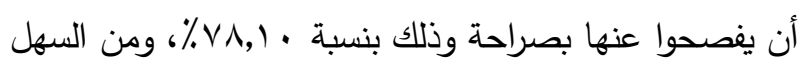
على 9 , 1.V7 منهم بدء الحديث مع الأشخاص الغرباء. وبتقييم مستوى الميول الاجتماعية لاى المبحوثين تبين من

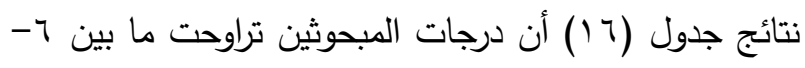

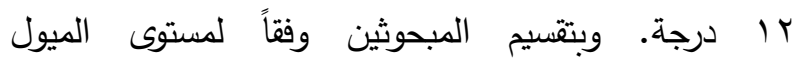

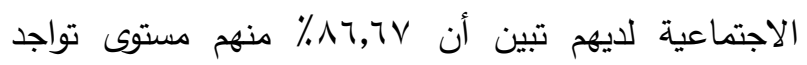
الميول الاجتماعية لديهم مرتفع. وهذه النتائج تعد مؤشراً جيداً

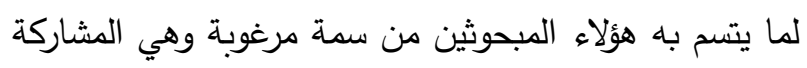

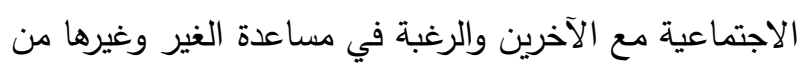

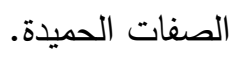

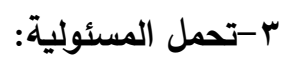

أظهرت نتائج جدول (10) ارتفاع نسبة المبحوثين الذين
خامساً السمات الثخصية المميزة للمراهقين الموهوبين

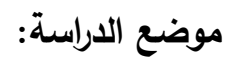

يتمتع الموهوبون بسمات عديدة تميز شخصيتهم مما يجعلهم ذوي صفات قيادية، ويسعون لمناشدة الكمال،

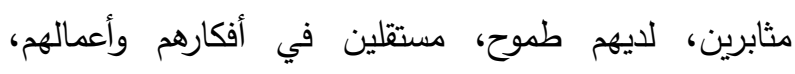

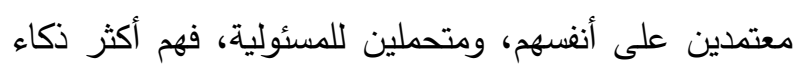

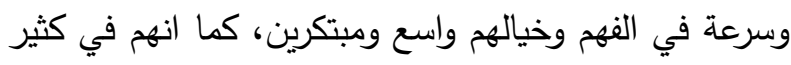
من الأحيان متعاونين، وفي الدقابل قد نجدئ والهم أكثر قلقاً وانفعالاً، وانطوائية، خجولين أحياناً، ومتمردين أحياناً أخرى وهذا بحكم مرورهم بمرحلة الرراهقة والتي تكثر فيها العديد

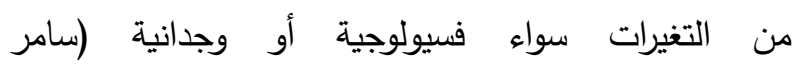

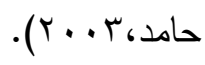

وبدراسة إجابات الدبحوثين على العبارات التي تعكس

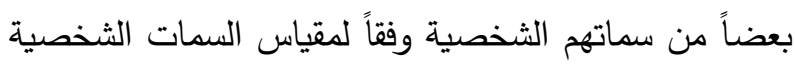

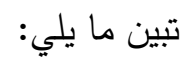

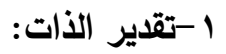

أشارت النتائج البحثية بجدول (10) ارتفاع نسبة

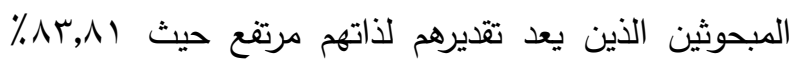
منهم يشعرون بقدرتهم على تحقيق الأثياء التي يريدونها،

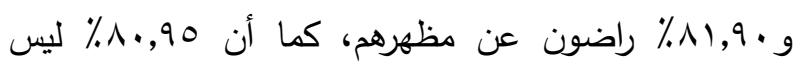

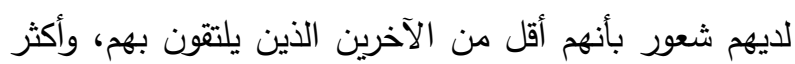

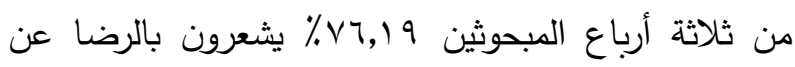

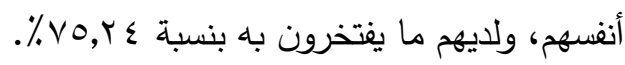
وبتقييم مستوى تقدير الذات لاى المبحوثين تبين من نتائج جدول (17) أن درجات المبحوثين تراوحت ما بين درجة وبتقسيم المبحوثين وفقاً لمستوى تقدير الذات لديهم تبين 


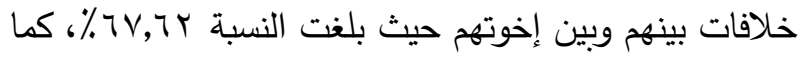

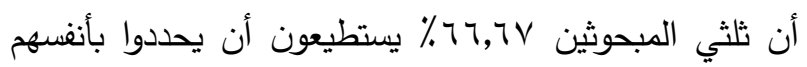

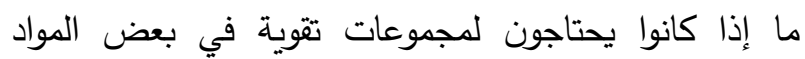

وبتقييم مستوى الاستقلالية لدى المبحوثين تبين من أوضحت النتائج ب جدول (T (1) أن درجات المبحوثين

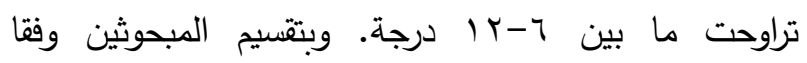

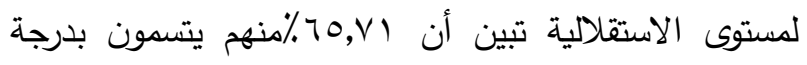

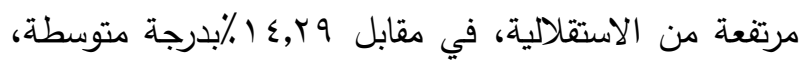

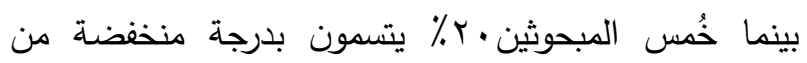
الاستقلالية.

تتفق نتائج الدراسة الحالية مع نتائج دراسة رنا السلعوس

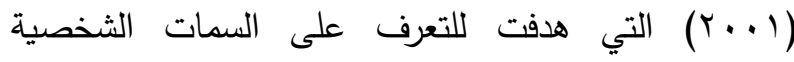
للمتفوقين حيث ثبت أنهم بثكل عام أكثر ذكاء واستقلالية وهذا يشير إلى أن الموهوبين المتفوقين أكثر قدرة على ضبط النفس وأكثر إيجابية ولا يقبلون التقليد أو التبعية. ومستقلين في أفكارهم وأعمالهم مجددين ومبتكرين لما يمتلكونه من خبرات تمكنهم من تحقيق طموحاتهم وتعد هذه السمات مؤشراً لتمتعهم بالذكاء الانفعالي. צ- - السلوك التوكيدي:

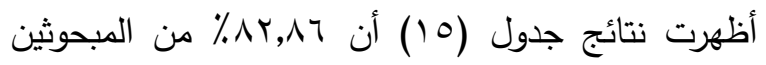
يمكنه عرض وجهه نظرهم التي تخالف ما يراه الآخرين بطريقة حسنة، وتساوت نسبة من يدافعون عن أنفهه إذا

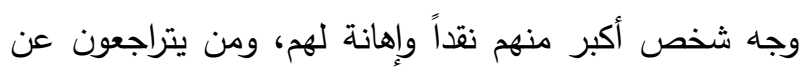

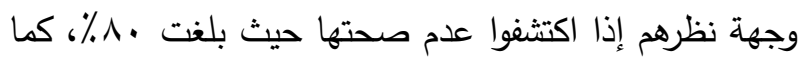

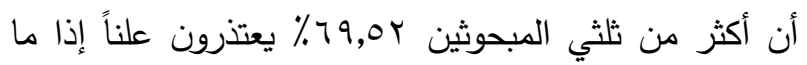

$$
\text { أخطأوا في حق زميل لهم. }
$$

وبتقييم السلوك التوكيدي لدى المبحوثين تبين من نتائج

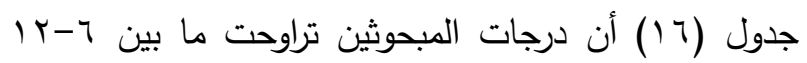
درجة. وبتقسيم المبحوثين وفقاً لمستوى السلوك التوكيدي

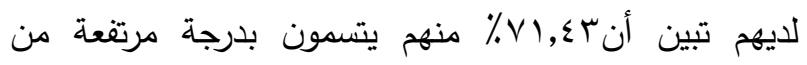

يرون أنه من الواجب على كل شخص أن يفي بوعده

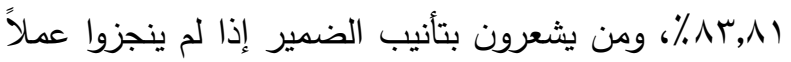

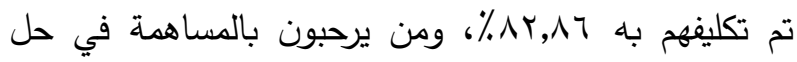

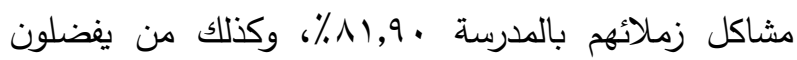

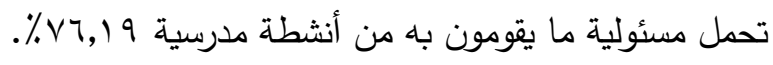
وبتقييم مستوى تحمل المسئولية لدى المبحوثين تبين

من نتائج جدول (7 ا) أن درجات المبحوثين تراوحت ما بين 1 ا I درجة. وبتقسيم المبحوثين وفقاً لمستوى تحمل

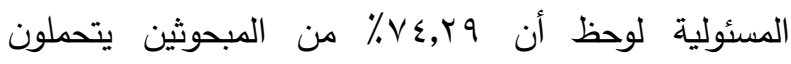

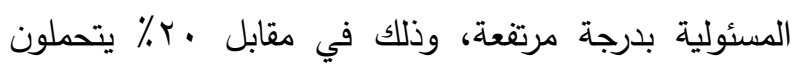
المسئولية بدرجة متوسطة. ع - عقلانية السلوك: من النتائج البحثية بجدول (10) وجد أن ای,ب^٪ من المبحوثين لا يتسرعون في الحكم على الأفراد الآخرين قبل

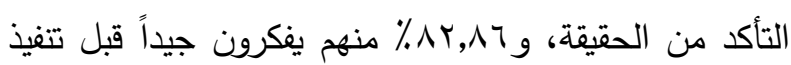

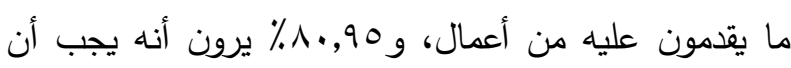
يتروى الشخص قبل أن يخالف الجماعة إذا اتخذت قراراً، كما

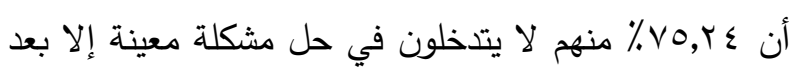
أن يكونوا فكرة تامة عنها.

وبتقييم مستوى عقلانية السلوك لدى المبحوثين تبين من نتائج جدول (7 (1) ومن خلال النسب السابقة يتضح عقلانية السلوك لدى نسبة مرتفعة منهم. وقد تراوحت درجات عقلانية السلوك ما بين ج-r إ درجة. وبتقسيم المبحوثين وفقاً لمستوى عقلانية السلوك لديهم

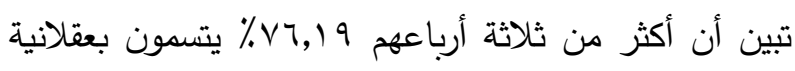

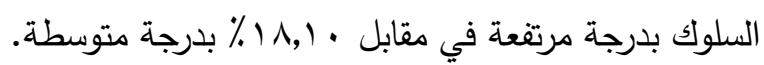

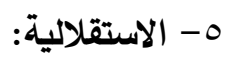
أشارت النتائج البحثية بجدول (0 1) إلى أن ثلاثة أرباع

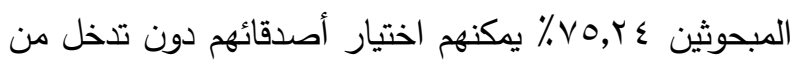
أحد، وتساوت نسبة من يقومون بممارسة هواياتهم الخاصة دون تدخل من أحد، ومن يترك لهم حرية التصرف لإنهاء أي 


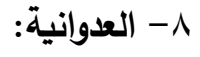
تبين من نتائج جدول (10) أن أكثر من ثلث المبحوثين

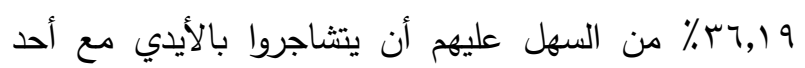
الأشخاص، ولا يترددوا في الكثف عن عيوب الثخص أمام

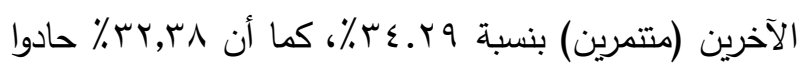
الطباع في تصرفاتهم. وبتقييم مستوى العدوانية لدى المبحوثين تبين من نتائج

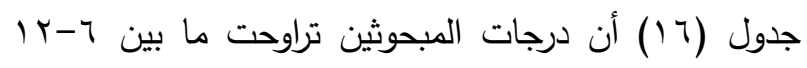
درجة. وبتقسيم المبحوثين وفقاً لمستوى العدوانية لديهم تبين

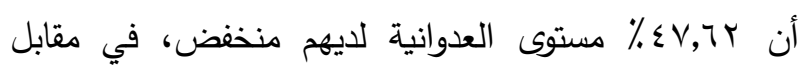

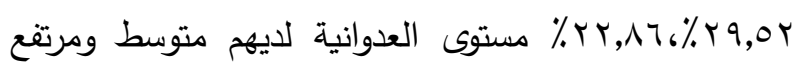
على التوالي. 9 - 2 - 2 - العصابية: أشارت النتائج البحثية بجدول (10) إلى ارتفاع نسبة

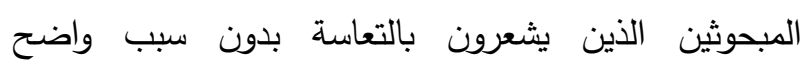

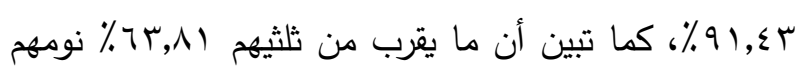

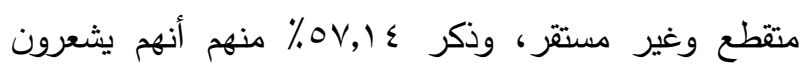
بالضيق من الإحساس بالنقص، ويشعرون بالأذى حينما يجد

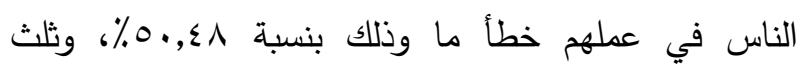
المبحوثين يصفون أنفسهم بأنهم سريعوا الاستثارة والغضب

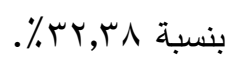
وبتقييم مستوى العصابية لدى المبحوثين تبين من نتائج

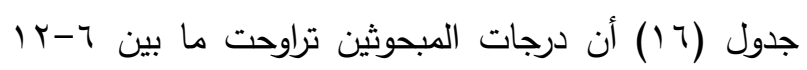
درجة. وبتقسيم المبحوثين وفقاً لمستوى العصابية لديهم تبين

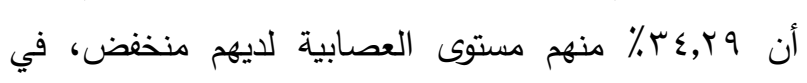

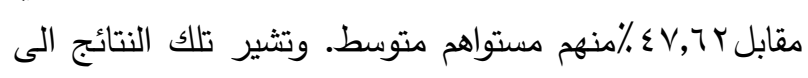

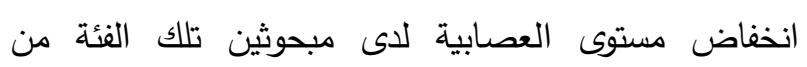
المراهقين مما يفسر تمتعهم بالهدوء والتأني في تعاملاتهم. . 1 - المستوى العام للسمات الشخصية:

بتقييم المبحوثين وفقاً للمستوى العام في السمات الثخصية تبين من نتائج جدول (7 ا ) أن درجات المبحوثين تراوحت ما
السلوك التوكيدي، في مقابل 0 ., 1 ٪ منهم يتسمون بدرجة متوسطة من السلوك التوكيدي.

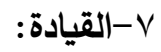
من النتائج البحثية بجدول (10) تبين تساوى نسبة المبحوثين الذين يقومون بدور قيادي في معظم الوقت بين

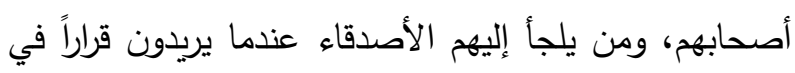
بعض أمورهم وذلك بنسبة 90, ، ٪٪، كما أن أكثر من ثلاثة أرباع المبحوثين عV,1\% يشعرون أن شخصيتهم تترك أثراً في نفس زملائهم وأصحابهم، ولا يشعرون بأي ارتباك إذا

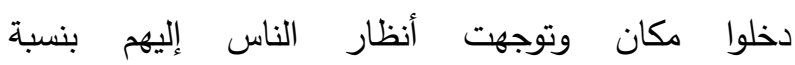

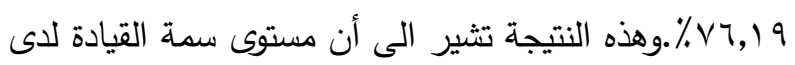
المبحوثين مرتفع ويفسر هذا بتمتع تلك الفئة من المبحوثين بقدر من الذكاء اللغوي والاجتماعي. وبتقييم مستوى القيادة لدى المبحوثين تبين من نتائج جدول (7 أ) أن درجات

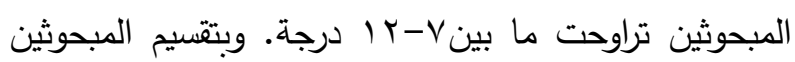

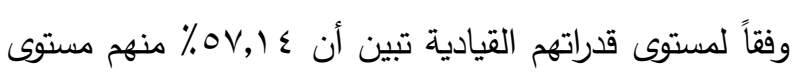
قدراتهم القيادية مرتفع، في مقابل رץ,ץץ\% مستوى قدراتهم متوسط. Smyth \& واتفقت نتائج الدراسة الحالية مع نتائج دراسة Ross (1999) والتي هدفت الى استكثاف مهارة القيادة لدى الطلاب الموهوبين لعينة مكونة من (ON) طالب من ثلاث مدارس بمدينة تورنتو بكندا، حيث تبين أن القيادة تظهر مهربه

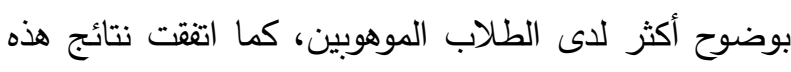
الدراسة مع دراسة (2006) Chan والتي هدفت إلى الكثف عن السمات الثخصية لدى عينة من الموهوبين المراهقين(· (0) بهونج كونج بالصين حيث أظهرت أن الموهوبين ذوى الصفات القيادية أظهروا تفوقاً في نتائج الاختبارات الثفوية، ولديهم مرونة في القيادة وقدرة على لئ توجيه الهدف والوصول إلى الكفاءة الذاتية أكثر من العاديين وهذا يؤكد تمتعهم بالذكاء اللغوي والاجتماعي. 
بين § 1-V • ا درجة، وبتقسيم المبحوثين وفقاً للمستوى العام الفئة من المبحوثين الموهوبين متمتعون بإيجابيات في سماتهم في السمات الثخصية تبين أن أكثر من نصف المبحوثين مجتمعة حيث جاءت في العموم مرتفعة حتى سمتي العدوانية ع r \% \% منهم المستوى العام لسمات شخصياتهم متوسط، والعصابية جاءتا منخفضتين مما يحقق لهم الثخصية المتزنة

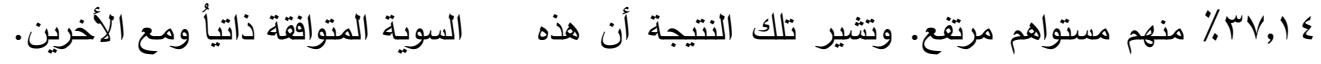

جدول ه ا ـ توزيع المبحوثين وفقاً للسمات الشخصية المميزة لهم

\begin{tabular}{|c|c|c|c|c|c|}
\hline \multicolumn{2}{|c|}{ ע } & \multicolumn{2}{|c|}{ نعص } & \multirow[b]{2}{*}{ 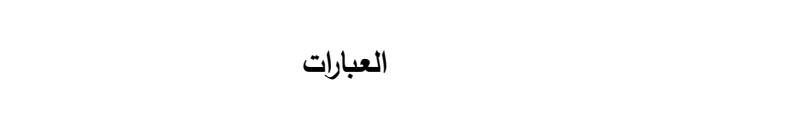 } & \\
\hline$\%$ & العدد & $\%$ & العدد & & \\
\hline & & & & & تقدير \\
\hline 17,19 & iv & $\wedge r, \Lambda)$ & 1 & أتصور أنى قادر على تحقيق الأشياء التي أربدها & 1 \\
\hline $\mid \Lambda, 1$. & 19 & $\wedge 1,9$. & 人т & أتصور أننى راض عن مظهري & r \\
\hline ᄉ., 90 & 10 & $19, .0$ & r. & لدى شعور بأنى أقل من الآخرين الذين ألتقى بهم & r \\
\hline$\vee 4,19$ & A. & $r+\Lambda$, & ro & أشعر بعدم الرضا عن نفسى & $\varepsilon$ \\
\hline Vo,r,$\varepsilon$ & vq & $r \leq, V T$ & דיץ & ليس لدى ما أفتخر به & ○ \\
\hline $7 \uparrow, 0 \mathrm{~V}$ & vr & ए, & 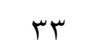 & 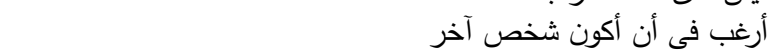 & 7 \\
\hline 9,0 r & 1. & $9 \cdot, \wedge \leq$ & 90 & أشارك أصدقائي فى أفراحهم وأحزانهم & $\mathrm{v}$ \\
\hline $10, r \varepsilon$ & 17 & $\wedge \leq, \vee \uparrow$ & 19 & أتقدم لمساعدة الأصدقاء أو الجيران دون أن يطلبوا منى & $\wedge$ \\
\hline $\mid V, I \varepsilon$ & 11 & $\wedge r, \wedge т$ & $\Lambda \vee$ & أستطيع أن أكون صداقات جديدة بسهولة & 9 \\
\hline $\mid V, I \leq$ & 11 & $\wedge r, \wedge T$ & $\Lambda \vee$ & أفضل أن أنتمى إلى عدد كبير من الجماعات والأنثطة المدرسية & 1. \\
\hline r 1,9 . & r & $\vee \wedge, 1$. & Ar & أستطيع أن أفهم مشاعر الآخرين دون أن يفصحوا عنها بصراحة & 11 \\
\hline $1 \wedge, 1$. & 19 & $v 7,19$ & $\wedge$. & على أن أبدأ حديثاً مع أشخاص غرباء & ir \\
\hline 17,19 & iv & $\wedge r, \wedge)$ & $\wedge \wedge$ & أرى أنه من الواجب على كل شخص أن يفى بوعده & 14 \\
\hline $\mid V, I \leqslant$ & 11 & $\wedge r, \wedge т$ & $\Lambda \vee$ & يؤنبنى ضميري إذا لم أنجز عملاً كلفت به & $1 \leqslant$ \\
\hline $1 \wedge, 1$. & 19 & $11,9$. & $\wedge 7$ & أرحب بالمساهمة فى حل مشاكل زملائى بالمدرسة & 10 \\
\hline$r r, \Lambda$ & ro & $v 7,19$ & $\wedge$. & أفضل أن أتحمل مسئولية ما أقوم به من أنشطة مدرسية & 17 \\
\hline$r \wedge, 1$. & $\varepsilon$. & $71,9$. & 70 & أميل إلى تحمل مسئولية الأشخاص الآخرين & iv \\
\hline 79,0 r & vr & $r \cdot, \varepsilon \wedge$ & re & أرهق نفسى أحياناً بأن أتعهد بعمل أمور كثيرة جداً & 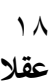 \\
\hline 17,19 & iv & $\wedge r, \Lambda)$ & $\Lambda \Lambda$ & لا أحكم على الأفراد الآخرين قبل أن أتأكد من الحقيقة & 19 \\
\hline $\mid V, I \leq$ & 11 & $\wedge r, \wedge T$ & $\Lambda \vee$ & أفكر جيداً قبل تنفيذ ما أقدم عليه من أعمال & r. \\
\hline $19, .0$ & r. & $1 \cdot, 90$ & 10 & إذا اتخذت الجماعة قراراً يجب على الثخص أن يتروى قبل أي مخالفة & r) \\
\hline$r \leq, V \uparrow$ & r & $\vee 0, r \leq$ & $\vee q$ & لا أتدخل فى حل مشكلة معينة قبل أن أكون قد كونت فكرة تامة عنها & rr \\
\hline tV,T & rq & $V T, \Gamma \wedge$ & V4 & أحب أن أعرف معلومات كافية عن كل رحلة أو حفلة أشترك فيها & r \\
\hline אז,rזr & ro & $77,7 \vee$ & $\vee \cdot$ & بعمل أفكر فى رد فعل أصدقائى & $r \varepsilon$ \\
\hline$r \varepsilon, T V$ & r & $V 0, Y \leq$ & $\vee 9$ & أَختار أصدقائى دون تدخل من أحد & ro \\
\hline rt, r & $r \varepsilon$ & TV,TY & (1) & أقوم بممارسة هواياتى الخاصة دون تدخل من احد & Y \\
\hline ru, r & $r \varepsilon$ & TV,T & (1) & يترك لى حرية التصرف لإنهاء أي خلاف بينى وبين إخوتى & $r v$ \\
\hline זr, & ro & ד & $\mathrm{v}$. & أحدد لنفسى إذا كنت أحتاج لمجموعات تقوية فى بعض المواد الدراسية & ra \\
\hline rq,.० & $\varepsilon$ & $7 ., 90$ & $T \varepsilon$ & أستطيع حل مشكلاتى بنفسى دون اللجوء الّى أحد & rq \\
\hline$\varepsilon \cdot, \cdot$ & $\varepsilon r$ & $7 \cdot, \cdots$ & זד & عندما تواجهنى مشكلة أحاول حلها بنفسى دون تدخل من أحد & r. \\
\hline$|V| \leq$, & 11 & $\wedge r, \wedge т$ & $\Lambda \vee$ & التوكنيىي أن أحسن عرض وجه نظري التى تخالف ما يراه الآخرين & 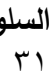 \\
\hline$r \cdot, \ldots$ & r) & $\wedge \cdot, \cdots$ & $\wedge \varepsilon$ & أَدافع عن نغسى إذا وجه شخص أكبر منى نقداً أو إهانة لى & rt \\
\hline$r \cdot, \ldots$ & r) & $\wedge \cdot, \cdot$ & $\wedge \varepsilon$ & أتراجع عن وجه نظري إذا اكتشفت عدم صحتها & سب \\
\hline$r \cdot$, rA & r & $79,0 \mathrm{r}$ & $\mathrm{vr}$ & أعتذر علناً لزميل عن خطا ارتكبته في حقه & $r \varepsilon$ \\
\hline
\end{tabular}




\begin{tabular}{|c|c|c|c|c|}
\hline \multicolumn{2}{|c|}{ ע } & \multicolumn{2}{|c|}{ نعم } & \multirow[b]{2}{*}{ 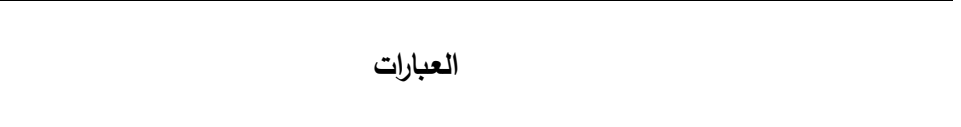 } \\
\hline$\%$ & 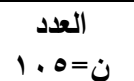 & $\%$ & 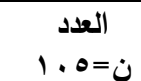 & \\
\hline$\varepsilon \cdot, \cdots$ & $\varepsilon r$ & $7 \cdot, \ldots$ & Tr & أطالب صديقى بضرورة تعديل بعض جوانب سلوكه التى يستاء منها الآخرون \\
\hline$\{0, \vee 1$ & $\varepsilon \wedge$ & $0 \leqslant, Y q$ & ov & القيادية من السهل على إخبار أحد أصدقائى بخطأ ارتكبه فى حقى \\
\hline $19, .0$ & r. & $\wedge \cdot, 90$ & 10 & 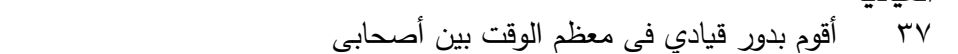 \\
\hline $19, .0$ & r. & $\Lambda \cdot, 90$ & 10 & يلجأ الى الأصدقاء عندما يريدون قراراً فى بعض أمورهم \\
\hline 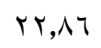 & $r \varepsilon$ & $\vee V, I \leq$ & $\wedge$ & شخصيتى تترك أثراً فى نفس زملائى وأصحابى \\
\hline$r r, \Lambda$ & ro & $v 7,19$ & $\wedge$. & لا أشعر بأي ارتباك اذا دخلت مكان وتوجهت أنظار الناس إلى \\
\hline$r \tau, T V$ & rA & 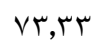 & VV & يمكننى أن أَتحدث بطلاقة أمام مجموعة من الأشخاص \\
\hline rA, OV & r. & $v 1, \varepsilon r$ & vo & العدوانية أحتفظ بأعصابى هادئة فى المواقف المثيرة للتوتر \\
\hline $7 r, \lambda$ & TV & $r 4,19$ & rᄉ & rع " من السهل على أن أقوم بمشاجرة باليدين مع أحد الأشخاص \\
\hline $90, v 1$ & 79 & $r \leq, r q$ & צ & لا أتردد فى أن أكثف عيوب الثخص أمام الآخرين \\
\hline TV,TY & (1) & r,r, & $r \varepsilon$ & أكون حاد الطبع في تصرفاتى \\
\hline$V \cdot, \varepsilon \wedge$ & $v \varepsilon$ & rq,० & ५ & إذا استفزنى أحد الأشخاص أشتمه وأضربه \\
\hline rr, & VV & $r \uparrow, T V$ & rᄉ & يحدث كثيراً أن أغضب وأفقد أعصابى \\
\hline$V 0, r \varepsilon$ & $\vee q$ & $r \leq, V T$ & r & 1العصابية إذا خاصمت شخص ما فأننى أتهكم عليه وأسخر منه أمام الآخرين \\
\hline$\wedge, 0 \mathrm{~V}$ & 9 & $91, \varepsilon$ & 97 & 9 ؛ " أشعر بالتعاسة دون سبب واضح \\
\hline 4., 19 & rA & Tr,八 & TV & نومى متقطع وغير مستقر \\
\hline$\varepsilon r, \wedge T$ & 纟o & $o v, 1 \leq$ & 7. & تضايقنى مشاعر النقص \\
\hline$\leqslant 9,0 \mathrm{r}$ & or & $0 ., \leqslant \Lambda$ & or & يؤذينى جدا أن يجد الناس فى عملى خطأ ما \\
\hline TV,T & (1) & אוז,ru & $\varepsilon r$ & أنا سريع الاستثارة والغضب \\
\hline \multirow[t]{19}{*}{$v 1, \varepsilon r$} & vo & rA,OV & $r$ r. & من السهل جدا جرح مشاعري \\
\hline & & & & داول 1 ا. توزيع درجات المبحوثين وفقاً لمستوى السمات الثخصية اله \\
\hline & $\%$ & & 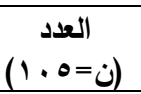 & 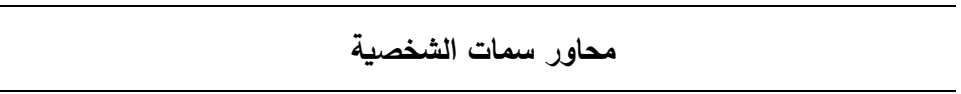 \\
\hline & & & & 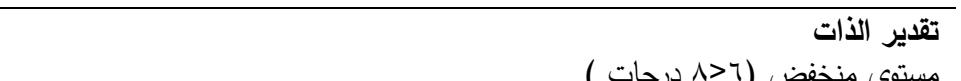 \\
\hline & $\begin{array}{l}1,0 V \\
10, Y \leqslant\end{array}$ & & $\begin{array}{l}9 \\
17\end{array}$ & مستوى متوسط منخفض (1>>> • 1 درجات ) ) \\
\hline & $V 4,19$ & & $\wedge$. & مستوى مرتفع (· الميولة درجات فاكثر ) \\
\hline & $r, \wedge$ & & $\varepsilon$ & مستوى منخفض (1>1 درجات ) \\
\hline & $9,0 \mathrm{r}$ & & 1. & مستوى متوسط (^>> . 1 درجات \\
\hline & $\wedge \uparrow, T \vee$ & & 91 & 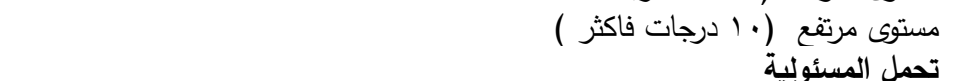 \\
\hline & $0, \times 1$ & & 7 & مستوى منخفض (1>1 درجات ) \\
\hline & r. & & r) & مستوى متوسط (^>>> • 1 درجات) \\
\hline & $V \leqslant, Y q$ & & vA & 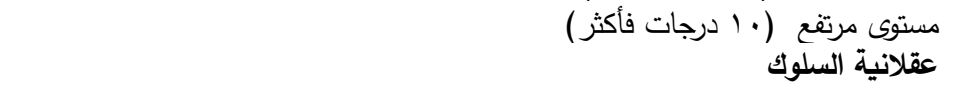 \\
\hline & $0, \times 1$ & & 7 & مستوى منخفض (>> درجات ) \\
\hline & $\mid \wedge, 1$. & & 19 & مستوى متوسط (^>> . . درجات) \\
\hline & $V 7,19$ & & $\wedge$. & مستوى مرتقع (· الاستقلية درجات فأكثر ) \\
\hline & r. & & r) & مستوى منخفض (>> درجات ) \\
\hline & $1 \leqslant, r q$ & & 10 & مستوى متوسط (^>> . 1 درجات) \\
\hline & $70, \mathrm{~V}$ & & 79 & السلوك التوكيدي ( • ( درجات فأكثر ) \\
\hline & 9,0 r & & 1. & مستوى منخفض (1>1 درجات ) \\
\hline
\end{tabular}




\begin{tabular}{|c|c|c|}
\hline$\%$ & 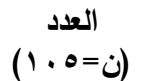 & محاور سمات الشخصية \\
\hline $19, .0$ & r. & مستوى متوسط (^> ـ ـ درجات) \\
\hline$v 1, \varepsilon r$ & vo & مستوى مرتفع (· ( درجات فأكثر ) \\
\hline $1 \cdot, \leqslant \wedge$ & 11 & مستوى" منخفض (9>v درجات ) \\
\hline rT, rA & $r \varepsilon$ & مستوى متوسط (9> 1 | درجة ) \\
\hline$o v, 1 \leq$ & 7. & العدوانية مرتفع ( ا' درجة فأكثر) \\
\hline$r$ r,At & 17 & مستوى مرتفع(7>>درجات) \\
\hline rq,० & $r \varepsilon$ & مستوى متوسط (1> ، 1 درجات ) \\
\hline$\varepsilon V, T r$ & 70 & العصتابية منخفض ( • ( درجات فأكثر ) \\
\hline $1 \wedge, 1$. & 19 & مستوى مرتفع (†> ^ درجات ) \\
\hline$\varepsilon V, T r$ & o. & مستوى متوسط (^>> ـ درجة فأكثر ) \\
\hline$r \leqslant, r q$ & 4 & المستوى منخفض العام للسمات الـ الثخصية فاكثر) \\
\hline $\mathrm{V}, \mathrm{Tr}$ & $\wedge$ & مستوى منخفض( ז >> . 1 درجة ) \\
\hline $00, r \leq$ & $0 \wedge$ & مستوى متوسط( •>>> 9 درجة ) ' \\
\hline$r v, 1 \leq$ & rq & مستوى مرتفع (179 درجة فأكثر) \\
\hline
\end{tabular}

الموهبة كمتغير تابع، فقد تبين أن المتغيرات المستقلة مجتمعة

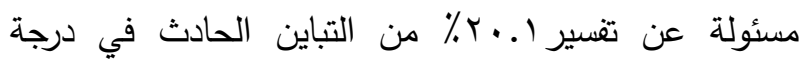
الموهبة وذلك وفقاً لقيمة معامل التحديد(R)، وهذه القيمة التهن

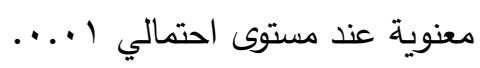
ولمعرفة أثر كل متغير من هذه المتغيرات على حده في

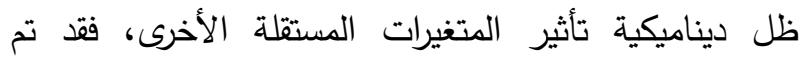
حساب معامل الانحدار الجزئي Partial Regression لكل منها كما هو موضـح في نفس الجدول والذي تشير نتائجه إلى

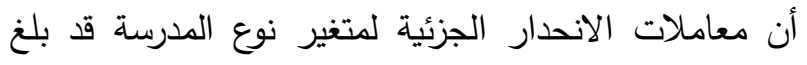

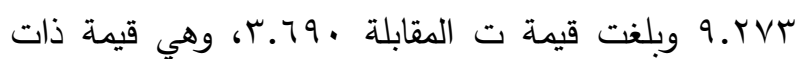
دلالة إحصائية عند المستوى الاحتمالي ا +.. ويشير ذلك إلى أنه كلما زادت الدرجة الدالة على نوع المدرسة بمقدار درجة واحدة تزداد بالتالي الدرجة الدالة على الموهبة بمقدار

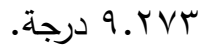

سادساً دراسة تأثير بعض المتغيرات المستقلة على مستوى كل من درجة الموهبة، ومستوى السمات الثخصية للمبحوثين كمتغيرين تابعين: - نتائج تحليل الانحدار المتعدد لاراسة تأثير بعض العوامل الأتية (الشخصية) كمتغيرات مستقلة على درجة الموهبة كمتغير تابع

أوضحت نتائج جدول (V) أنه عند تضمين الدرجات الدالة على العوامل الذاتية (الشخصية) للمراهقين الموهوبين (العمر - ترتيب الميلاد - الدرجة الدالة على نوع المدرسة - الدئ المستوى التعليمي - عدد الأنشطة الممارسة بقصر الثقافة العوامل الذاتية مجتمعة - ومستوى الإحباطات الثخصية) كتغيرات مستقلة في نموذج تحليلي واحد باستخدام دالة الانحدار المتعدد Multiple Regression المتغيرات المستقلة المدروسة والدرجة الكلية الدالة على درجة 
جدول V I. نتائج تحليل الانحدار المتعدد لتأثير بعض العوامل الذاتية (الشخصية) كمتغيرات مستقلة على درجة الموهبة كمتغير تابع

\begin{tabular}{|c|c|c|c|}
\hline مستوى المعنوية & قيمة (ت) & معامل الانحدار الجزئي & المتغيرات المستقلة \\
\hline$\cdots 1$ & T.MTK & rq.1.7 & ثابت الدالة \\
\hline ת .VTr & $. r \leqslant r$ & $\| r \leqslant q$ & العمر \\
\hline..$\vee \cdots$ & $\cdot$. М八T & $.0 \leq 7$ & ترتيب الميلاد \\
\hline$\ldots$. & r.79. & **a.rVr & الدرجة الدالة على نوع المدرسة \\
\hline. $.9 \vee Y$ & צחי... & $\ldots 9 \vee$ & المستوى التعليمى \\
\hline . & $. .199-$ & $\cdot . V \leqslant r-$ & عدد الأنشطة الممارسة بقصر الثقافة \\
\hline r & $. r \leq r$ & $\cdot r \leq q$ & العوامل الذاتية مجتمعة \\
\hline \multirow[t]{5}{*}{. .114} & $1.7 \ldots$ & .0 . 1 & مستوى الثعور بالإحباطات الثخصية \\
\hline & $\cdot . \leqslant \leqslant \wedge$ & & R (الارتباط المتعدد) R \\
\hline & $\cdot r \cdot r$ & & 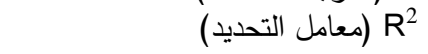 \\
\hline & .10 & & معامل التحديد المعدل \\
\hline & $* * 1.1 \cdot 1$ & & $\mathrm{~F}$ \\
\hline
\end{tabular}

الأم - المستوى الوظيفي للأب - المستوى الوظيفي للأم - إجمالي

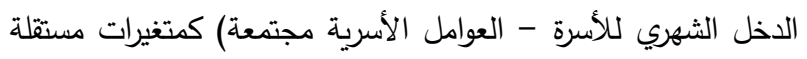

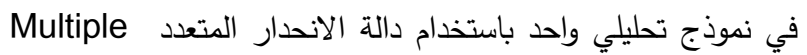
Regression الكلية الدالة على درجة الموهبة كمتغير تابع، فقد تبين أن المتغيرات

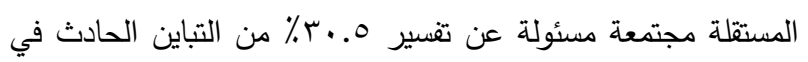

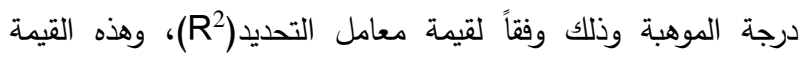
معنوية عند مستوى احتمالي ا.....
ץ- نتائج تحليل الانحدار المتعدد لتأثير بعض العوامل الأسرية كمتغيرات مستقلة على درجة الموهبة كمتفير تابع:

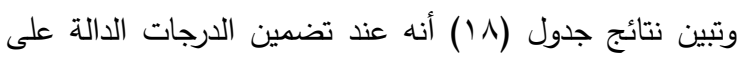
العوامل الأسرية للمراهقين الموهوبين (مستوى الممارسات الأسرية

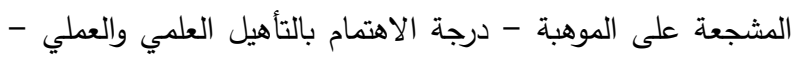
كيفية الاهتمام بالتأهيل العلمي والعملي - تأثير مكان النشأة - دالثيل

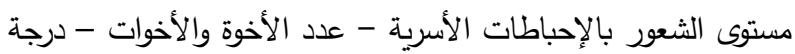
التزاحم الحجري - عمر الأم - مستوى تعليم الأب - مستوى تعليم

جدول 1 1. نتائج تحليل الانحدار المتعدد لتأثير بعض العوامل الأسرية كمتغيرات مستقلة على درجة الموهبة كمتغير تابع

\begin{tabular}{|c|c|c|c|}
\hline مستوى المعنوبة & قيمة (ت) & معامل الانعدار الجزئي & المتغيرات المستقلة \\
\hline 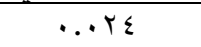 & r.r & r4.YII & 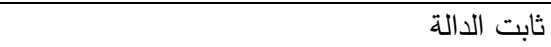 \\
\hline$\ldots v$. & $1 . \wedge r \varepsilon-$ & $. .001-$ & مستوى الممارسات الأسرية المشجعة على الموهبة \\
\hline$. .1 \leqslant 1$ & I. & $0 . \wedge \wedge$. & درجة الاهتمام بالتأهيل العلمى والعملى \\
\hline$\cdots \leqslant 9$ & $r \ldots r$ & *Y.OT & كيفية الاهتمام بالتأهيل العلمى والعملى \\
\hline . Aro & $. \cdot r \cdot 9-$ & . & تأثير مكان النشأة \\
\hline$\ldots r$ & r.. 10 & $* * .911$ & مستوى الثعور بالإحباطات الأسرية \\
\hline .18. & $1 . r \wedge \varepsilon-$ & $1 . \leqslant 94-$ & عدد الأخوة والأخوات \\
\hline .191 & $1 . r 9 \vee-$ & r.lor- & التزاحم الحجري \\
\hline .170 & $1 . \varepsilon \ldots-$ & $\cdot . \vee 17-$ & عمر الأم \\
\hline . TVA & $1 . .94$ & r.. . & مستوى تعليم الأب \\
\hline 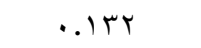 & $1.0 r r-$ & r.VAᄉ- & مستوى تعليم الأم \\
\hline$\cdot 1 \leq 7$ & $1 . \leqslant 77$ & $1 . V 1 \mathrm{~V}$ & المستوى الوظيفى للأب \\
\hline ..r & $r .1 \cdot 1-$ & $* 1 . .0 Y-$ & المستوى الوظيفى للأم \\
\hline$\cdots \cdot 1$ & r.sir & **s.ros & إجمالى الدخل الشهري للأسرة \\
\hline \multirow[t]{5}{*}{$\ldots \leqslant 0$} & $1.90 \mathrm{r}$ & $* . .011$ & العوامل الأسرية مجتمعة \\
\hline & $.00 r$ & & R (الارتباط الَّتعدد) R \\
\hline & 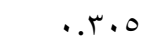 & & (معامل التحديد) R2 \\
\hline &. .IVA & & معامل التحديد المعدل \\
\hline & 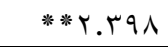 & & $\mathrm{F}$ \\
\hline
\end{tabular}


كما تثير النتائج أن معاملات الانحدار الجزئية لمتغيرات (مستوى الثعور بالإحباطات الأسرية، وإجمالي الإنيات

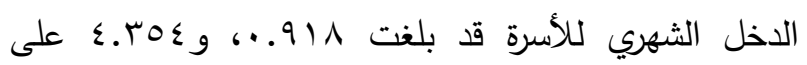

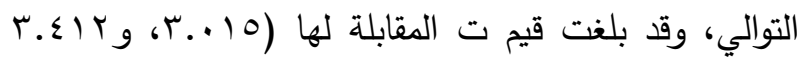
على التوالي) وكانت قيم معنوية عند مستوى احتمالي (....،

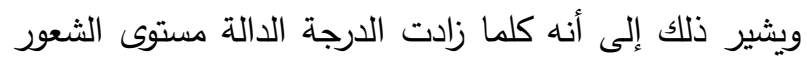

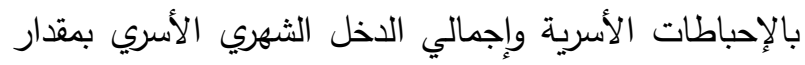

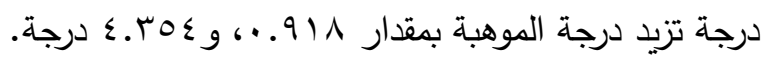
بناءً على ما سبق ومن خلال نتائج تحليل الانحدار المتعدد والذي هدف إلى دراسة تأثير العوامل الذاتية (الثخصية) والعوامل الأسرية كمتغيرات مستقلة على درجة

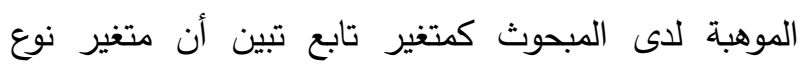

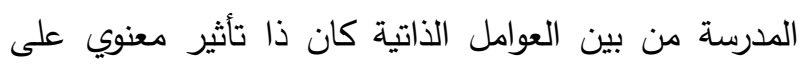
درجة الموهبة ويفسر ذلك بأنه كلما ارتقى مستوى المدرسة التي يتلقى فيها الموهوب تعليمه كلما زاد الاهتمام بموهبته

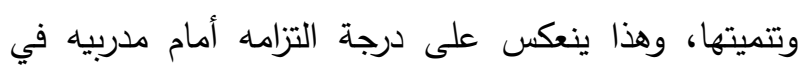
قصر الثقافة وبالتالي يرفع من مستوى حكمهم على موهبته. كما تبين أن الكيفية التي تهتم بها الأسرة بالتأهيل العلمي

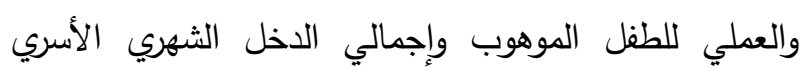

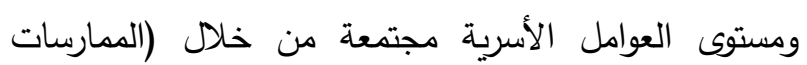

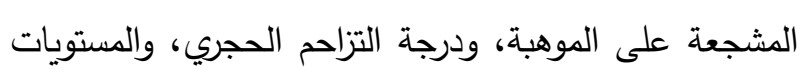

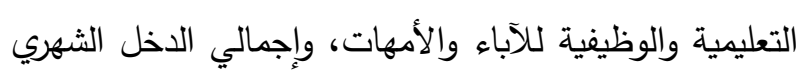

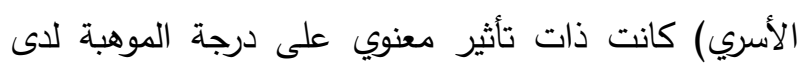

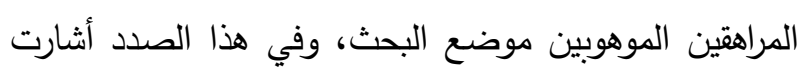

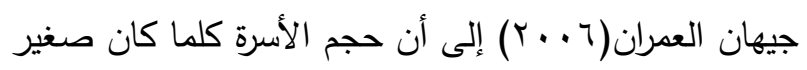

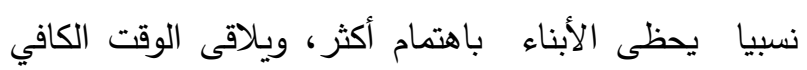

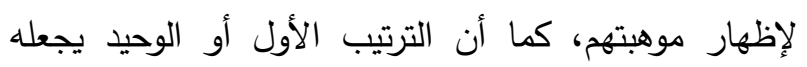
متمتع بمعاملة خاصة وهذا يثجعه على الاستقلالية والدور الإديل

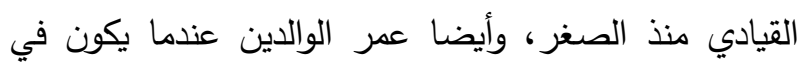
أواخر العشرينات وأوائل الثلاثين ينعكس إيجابيا على تتمية الثيا لئل
ولمعرفة أثر كل متغير من هذه المتغيرات على حده في

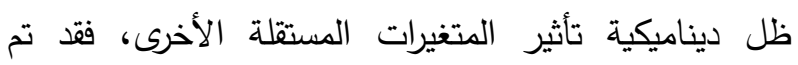

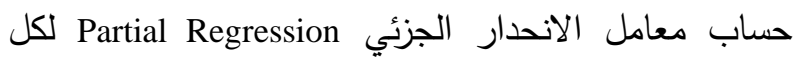
منها كما هو موضح في نفس الجدول والذي تثير نتائجه إلى أن معاملات الانحدار الجزئية لمتغيرات (كيفية الاهتمام

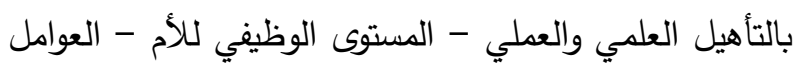

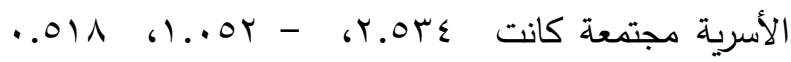

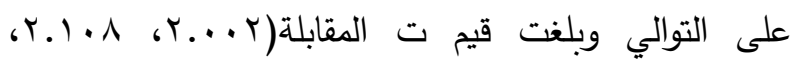
1.90r على التوالي) وهي قيم ذات دلالة إحصائية عند المستوى الاحتمالي ه...، بينما بلغت قيمة معاملات الانحدار الجزئية لمتغيرات (الإحباطات الأسرية، وإجمالي

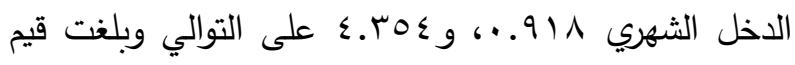

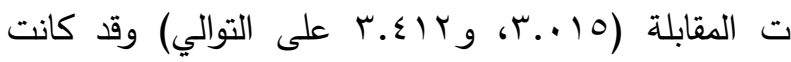
معنوية عند مستوى احتمالي ا... ويشير ذلك إلى أنه كلما زادت الدرجة الدالة على كيفية الاهتمام بالتأهيل العلمي العئي

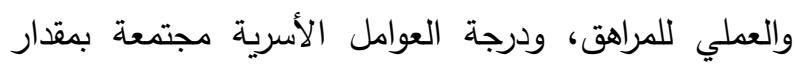
درجة واحدة تزداد بالتالي الدرجة الدالة على الموهبة

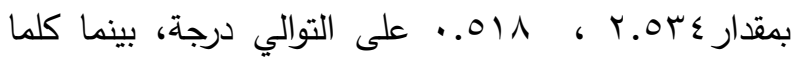

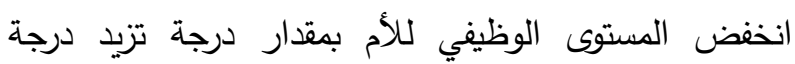

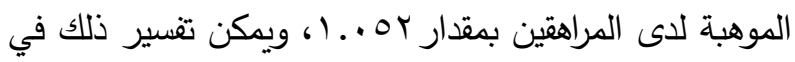
ضوء زيادة عدد أمهات المبحوثين من ربات الأسر واللاتي بلتي

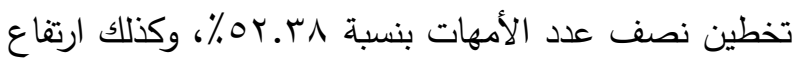
عدد المتعلمات منهن حيث كان ه. هو\% من الأمهات

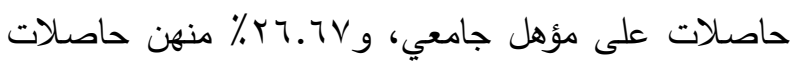
على الثانوية العامة أو ما يعادلها، مما يمكن الاستتناج مناته

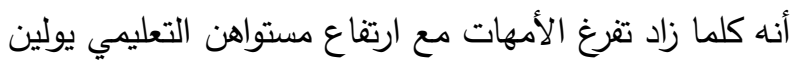

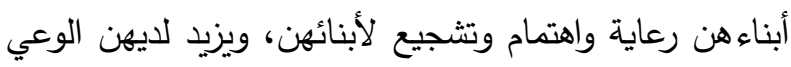
بأهمية الموهبة في تثكيل شخصية المراهق وتأثيرها الإيجابي على سواء شخصيته. 
تبين نتائج جدول (19) أنه عند تضمين الدرجات الدالة

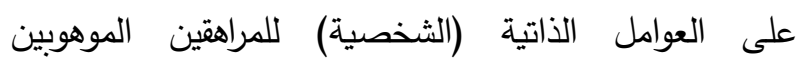

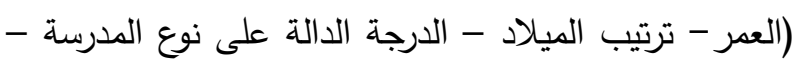

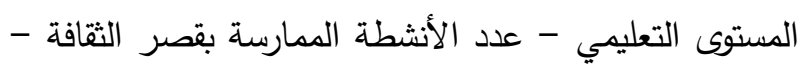
العوامل الذاتية مجتمعة - مستوى الثعور بالإحباطات الثخصية) كمتغيرات مستقلة في نموذج تحليلي واحد باستخدام دالة الانحدار المتعدد Multiple Regression للعلاقة بين المتغيرات المستقلة الددروسة والدرجة الكلية الدالة على الدئ

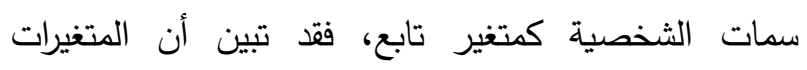

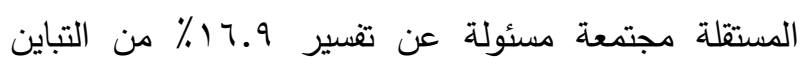
الحادث في سمات الثخصية وذلك وفقاً لقيمة معامل

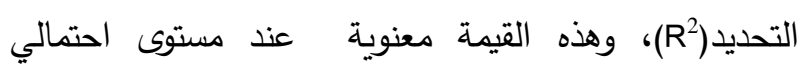
...

ولمعرفة أثر كل متغير من هذه المتغيرات على حده في

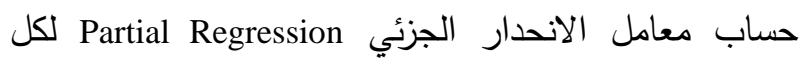

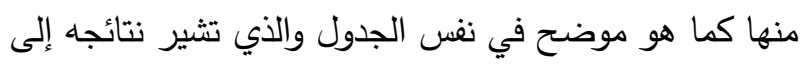

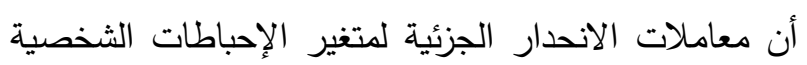

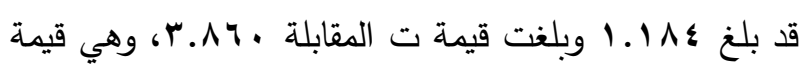
ذات دلالة إحصائية عند المستوى الاحتمالي ال....

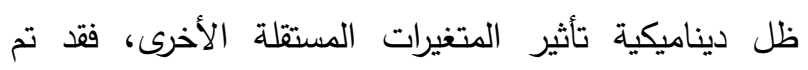

الموهبة الكامنة لدى ابنهم، كما أن وجود الوالدين بمراكز

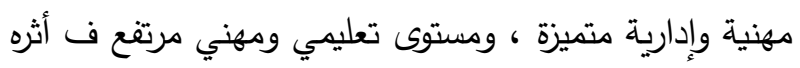

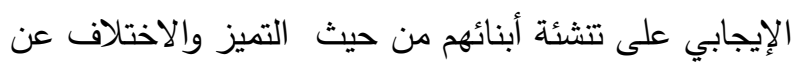

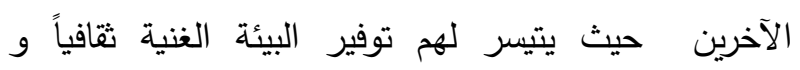
الملاعمة لإبراز مهاراتهم.

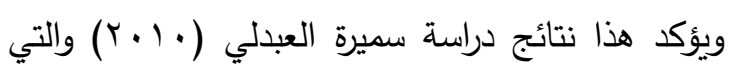
هدفت لمعرفة مستوى وعى الأسرة بدورها في رعاية الموهوب لئي

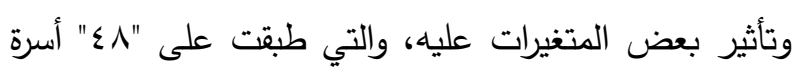

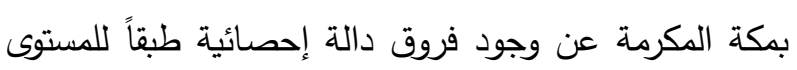

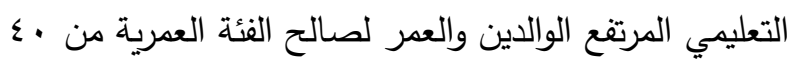

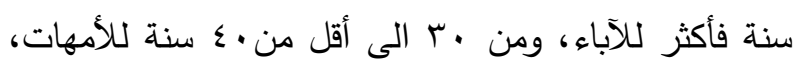
أما عدد أفراد الأسرة فكان لصالح الأسر الأقل من ؟ أفراد.

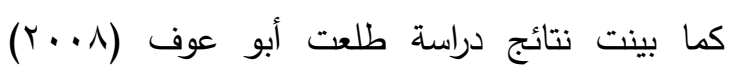

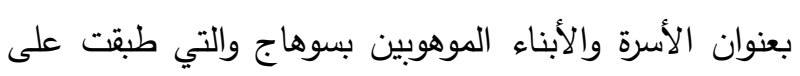

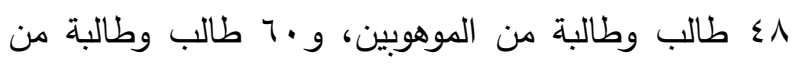
العاديين الى وجود علاقة دالة إحصائياً بين الموهبة وأبعاد المستوى الاجتماعي والاقتصادي للأسرة.

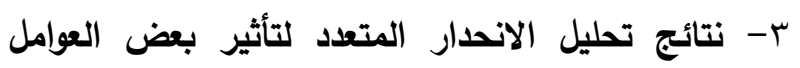
الذاتية (الثخصية) كمتغيرات مستقلة على درجة سمات الثخصية للمبحوثين كمتغير تابع جدول 9 ا. نتائج تحليل الانحدار المتعدد لتأثير بعض العضئ العوامل الذاتية (الثخصية) كمتغيرات مستقلة على درجة سمات

الثخصية للمبحوثين كمتغير تابع

\begin{tabular}{|c|c|c|c|}
\hline مستوى المعنوبـة & قيمة (ت) & معامل الانحدار الجزئي & المتغيرات المستقلة \\
\hline$\cdots \cdots$ & T.AY. & VY.乏.V & 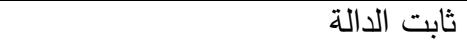 \\
\hline.$r l$. & 1.rTr &. . 1 rq & 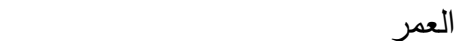 \\
\hline$\cdot . \wedge 1$. & $. r \leq 1-$ & . Y YO.- & ترتيب الميلاد \\
\hline.$r_{1}$. & I.YTY- & . To.- & الدرجة الدالة على نوع المدرسة \\
\hline $.0 \leq$. & $1.9 \leq 9-$ & Г.ศ7ร- & المستوى التعليمى \\
\hline.$Y \wedge \varepsilon$ & $1 . . V \vee-$ & - & عدد الأنشطة الممارسة بقصر التثافة \\
\hline$\cdot .7 \cdot \varepsilon$ & 1.rTr &.$\wedge r q$ & العوامل الذاتية مجتمعة \\
\hline \multirow[t]{5}{*}{$\cdots \cdots$} & ґ.Ат. & $* * 1.1 \wedge \varepsilon$ & مستوى الشعور بالإحباطات الشخصية \\
\hline & . . & & (الارتباط المتعدد) R R \\
\hline &. .179 & & (معامل التحديد) R2 \\
\hline &. .111 & & معامل التحديد المعدل \\
\hline & **T.MTV & & 1 \\
\hline
\end{tabular}


المدروسة والدرجة الكلية الدالة على السمات الثخصية للمراهقين الموهوبين كمتغير تابع، فقد تبين أن المتغيرات

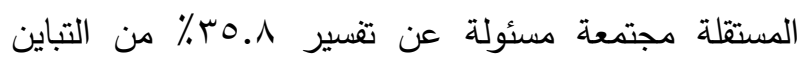
الحادث في درجة مستوى السمات الشخصية للمبحوث كتغير تابع وذلك وفقاً لقيمة معامل التحديد(R²)، وهذه القيمة معنوية عند مستوى احتمالي الب..... ولمعرفة أثر كل متغير من هذه المتغيرات على حده في ظل ديناميكية تأثير الدتغيرات المستقلة الأخرى، فقد تم حساب معامل الانحدار الجزئي Partial Regression لكل

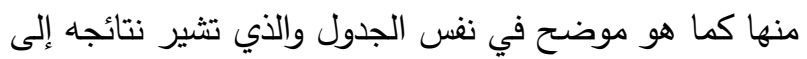

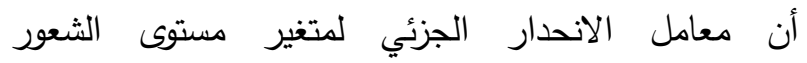
بالإحباطات الأسرية قد بلغ باءـ..، وبلغت قيمة ت المقابلة 197.19 وهي قيمة ذات دلالة إحصائية عند المستوى الاحتمالي 0....
ع- نتائج تحليل الانحدار المتعدد لتأثير بعض العوامل

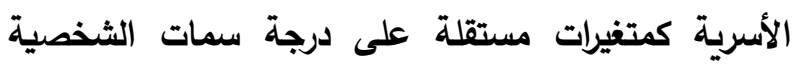
لمبحوثين كمتفير تابع يوضح جدول (·r) أنه بتضمين الدرجات الدالة على

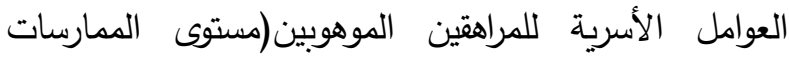
الأسرية المشجعة على الموهبة - درجة الاهتمام بالتأهيل

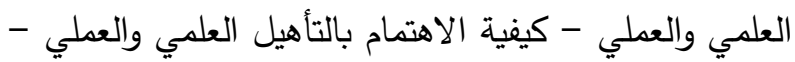
تأثير مكان النشأة - مستوى الثعور بالإحباطات الأسرية عدد الأخوة والأخوات - درجة التزاحم الحجري - عمر الأم

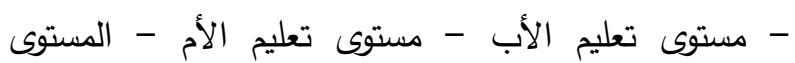
الوظيفي للأب - المستوى الوظيفي للأم - إجمالي الدخل

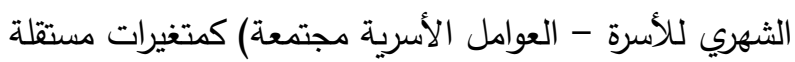
في نموذج تحليلي واحد باستخدام دالة الانحدار المتعدد Multiple Regression

جدول ·r. نتائج تحليل الانحار المتعدد لتأثير بعض العوامل الأسرية كمتغيرات مستقلة على درجة سمات الثخصية

\begin{tabular}{|c|c|c|c|}
\hline مستوى المعنوبة & قيمة (ت) & معامل الانحدار الجزئى & المتغيرات المستقلة \\
\hline$\cdots \cdots$ & $0 . . \varepsilon$. & $7 V . .0 Y$ & ثابت الدالة \\
\hline$\because \vee 9 \varepsilon$ &. rTr & $\cdot .7 V$ & مستوى الممارسات الأسرية المشجعة على الموهبة \\
\hline..$\Sigma q \mu$ & $. .7 \wedge \wedge-$ & r.rrq- & درجة الاهتمام بالتأهيل التعلمى والعملي \\
\hline .04. &. .74 & $.7 \vee 0$ & كيفية الاهتمام بالتأهيل العلمى والعملى \\
\hline$\cdot . \Sigma Y \leqslant$ & $\cdot . \Lambda \cdot r$ & I.Y. & تأثير مكان النشأة \\
\hline$\cdots \leqslant \Lambda$ & $1 . \vee 997$ & $* . . \leqslant 7 r$ & مستوى الثعور بالإحباطات الأسرية \\
\hline. ro. & 1.101 & $1.0 \leqslant$ & عدد الأخوة والآخوات \\
\hline..$I V A$ & $1 . r o v$ & $1.9 \cdot r$ & درجة التزاحم الحجري \\
\hline.$Y Y q$ & I.YIT- & $. .0 Y \leqslant-$ & 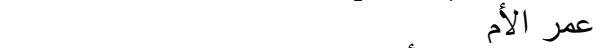 \\
\hline $.0 \leq 9$ & $\cdot .7 \cdot r$ & .971 & مستوى تعليم الأب \\
\hline ع & $.9 \vee r$ & $1.0 . r$ & مستوى تعليم الأم \\
\hline.$A T V$ & $. T^{\prime}-$ & $. . Y I V-$ & المستوى الوظيفى للأب \\
\hline$\cdot 1 \leq$. & $1.291-$ & $. .7 \Upsilon \wedge-$ & المستوى الوظيفى للأم \\
\hline. $.11 \mathrm{~V}$ & $1.01 \varepsilon$ & $1 . V \cdot V$ & إجمالى الدخل الثهري للأسرة \\
\hline \multirow[t]{5}{*}{ 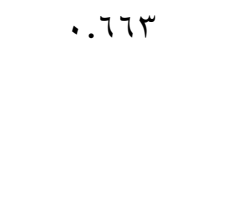 } & $\cdot . \leqslant$. &. .991 & العوامل الأسرية مجتمعة \\
\hline &. .099 & & R (الارتباط الَّتعدد) R \\
\hline &.$r O \Lambda$ & & (معامل التحديد) R2 \\
\hline & $. r \leq 1$ & & معامل التحديد المعدل \\
\hline & $* * \Gamma .00$ & & $\mathrm{~F}$ \\
\hline
\end{tabular}


حساسية الموهوبين الانفعالية للمشكلات الاجتماعية ومعاناتهم من الاغتراب والضغوط أكثر من أقرانهم.

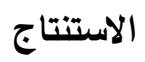

من واقع دراسة الخصائص الذاتية (الثخصية) والأسرية للمراهقين الموهوبين المترددين على قصري ثقافة الثاطبي والأنفوشي بالإسكندرية، والتعرف على أسباب الإحباطات

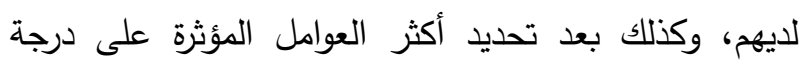

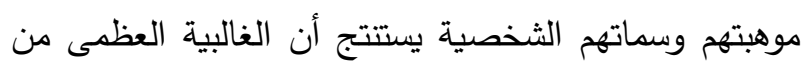
أسر المبحوثين كان مستوى مساهماتهم الأسرية محفزة للموهبة بدرجة مرتفعة أو متوسطة، وأكثر من نصف عدد الموهوبين المشاركين في الدراسة لديهم شعور بالإحباطات الثخصية والأسرية بدرجة مرتفعة ومتوسطة، وبتقييم درجة الموهبة لدى المبحوثين من خلال الخصائص السلوكية لديهم تبين أن غالبية المبحوثين يتمتعون بدرجة متوسطة إلى لى لئ مرتفعة من الموهبة، وبدراسة السمات الثخصية المميزة لهذه الفئة من المراهقين الموهوبين أظهرت النتائج أن غالبية وندية المبحوثين لديهم مستوى مرتفع من تقدير الذات، والميول الاجتماعية وتحمل المسئولية وعقلانية السلوك، وأكثر من من فئنئن نصف العينة كان لديهم مستوى مرتفع من الاستقلالية والخصائص القيادية. من نتائج تحليل الانحدار المتعدد تبين أن المتغيرات الذاتية (الثخصية) والأسرية المستقلة المؤثرة معنوياً على درجة الموهبة كمتغير تابع كانت لمتغيرات (نوع ولتيرات المدرسة، ومستوى الثعور بالإحباطات الأسرية، وإجمالي

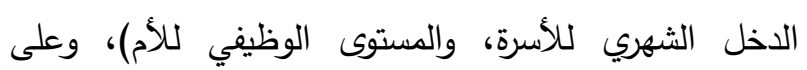
الجانب الآخر تبين أن المتغيرات الذاتية (الشخصية) والأسرية

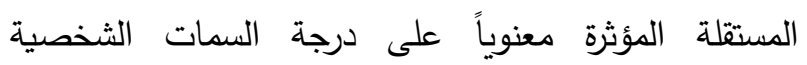
للمبحوثين كمتغير تابع كانت الإحباطات الشخصية والأسرية.

\section{التوصيات}

ا.توعية أفراد الأسرة بطرق اكتشاف الموهبة لدى أبنائهم وسبل تتميتها، والعمل على إثباع حاجاتهم، وتثجيعهم
بناءً على ما سبق ومن خلال نتائج تحليل الانحدار المتعدد والذي هدف إلى دراسة تأثير العوامل الذاتية (الثخصية) والعوامل الأسرية كمتغيرات مستقلة على درجة سمات الثخصية للمبحوثين كمتغير تابع يتضح أن التأثير المعنوي على درجة سمات الشخصية المميزة للمبحوث جاء من خلال مستوى الثعور بالإحباطات الثخصية ومستوى دورى الثعور بالإحباطات الأسرية اللذين يعكسا ترجمة للحالة الانفعالية التي يشعر بها معظم الموهوبين تجاه المشاكل،

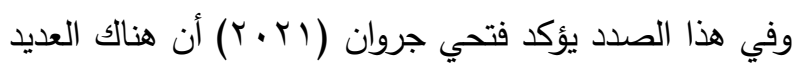
من المشكلات التي تواجه الموهوبين المراهقين نتيجة للتفاعل بين خصائصهم الثخصية وبيئته الأسرية والاجتماعية، ومعظم هذه المشكلات ذات طابع انفعالي تتعلق بتكيف الموهوب مع نفسه ومع الآخرين، أو مشكلات داخل نطاق الأسرة تتعلق بالتتشئة الأسرية التي تواجه الموهوبين. كما يرى عبد الله العمري (ع ا ـ r) أنه من أهم المعوقات التي تؤثر سلباً على انفعالات الموهوبين المراهقين بالأسرة والتي تشعرهم بالإحباط والقلق تتتج عن نقص خبرة الوالدين

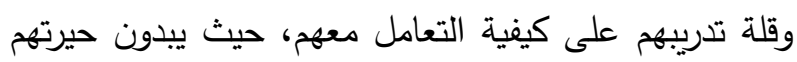
هل هم راشدين أم أطفال مما يشعرهم بسلبية الأساليب التي يعاملونهم بها فيواجهون مشاكل متعددة. وأيضاً من المشكلات الأسرية التي تواجه الموهوب نقص خبرة الوالدين بخصائصه السلوكية وضغوطهم تجاهه ليسرع من التعلم، والمعاملة غير السوية وإشعاره بالعجز وأن قرارته غير صحيحة، وعدم إثباع حاجاته، كذلك تدنى المستوى الاجتماعي والاقتصادي والثقافي للأسرة. وقلة وسائل الدعم وتوفر الجو العائلي الداعم والمشجع للموهبة

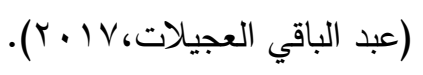

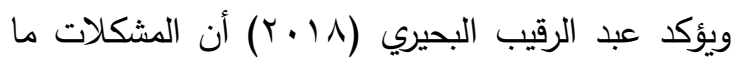
هي سوى معوقات تواجه الفرد وتحول بينه وبين تحقيق

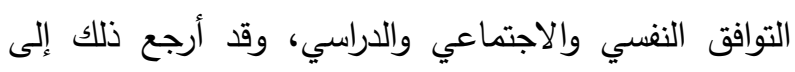




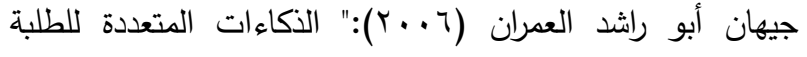

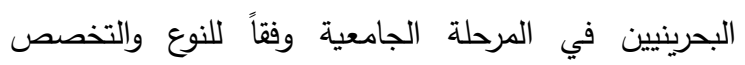

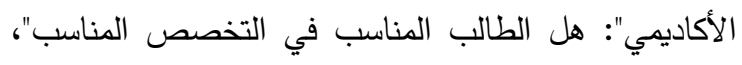

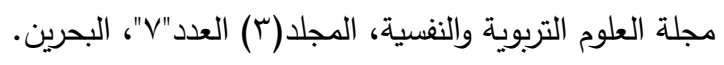

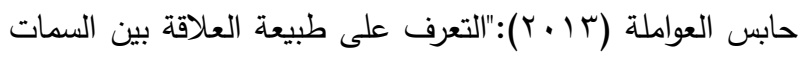

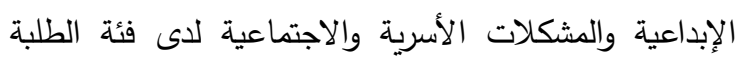
الموهوبين والعاديين في الصف العاشر في مدينة السلط"،

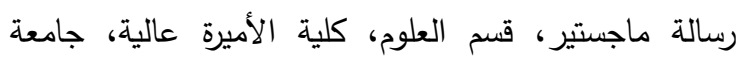

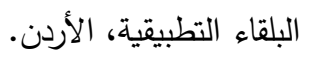

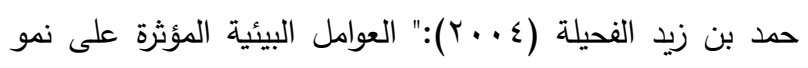

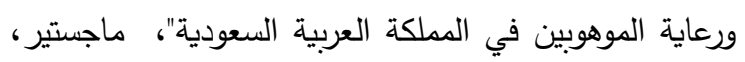
معهد الدراسات والبحوث البيئية، جامعة عين شمس.

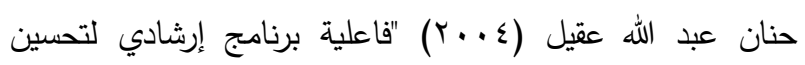
بعض المهارات الاجتماعية للفتيات الموهوبات المراهقات في بعاتي

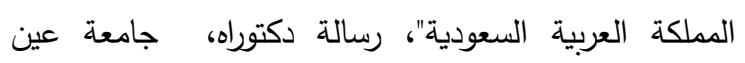
شمس.

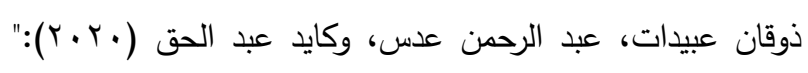

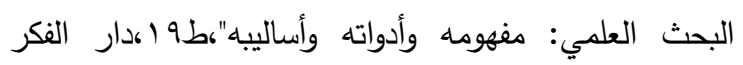
للطباعة والنشر والتوزيع.

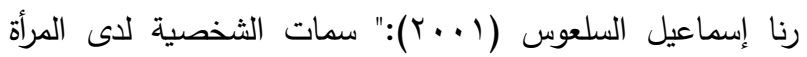

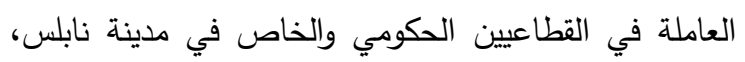
رسالة ماجستير ، جامعة النجاح الوطنية، نابلس، فلسطين.

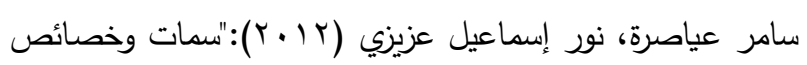

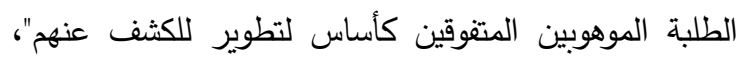

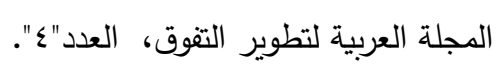

سامر محمد ماجد حامد (r . . r):" السمات الثخصية -العقليةلاى طلبة جامعة النجاح الوطنية وعلاقتها ببعض المتغيرات

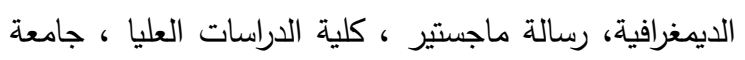

$$
\text { النجاح الوطنية ، نابلس، فلسطين. }
$$

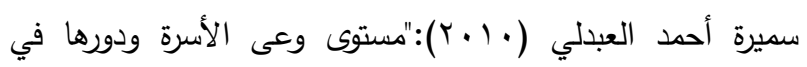
رعاية الطفل الموهوب"، مجلة بحوث التربية النفسية، جامعة المبل

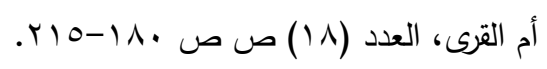

على الاستعانة بالوسائل التكنولوجية الحديثة في تتمية موهبتهم. r. التواصل بين الأسرة والمراكز المتخصصة برعاية الموهبة لإثراء موهبة الطفل وتتمية قدراته.

r. إعداد دليل شامل للأسرة فيه كافة المعلومات اللازمة حول ولنيه قلئه اكتثاف الطفل الموهوب وطرق التعامل معه وإشباع احتياجاته ومواجهة إحباطاته.

ع. التوسع في إنشاء المزيد من الخدمات المجتمعية الموجهة لرعاية الموهوبين، مع الأخذ في الاعتبار بأهمية تتوع أنشطتها لتغطية كافة أشكال الموهبة. ه. إنشاء قاعدة بيانات قومية تضم الموهوبين، لتقدم لهم الاعم المتكامل من خلال برامج يشارك فيها كل من

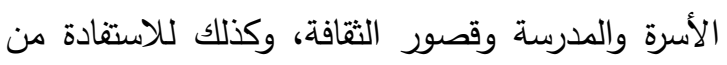

$$
\text { هؤلاء الموهوبين كثروة بشرية. }
$$

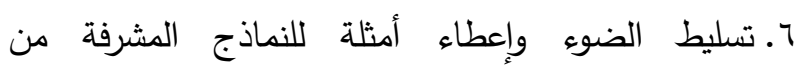
الموهوبين في وسائل الإعلام، ووسائل التواصل الاجتماعي، والمؤسسات التعليمية، والمؤسسات الاجتماعية.

V. إعداد برامج تدرببية للتنمية الذاتية للموهوبين. ^. إثراء هذا المجال بالمزيد من الدراسات والبحوث العلمية التي من شأنها توضيح الكثير من الحقائق نحو هذه

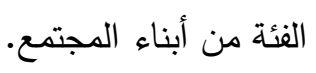

\section{المراجح}

أحمد محمد عبد الخالق، بدر محمد والأنصاري (799 (1)):"العوامل الخمسة الكبرى في مجال الثخصية" - مجلة علم النفس،

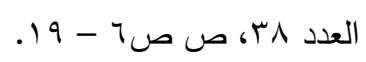

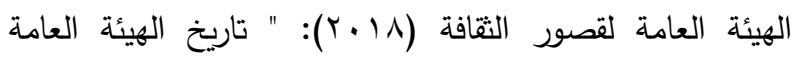
لقصور الثقافة " - متاح على الموقع الإليكتروني .www.gocp.gov.eg 


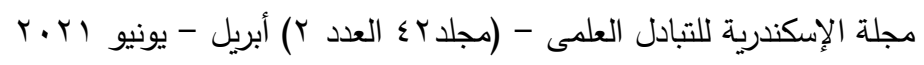

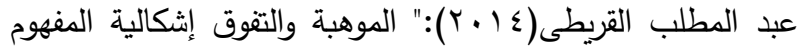

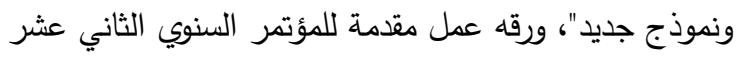
للمركز العربي للتعليم والتتمية، يوليو، القاهرة، مصر . فاروق الروسان، يوسف قطامي، وليد البطش (9. . ب): "أساليب

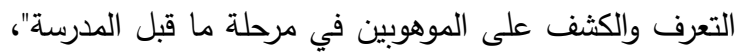

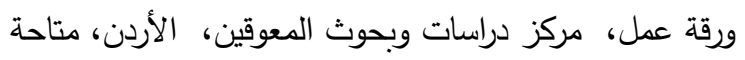
على الموقع.www.gulfkids/com

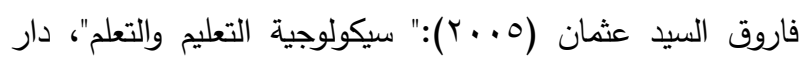

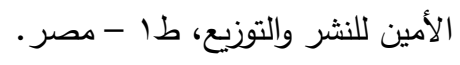
فتحي عبد الرحمن جروان (Y.Y.Y) :"الموهبة والتفوق" - عمان الأردن، دار الفكر، ناشرون وموزعون.

فتحية مقحوت (ع ( ب) :"أساليب المعاملة الوالدية للمراهقين

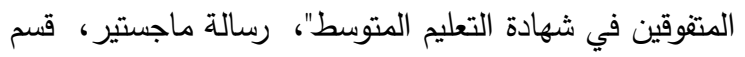

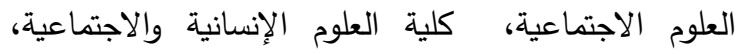

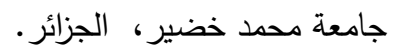

كاظم عبد نور عبد زيد، صباح فيصل حمزة (10 +r): " الخصائص السلوكية لدى طلبة الجامعة المتفوقين وأقرانهم العاديين في منطقة الفرات الأوسط" مجلة كلية التربية الأساسية للعلوم التربوية والإنسانية - جامعة بابل العدئ

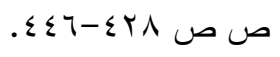

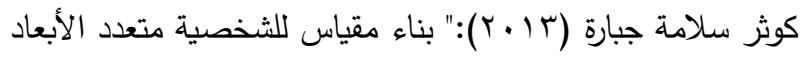
والتحقق من فاعليته في التتبؤ بالتحصيل الأكاديمي في كليات الطب والهندسة والحقوق"، مجلة الجامعة الإسلامية للدراسات التربوية والنفسية، المجلد الحادي والعشرون، العدد الثالث،

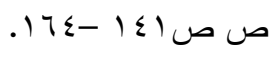

ليلى عبد الرحمن عبد العظيم كرار(؟ . ب):" بعض سمات المتفوقين عقلياً ومعايير كثفها في المدارس النموذجية بولاية الخرطوم ،"، رسالة دكتوراة، كلية الدراسات العليا، جامعة

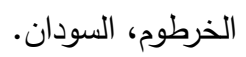
مايرز بريجز (Y.lV) :"اختبار أنماط الشخصية"، ترجمة ونشر

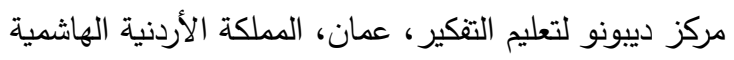

سهام على طه ، أمينة محمد عثمان (19 (Y) : "الأطفال الموهوبون" - طا - دار النشر الدولي - الرياض - المملكة

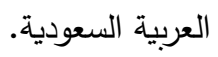

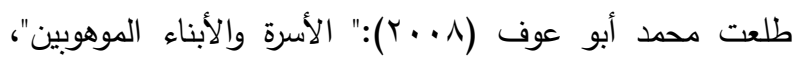
طا، قسم علم النفس التربوي، كلية التربية، جامعة سوهاج، العلم والإيمان للنشر والتوزيع. عاصم محمود الحيتانى (r ( ب):"الثباب الموهوبون وكيفية

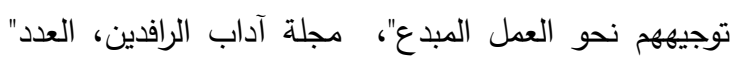
1)

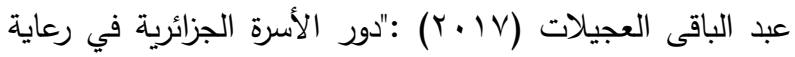

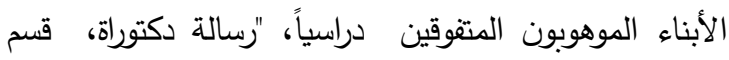
علم الاجتماع، كلية العلوم الإنسانية والاجتماعية، جامعة لدونة محمد دعابثين، سطيف، الجزائر.

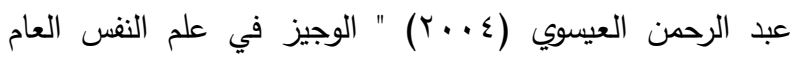

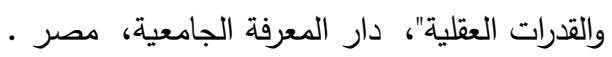

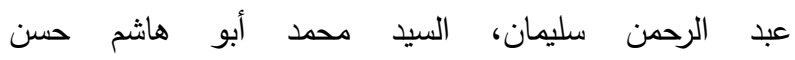

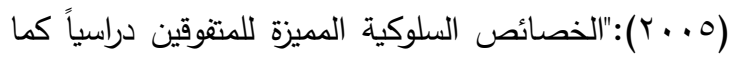
يدركها المعلمون والمعلمات بمراحل التعليم العام، مجلة

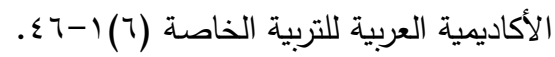
عبد الرقيب البحيري (1 ( • ب):تربية الموهوبين في مرحلة رياض الأطفال" مكتبة الأنجلو، القاهرة.

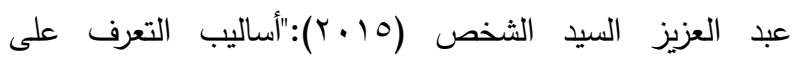
المتفوقين عقلياً والموهوبين ورعايتهم وتتمية قدراتهم الابتكارية "، المؤتمر الدولي الثاني للموهوبين والمتفوقين - تحت شعار -

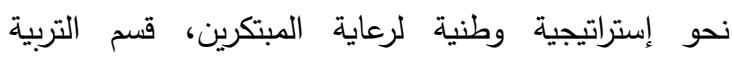

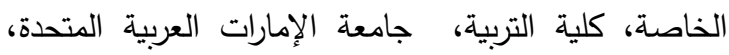
•

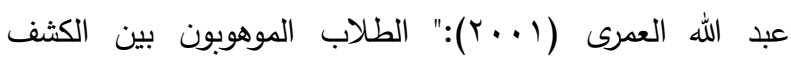
والرعاية"، إدارة التعلم بمحافظة المخواة، المملكة العربية السعودية. عبد الله الغامدي (Y Y • r):" أنواع النشاط الرياضي البدني "متاح على الموقعwww.ragocad/lip/nubras 
مواهب إبراهيم عياد، نيفين مصطفى حافظ، هدى محمد خليل

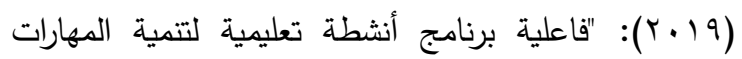

اللغوية والانتباه لاى أطفال الروضـة للتذخل المبكر والحد من

ظهور صعوبات التعلم" - مؤتمر التربية الخاصة وصعوبات

$$
\text { التعلم - جدة - المملكة العربية السعودية. }
$$

Chan, David W. (2006): "Emotional Intelligence and Components of Burnout among Chinese Secondary School Teacher in Hong Kong" Teaching \& Teacher Education 22(8), 1042-1054.

Eysenck, H. J., \& Eysenck, S. B. G. (1975). Manual of the Eysenck Personality Questionnaire (Junior and Adult). Hodder \& Stoughton, Kent, UK.

Holt L. (2016):"Positive Youth Development through Sport" 2nd edition, Routledge, UK.

Renzulli,J.S, Siegle,D., Ries,SM, G,avin, M,K \& Read,R. (2009): "An investigation of the Reliability and Factor structure of Four New Scales for Rating the Behavioral Characteristics of Superior Students", journal of Advanced Academics, 21,84-108.

Smyth E. \& Ross J. (1999):” Developing Leadership Skills of Pre-Adolescent Gifted Learners in Small Group Setting”, Gifted Child Quarterly, Vol.43 (3), pp. 204-211.

Sternberg, R. (2005):" WICS: A model of giftedness in leadership". Roeper Review. (28) 37-44.

WHO (2020) : “Adolescent Mental Health" , Available at www.who.int.

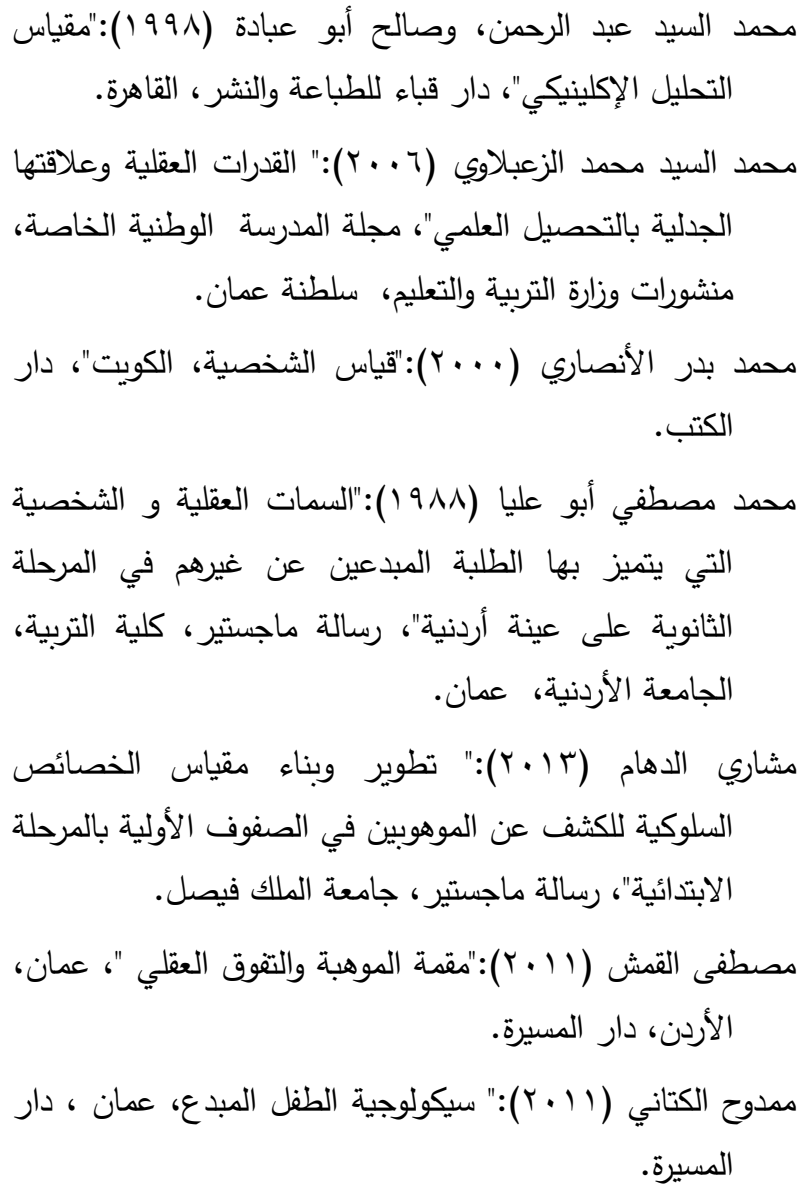




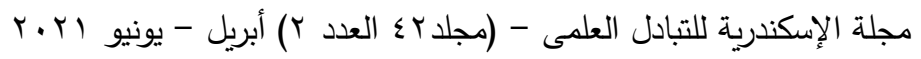

\title{
ABSTRACT \\ Self and Family Factors of Talented Teens Who Attend to Some Cultural Palaces in Alexandria and its Effect on Their Talent Degree and Their Personal Characteristics
}

\author{
Neven Mostafa Hafez, Mawaheb Ibrahim Ayad, Ahmed Samir Abou- Donia and
}

\section{Nahed Mohamed Al-Rahmany}

The real wealth of nations emerges from their ability to develop the natural abilities of their sons, and benefit from them. Talented members of society are the leaders of the development procession, especially in the era of current knowledge and technical revolution. From this point, this research aims mainly to study the personal and familial factors of a sample of talented adolescents who attend some cultural palaces in Alexandria, and its effect on the degree of their talent and their personal characteristics. To achieve this goal, a questionnaire was constructed to identify personal and family factors of the respondents, and two scales were built. One of which was to measure degree of talent based on the evaluation of the trainers and the other was to measure personal characteristics of the respondents. The study sample included the Anfoushi and Shatby palaces of culture. A sample of talented adolescents enrolled in activities within those palaces was selected, totaling 105 respondents. Descriptive-analytical approach was used in the study, and SPSS version 26 was used to perform the statistical transactions.

Results showed that most talented teens who attended palaces of culture were males, by $64.76 \%$ of the sample. The mean of their ages was $15.74 \pm 2.50$ years. The vast majority were enrolled in government schools by $80.95 \%$. $60.95 \%$ of respondents' fathers and $59.05 \%$ of respondents' mothers have a university education qualification. $52.38 \%$ of the mothers were housewives. Vast majority of respondents' families $80.0 \%$ followed a high or medium degree level of family encouragement of the talents of their sons. The results revealed that more than half of the talented respondents have a feeling of personal frustrations in a high and medium degree, by $21.90 \%$ and $34.29 \%$, respectively, and they have a feeling of high and medium family frustrations at similar rates, by $27.62 \%$ for each. $55.24 \%, 22.86 \%$ of the respondents have a moderate or high degree of talent respectively according to the evaluation of their trainers. The evaluation depended on their behavioral characteristics. Also, results showed that most of the respondents $76.19 \%$ have a high level of self-esteem and a high level of social tendencies, responsibility, and rationality of behavior by $86.67 \%, 74.29 \%$, and $67.19 \%$ respectively. More than half of the sample had a high level of independence and leadership characteristics by $65.71 \%$ and $57.14 \%$, respectively. The results of multiple regression analysis showed that the school type, family frustrations, total monthly income, and the mother's employment level as independent variables had a significant effect on the degree of talent as a dependent variable. On the other hand, it was found that personal and family frustrations had a significant effect on the degree of the respondents' personality characteristics as a dependent variable. The study recommends exerting more efforts to discover and care for talent through family and society for adolescents, in appreciation of the importance of talent and keenness to invest this age.

Keywords: talented teens - adolescents - cultural palaces - talent development and care 